\title{
Oxygen Isotope Trajectories of Crystallizing Melts: Insights from Modeling and the Plutonic Record
}

Claire E. Bucholz ${ }^{\mathrm{a}, \mathrm{b} *}$, Oliver Jagoutz ${ }^{\mathrm{a}}$, Jill A. VanTongeren ${ }^{\mathrm{c}}$, Jacob Setera $^{\mathrm{c}}$, and Zhengrong Wang ${ }^{\mathrm{d}}$

${ }^{a}$ Department of Earth, Atmospheric, and Planetary Sciences, Massachusetts Institute of Technology, 77 Massachusetts Avenue, Cambridge, MA 02139, USA

${ }^{b}$ Division of Geologic and Planetary Sciences, California Insititute of Technology, 1200 E. California Blvd., Pasadena, CA 91125, USA

${ }^{c}$ Department of Earth and Planetary Sciences, Rutgers University, 610 Taylor Road, Piscataway, NJ 08854, USA

${ }^{\mathrm{d}}$ Department of Earth and Atmospheric Sciences, City College of New York, CUNY, 160 Convent Avenue, New York, NY 10031

*Corresponding author. cbucholz@ caltech.edu

Email addresses: cbucholz@ caltech.edu (C. E. Bucholz), jagoutz@mit.edu (O. Jagoutz), jvantongeren@eps.rutgers.edu (J. A. VanTongeren), jacob.setera@ rutgers.edu (J. Setera), zwang1@ccny.cuny.edu (Z. Wang) 


\section{Abstract}

Elevated oxygen isotope values in igneous rocks are often used to fingerprint supracrustal alteration or assimilation of material that once resided near the surface of the earth. The $\delta^{18} \mathrm{O}$ value of a melt, however, can also increase through closed-system fractional crystallization. In order to quantify the change in melt $\delta^{18} \mathrm{O}$ due to crystallization, we develop a detailed closed-system fractional crystallization mass balance model and apply it to six experimentally- and naturally-determined liquid lines of descent (LLDs), which cover nearly complete crystallization intervals (melt fractions of 1 to $<0.1$ ). The studied LLDs vary from anhydrous tholeiitic basalts to hydrous high-K and calc-alkaline basalts and are characterized by distinct melt temperature- $\mathrm{SiO}_{2}$ trajectories, as well as, crystallizing phase relationships . Our model results demonstrate that melt fraction-temperature- $\mathrm{SiO}_{2}$ relationships of crystallizing melts, which are strongly a function of magmatic water content, will control the specific $\delta^{18} \mathrm{O}$ path of a crystallizing melt. Hydrous melts, typical of subduction zones, undergo larger increases in $\delta^{18} \mathrm{O}$ during early stages of crystallization due to their lower magmatic temperatures, greater initial increases in $\mathrm{SiO}_{2}$ content, and high temperature stability of low $\delta^{18} \mathrm{O}$ phases, such as oxides, amphibole, and anorthitic plagioclase (versus albite). Conversely, relatively dry, tholeiitic melts only experience significant increases in $\delta^{18} \mathrm{O}$ at degrees of crystallization greater than $80 \%$. Total calculated increases in melt $\delta^{18} \mathrm{O}$ of 1.0 to $1.5 \%$ can be attributed to crystallization from $\sim 50$ to $70 \mathrm{wt} . \% \mathrm{SiO}_{2}$ for modeled closed-system crystallizing melt compositions. As an example application, we compare our closed system model results to oxygen isotope mineral data from two natural plutonic sequences, a relatively dry, tholeiitic sequence from the Upper and Upper Main Zones (UUMZ) of the Bushveld Complex (South Africa) and a high-K, hydrous sequence from the arc-related Dariv Igneous Complex (Mongolia). These two sequences were chosen as their major and trace element compositions appear to have been predominantly controlled by closed-system fractional crystallization and their LLDs have been modeled in detail. We calculated equilibrium melt $\delta^{18} \mathrm{O}$ values using the measured mineral $\delta^{18} \mathrm{O}$ values and calculated mineral-melt fractionation factors. Increases of $2-3 \%$ and $1-1.5 \%$ in the equilibrium melts are observed for the Dariv Igneous Complex and the UUMZ of the Bushveld Complex, respectively. Closed-system fractional crystallization model results reproduce the $1 \%$ increase observed in the equilibrium melt $\delta^{18} \mathrm{O}$ for the Bushveld UUMZ, whereas for the Dariv Igneous Complex assimilation of high $\delta^{18} \mathrm{O}$ material is necessary to account for the increase in melt $\delta^{18} \mathrm{O}$ values. Assimilation of evolved supracrustal material is also confirmed with $\mathrm{Sr}$ and $\mathrm{Nd}$ isotope analyses of clinopyroxene from the sequence. Beginning with a range of mantle-derived basalt $\delta^{18} \mathrm{O}$ values of 5.7\%o ("pristine" mantle) to $\sim 7.0 \%$ (heavily subductioninfluenced mantle), our model results demonstrated that high-silica melts (i.e. granites) with $\delta^{18} \mathrm{O}$ of up to $8.5 \%$ can be produced through fractional crystallization alone. Lastly, we model the zircon-melt $\delta^{18} \mathrm{O}$ fractionations of different LLDs, emphasizing their dependence on the specific $\mathrm{SiO}_{2}-\mathrm{T}$ relationships of a given crystallizing melt. Wet, relatively cool granitic melts will have larger zircon-melt fractionations, 
potentially by $\sim 1.5 \%$, compared to hot, dry granites. Therefore, it is critical to constrain zircon-melt fractionations specific to a system of interest when using zircon $\delta^{18} \mathrm{O}$ values to calculate melt $\delta^{18} \mathrm{O}$.

\section{INTRODUCTION}

As oxygen is the most abundant element in the silicate Earth, oxygen isotopes are a powerful and widely used tool to study the source and magmatic evolution of igneous rocks. In particular, $\delta^{18} \mathrm{O}$ values of igneous rocks and minerals can yield information about the degree of mantle versus crustal material involved in their origin (e.g. James, 1981). For example, mafic igneous rocks enriched in ${ }^{18} \mathrm{O}$ compared to basalts from mid-ocean ridges $\left(\delta^{18} \mathrm{O}^{1}=5.7 \pm 0.2 \%\right.$ ) must have interacted with material that resided on or near the surface of the earth, either through contamination of the mantle by subduction of surface materials or through direct assimilation in the crust (Magartiz et al., 1978; James, 1981; Taylor and Sheppard, 1986; Harmon and Hoefs, 1995; Eiler, 2001; Bindeman, 2008).

Elevated $\delta^{18} \mathrm{O}$ melt values, however, may also arise through closed-system fractional crystallization if the crystallizing mineral assemblage is dominated by minerals depleted in ${ }^{18} \mathrm{O}$ relative to the melt (Taylor, 1968). In general, equilibrium $\delta^{18} \mathrm{O}$ values of igneous minerals decrease in the following order: quartz > alkali-feldspar > calcic plagioclase > biotite > apatite > orthopyroxene > zircon > clinopyroxene $>$ amphibole $>$ garnet $>$ olivine $>$ oxides (see summary in Eiler, 2001; Valley, 2003). Minerals such as olivine, magnetite, garnet, and amphibole may have lower $\delta^{18} \mathrm{O}$ values than basaltic melts at magmatic temperatures and crystallizing mineral assemblages dominated by these minerals will increase the ${ }^{18} \mathrm{O} /{ }^{16} \mathrm{O}$ ratio of the residual melt. Conversely, crystallization and fractionation of quartz or albitic plagioclase or K-feldspar from a melt can result in ${ }^{18} \mathrm{O}$ depletion.

The variations in melt oxygen isotope composition produced during fractional crystallization has long been the subject of study (e.g., Taylor \& Epstein, 1962; Garlick 1966; Taylor, 1968; Taylor and Sheppard, 1986). Taylor \& Epstein (1962) first approached this problem through modeling in a simple binary system using the Rayleigh fractionation equation:

$$
\frac{R}{R_{0}}=f^{\alpha-1}
$$

Where $f$ is the fraction of melt remaining at any stage, $\alpha$ is the fractionation factor between crystals and melt (assumed to be constant), $R_{0}$ is the isotopic ratio $\left({ }^{18} \mathrm{O} /{ }^{16} \mathrm{O}\right)$ in the original melt, and $\mathrm{R}$ is the isotopic ratio of melt at any stage of crystallization. This equation can be written in terms of $\delta$ and $\Delta$ values as:

\footnotetext{
${ }^{1} \delta^{18} \mathrm{O}$ values reported in this paper are always relative to Standard Mean Ocean Water (SMOW). $\Delta{ }^{18} \mathrm{O}_{\mathrm{A}-\mathrm{B}}$ is the isotopic fractionation between phase $\mathrm{A}$ and $\mathrm{B}$ and is equal to $\delta^{18} \mathrm{O}_{\mathrm{A}}-\delta^{18} \mathrm{O}_{\mathrm{B}}$. We use subscripts after $\delta^{18} \mathrm{O}, \Delta^{18} \mathrm{O}$, and $\mathrm{Mg \#}$ to indicate a mineral, melt, or whole rock sample. The following abbreviations are used: plagioclase (plag), clinopyroxene (cpx), orthopyroxene (opx), pyroxene (pyx), olivine (ol), fayalite (fay), zircon (zrc), qtz (quartz), whole rock (WR), mineral (min).
} 


$$
\frac{1000+\delta}{1000+\delta_{0}} \cong f^{\left(\frac{\Delta}{1000}\right)}
$$

where $\Delta=\delta_{\text {crystals }}-\delta_{\text {melt }}, \delta=$ melt $\delta^{18} \mathrm{O}$, and $\delta_{0}=$ initial melt $\delta^{18} \mathrm{O}$. Taylor \& Epstein (1962) recognized that the crystallization of natural magmas would be enormously more complicated than models in binary systems, and that the detailed variations would depend on the specific system studied. Taylor (1968) summarized this complexity succinctly:

"The types of minerals crystallizing, their sequence of crystallization, their temperatures of formation, the degree to which they are effectively removed from interaction with the melt by armoring and/or settling, and so forth, all will affect the oxygen isotope changes that occur in the melt phase. The above factors vary with magma composition, $P_{\mathrm{H}_{2} \mathrm{O}}$, oxygen fugacity, silicate melt viscosity, etc., so the exact nature of the oxygen isotope changes that should occur during magmatic differentiation would be very difficult to predict even if we had full knowledge of the equilibrium fractionation factors for oxygen isotope exchange for all the important igneous minerals at magmatic temperatures."

At that time, however, Taylor (1968) made some first order predictions. For example, he suggested that higher temperature systems should experience smaller increases in $\delta^{18} \mathrm{O}$ due to the smaller mineral-melt fractionations at elevated temperatures, early crystallization of oxides with relatively low ${ }^{18} \mathrm{O} /{ }^{16} \mathrm{O}$ values would increase the ${ }^{18} \mathrm{O} /{ }^{16} \mathrm{O}$ values of the melt, and that as the $\mathrm{SiO}_{2}$ content of a melt increases, so should its $\delta^{18} \mathrm{O}$ value.

Since this time, numerous researchers have attempted to investigate this problem in more detail, primarily though studying igneous sequences where fractional crystallization likely played an important role in generating the observed lithologic variations. The oxygen isotope ratios of layered mafic intrusions classically received attention as they could potentially provide examples of closed-system differentiation of a single magma body. Although hydrothermal exchange obscured magmatic $\delta^{18} \mathrm{O}$ whole rock and mineral values for the Skaergaard Intrusion (Taylor and Epstein, 1963; Taylor and Forester, 1979) and the Muskox Intrusion (Taylor, 1968), the Kiglapait Intrusion demonstrated close-system behavior with respect to oxygen isotopes (Kalamarides, 1984). Whole rock and mineral $\delta^{18} \mathrm{O}$ data in the Kiglapait intrusion suggest negligible changes in $\delta^{18} \mathrm{O}$ of a crystallizing anhydrous olivine tholeiite, resulting from the cancelling effects of simultaneous crystallization of low $\delta^{18} \mathrm{O}$ mafic phases and high $\delta^{18} \mathrm{O}$ feldspar (Fig. 1). However, for the Kiglapait intrusion most of the constraints on magmatic $\delta^{18} \mathrm{O}$ values are from cumulates corresponding to $>>90 \%$ of the magma crystallized. Thus, the poor constraints on the melt trajectory during earlier stages of crystallization make it difficult to constrain total increases in $\delta^{18} \mathrm{O}$ melt values over the entire crystallization history.

The oxygen isotope variations in suites of volcanic rocks were also investigated in order to quantify the effects of fractional crystallization on melt oxygen isotope compositions. Studied systems 
include tholeiitic basalts, (e.g., the Kiluaea Iki Lava Lake (Anderson et al., 1971) and the Galapagos Spreading Center (Muehlenbachs and Byerly, 1982)), ocean island alkali basalts (e.g., Ascension Island (Sheppard and Harris, 1985) and Tristan de Cunha and Gough Island (Harris et al., 2000)), continental flood basalts (e.g., Yemen (Baker et al., 2000)), hydrous basalts (e.g., the Lesser Antilles (Tollan et al., 2012) and northern Marianas lavas (Woodhead et al., 1987)), and volcanic rocks from Honshu and Hokkaido, Japan (Matsuhisa et al., 1973; Matsuhisa, 1979). These studies found positive, but $\leq 1 \%$ increases in $\delta^{18} \mathrm{O}$ at $80 \%$ fractionation (Fig. 1). For the Galapagos Spreading Center, slightly more pronounced increases up to $\sim 1.2 \%$ at $90 \%$ crystallization were observed, due to titanomagnetite crystallization and marked silica enrichment in the melt at late stages of differentiation of a Fe-Ti basalt (Muehlenbachs and Byerly, 1982). Similar late stage increases in melt $\delta^{18} \mathrm{O}$ is noted in Lau Basin glasses and ascribed to crystallization of oxides (Macpherson and Mattey, 1998).

To compare the natural data to models, many of the mentioned studies implement simple Rayleigh fractionation models (as in equation $1 \& 2$ ) (see Table A.1 for a summary). A major assumption made in this modeling is that equilibrium fractionation factors among crystals and liquid are constant during crystallization. Consequently, the modeled melt trajectory depends strongly on the $\alpha$ value chosen. For example, using an $\alpha$ value of 0.9998 will result in $<0.5 \%$ increase at $90 \%$ crystallization, while an $\alpha$ value of 0.9993 will result in an increase of $\sim 2.3 \%$ at the same degree of fractionation. Both of these $\alpha$ values have been used to model natural systems (e.g., Matsuhisa et al., 1973; Woodhead et al., 1987). Thus, studies implementing Rayleigh fractionation modeling give a first order estimate of expected increases, but do not account for the continual variation in temperature, melt composition, and crystallizing mineralogy throughout the course of crystallization. Exceptions to this include studies that consider slightly more complicated, two to three stage Rayleigh fractionation models (Sheppard and Harris, 1985, Baker et al., 2000).

The recognition that melts could be treated as a mixture of their normative mineralogy (Matthews et al., 1994; Palin et al., 1996; Eiler, 2001) facilitated more complex fractionation models. This appreciation resulted from direct measurement of mineral-melt fractionation factors through careful experimental studies (Stolper and Epstein, 1991; Matthews et al., 1994; Palin et al., 1996; Appora et al., 2003). Treating melts as mixtures of CIPW normative minerals allowed for a more detailed assessment of bulk mineral-melt fractionations arising from varying temperatures, melt composition, and crystallizing minerals over the course of crystallization, thus approximating more realistic conditions in natural systems. Employing this method, Eiler (2001) calculated an increase of 0.6\%o over a $\mathrm{SiO}_{2}$ range of 52-67 wt.\% for equilibrium crystallization experiments on tholeiitic basalts from the Galapagos and the Kane Fracture Zone (Juster et al., 1989) (Fig. 1). Notably, significant elevations in $\delta^{18} \mathrm{O}_{\text {melt }}$ occurred when the equilibrium melt $\mathrm{SiO}_{2}$ content began to appreciably increase, resulting in preferential partitioning of ${ }^{18} \mathrm{O}$ into the melt rather than plagioclase. Using a similar modeling strategy, Cooper et al., (2004) modeled small increases $\left(0.13-0.22 \%\right.$ ) in $\delta^{18} \mathrm{O}$ for crystallizing mid-ocean ridge basalts crystallizing over a limited 
range of $\mathrm{SiO}_{2}$ between 48.5-54.3 wt.\% (Fig. 1). Perhaps the most comprehensive attempt using the CIPW normative approach was developed by Bindeman et al., 2004, using a small increment forward model based on the results of MELTS modeling which provided temperature, crystallizing mineralogies, and melt compositions for different parental melt compositions, including high-Mg basalts, tholeiitic basalts, shoshonites, and high-Al basalts with up to $1 \mathrm{wt} . \% \mathrm{H}_{2} \mathrm{O}$. Their modeling results indicated a $<0.4 \%$ increase in $\delta^{18} \mathrm{O}$ over a melt $\mathrm{SiO}_{2}$ content of 50-75 wt.\% (Fig. 1).

Although these past studies provide a solid framework for assessing the effect of fractional crystallization on melt $\delta^{18} \mathrm{O}$ values, we see several areas where our understanding could be improved.

1) Studies of natural samples have mostly focused on the recent volcanic record. There are several issues that arise during these studies. First, some of the older studies analyzed oxygen isotope values of whole rock powders (e.g., Matsuhisa, 1973; Muehlenbachs and Byerly, 1982), which have been shown to be generally susceptible to secondary alteration. Second, although more recent studies have analyzed phenocrysts from recently erupted volcanic rocks, generally avoiding issues associated with secondary alteration, it may be difficult to conclusively demonstrate consanguinity among different samples in a volcanic suite and thus the relationship between their oxygen isotope compositions. Further, lavas may carry a heterogeneous load of both phenocrysts and antecrysts from deeper in the volcanic plumbing system.

2) Existing studies have generally examined fractional crystallization trends before significant silica-enrichment has occurred ( $\left.\mathrm{F}>\sim 0.2, \mathrm{SiO}_{2}<70 \mathrm{wt} . \%\right)$ and therefore may not be recording the full increases in melt $\delta^{18} \mathrm{O}$ values possible. In the few studies that examined volcanic rocks at elevated $\mathrm{SiO}_{2}$ contents (>70 wt.\%), oxygen isotope analyses were done on whole rock powders, which are less likely to preserve magmatic $\delta^{18} \mathrm{O}$ values than mineral phenocrysts (e.g., Matsuhisa, 1979; Muehlenbachs and Byerly, 1982).

3) Modeling studies that have explored melt trajectories at higher $\mathrm{SiO}_{2}$ values are not in agreement with one another or results from natural studies. For example, Eiler (2001) found an increase of $\sim 0.6 \%$ from $50-67 \mathrm{wt} . \% \mathrm{SiO}_{2}$ for a crystallizing tholeiitic basalt. In contrast, Bindeman et al., (2004) modeled $\delta^{18} \mathrm{O}$ trajectories based on MELTS model results for an array of initial starting compositions, including hydrous arc basalts, and defined a "normal- $\delta^{18} \mathrm{O}$ differentiation array" with increases of $\leq 0.4 \%$ at $90 \%$ fractionation $\left(75 \mathrm{wt} . \% \mathrm{SiO}_{2}\right.$ ). These authors suggested that any magma with $\delta^{18} \mathrm{O}$ values above this differentiation array are unlikely to be produced by closed-system fractional crystallization under the melt compositions and crystallization conditions they examined (Fig. 1). Studies of natural systems of similar melt compositions demonstrate significantly larger increases of up to $\sim 1 \%$, in agreement with the maximum limits originally suggested by Taylor and Sheppard (1986). Yet other studies cite that 1-2\%o increases may be expected (Valley et al., 2002). The disparity in these estimates suggest that the variations expected through closed system differentiation are a) not fully understood and/or b) may vary depending on the compositions of melt crystallizing and the conditions of crystallization. 
As melts from different tectonic settings are characterized by distinct melt compositions and conditions of crystallization, it may be expected that the changes in melt $\delta^{18} \mathrm{O}$ values during fractional crystallization could be variable in these different locations. For example, anhydrous tholeiitic basalts from mid-ocean ridges and intra-continental volcanism are dominated by olivine, clinopyroxene, and plagioclase crystallization at relatively high magmatic temperatures $\left(1330-900^{\circ} \mathrm{C}\right)$ (Walker et al., 1979; Stolper, 1980; Grove et al., 1992; Villiger et al., 2004; Whitaker et al., 2008). Relatively limited increases in ${ }^{18} \mathrm{O} /{ }^{16} \mathrm{O}$ ratios in a crystallizing tholeiitic melt would be expected due to the high temperatures of crystallization and a crystallizing assemblage rich in plagioclase. In contrast, hydrous basalts typical of subduction zones are characterized by crystallization of anorthite-rich plagioclase, hornblende, pyroxenes, oxides, and garnet at relatively lower temperatures (1200-650 ${ }^{\circ} \mathrm{C}$ ) (Alonso-Perez et al., 2009; Jagoutz, 2010; Melekhova et al., 2015; Müntener et al., 2001; Nandedkar et al., 2014; Sisson and Grove, 1993; Sisson et al., 2005). Fractional crystallization of such low $\delta^{18} \mathrm{O}$ mineral assemblages at low magmatic temperatures would be expected to produce more pronounced increases in melt $\delta^{18} \mathrm{O}$ values of crystallizing hydrous subduction zone magmas. Consequently, liquid lines of descent (LLDs) defined by contrasting melt compositions and physical conditions of crystallization may have distinctly different $\delta^{18} \mathrm{O}_{\text {melt }}$ trajectories.

Although Bindeman et al. (2004) explored the variations in trajectories expected for melts with different compositions and crystallization conditions his models were based on MELTS modeling results, which does a poor job predicting crystallizing mineralogy and melt compositions for hydrous melts at intermediate compositions. In particular, the solid solution model for hornblende, a critical crystallizing phase in many hydrous magmas, as well as biotite are in need of recalibration. In addition, the maximum increases of $\sim 0.4 \%$ over a crystallization interval of 50-70 wt.\% $\mathrm{SiO}_{2}$ predicted by Bindeman et al., 2004 strongly contrasts to the trends predicted by natural studies of $>1 \%$. To place better constraints on this problem, we modeled in detail the oxygen isotope trajectories of six liquid lines of descent (LLDs) mostly characterized by near primitive parental melt compositions, crystallization over a wide array of melt compositions (from basalt to high-silica melt), and distinct crystallizing phase assemblages, temperatures, and melt compositions (Table 1). Three of these LLDs are experimentally constrained (Nandedkhar et al., 2014; Villiger et al., 2004; Whitaker et al., 2008) and were selected as they covered nearly the full crystallization interval for their chosen starting compositions ( $F$ ranging from 1 to 0.02 ) and provide detailed constraints on melt compositions, temperatures, and crystallizing minerals. The experimental LLDs range from anhydrous, tholeiitic melts characterized by two pyroxene and plagioclase crystallizing assemblages (Villiger et al., 2004; Whitaker et al., 2008) to hydrous, calc-alkaline melts which crystallized copious amounts of Fe-Ti oxides and amphibole (Nandedkhar et al., 2014). The three other studied LLDs are derived from field studies of plutonic sequences comprised of rocks representing cumulate and solidified melts. These include the Kohistan paleo-arc (a hydrous calc-alkaline LLD, Jagoutz 2010), the Upper and Upper Main Zones (UUMZ) of the Bushveld Complex, South Africa (a 
low- $\mathrm{H}_{2} \mathrm{O}$, tholeiitic basalt; Vantongeren et al., 2011), and the Dariv Igneous Complex, Mongolia (a hydrous, high-K basalt; Bucholz et al., 2014a,b). Based on major and trace element geochemistry of whole rocks and minerals, as well as quantitative modeling, these suites appear to have formed predominantly through fractional crystallization resulting in the production of high $\mathrm{SiO}_{2}$ derivative melts (Jagoutz, 2010; Vantongeren et al., 2011; Bucholz et al., 2014a,b). Variations in crystallizing minerals, temperature estimates, and the equilibrium melt compositions for these localities have been studied in detail making them ideal candidates for this study. In order to compare our model results to natural data we measured the oxygen isotope composition of mineral separates from the Bushveld and Dariv Igneous Complexes. In doing this, our aim is to asses to what extent the oxygen isotope trajectories of these two sequences can be explained through closed-system processes alone. In our examination of these two suites, we also explore the effects of subsolidus re-equilibration, potential assimilation (through $\mathrm{Sr}$ and $\mathrm{Nd}$ isotope analyses of clinopyroxenes), and $\delta^{18} \mathrm{O}$ values of the parental melts in order to evaluate all possible contributions from open system behavior to the oxygen isotope composition of the crystallizing melts. Our comprehensive application of closed-system modeling to natural and experimentally determined LLDs allows us to explore the potential variations in $\delta^{18} \mathrm{O}$ expected among different magma compositions and crystallization conditions. Our modeling results also permit us to assess the range of $\delta^{18} \mathrm{O}$ values permissible through closed system fractional crystallization of mantle-derived basalts, as well as, the variations in $\Delta^{18} \mathrm{O}_{\text {zircon-melt }}$ for different silicic melt compositions and temperatures, which are critically important when using zircon $\delta^{18} \mathrm{O}$ to reconstruct magmatic $\delta^{18} \mathrm{O}$ values.

\section{STUDIED LIQUID LINES OF DESCENT (LLD)}

Details of the studied LLD are summarized in Table 1. A more detailed discussion is given to the Bushveld Complex and Dariv Igneous Complex as mineral separates were analyzed from these two sequences.

\subsection{Experimental LLD}

\subsubsection{Villiger et al., 2004 - Anhydrous tholeiitic, $1.0 \mathrm{GPa}$}

Villiger et al., 2004 characterized the LLD of a fractionally crystallizing synthetic anhydrous tholeiitic basalt at $1.0 \mathrm{GPa}$ over a temperature range of $1330-1060^{\circ} \mathrm{C}$ at relatively low oxygen fugacities (C-CO- $\mathrm{CO}_{2}$ equilibrium). At high melt fractions (>0.7) the crystallizing phase assemblage is characterized by a dominance of clinopyroxene and orthopyroxene with lesser olivine and spinel. Plagioclase $\left(\mathrm{X}_{\mathrm{An}}=0.64\right)$ begins crystallizing at $1210^{\circ} \mathrm{C}$ and quartz appears at the very end stages of crystallization $\left(\mathrm{F}=0.06, \mathrm{~T}=1060^{\circ} \mathrm{C}\right)$.

\subsubsection{Whitaker et al., $2008-0.4 w t . \% \mathrm{H}_{2} \mathrm{O}$ oliving thoeliite, $0.4 \mathrm{GPa}$}

Whitaker et al., 2008 determined the LLD of a fractionally crystallizing natural olivine tholeiite from the Snake River Plain with an initial water content of 0.4 wt. $\% \mathrm{H}_{2} \mathrm{O}$ over a temperature range of 
$1280-940^{\circ} \mathrm{C}$ at $0.4 \mathrm{GPa}$ and buffered at graphite- $\mathrm{CO}$ equilibrium. Initial fractionation (from $\mathrm{F}=1-0.58$, $\left.1280-1160^{\circ} \mathrm{C}\right)$ is defined by olivine and plagioclase crystallization $\left(\mathrm{X}_{\mathrm{An}}=0.70\right)$. At this point, clinopyroxene percentage of the crystallizing phase assemblage increases. At $\mathrm{F}<0.1$, apatite, ilmenite, and pigeonite begin crystallizing in small amounts. Notably, olivine is crystallizing phase across the entire LLD, albeit in low modal abundances at low melt fractions.

\subsubsection{Nandedkhar et al., 2014 - hydrous tholeiite, 0.7 GPa}

Nandedkhar et al., 2014 experimentally crystallize a synthetic, hydrous (3.6 wt.\% $\mathrm{H}_{2} \mathrm{O}$ initial) olivine tholeiite at $0.7 \mathrm{GPa}$ over a temperature range of $1170-700^{\circ} \mathrm{C}$ near the nickel-nickel oxide buffer. High temperature and melt fraction $\left(\mathrm{T}>1040^{\circ} \mathrm{C}, \mathrm{F}>0.6\right)$ crystallization is dominated by clinopyroxene with smaller amounts of olivine and magnetite. Subsequent crystallization is characterized by amphibole, clinopyroxene, plagioclase, and magnetite saturation. At the end stages of crystallization $(\mathrm{F}<0.2$, $\mathrm{T}<730^{\circ} \mathrm{C}$ ), quartz and biotite join the crystallizing assemblage.

\subsection{Natural LLD: Geologic Setting, Petrology, and Previous Oxygen Isotope Studies}

\subsubsection{Kohistan Paleo-Arc, Pakistan - hydrous calc-alkaline basalt}

The Kohistan paleo-arc is a complete, preserved island arc section, with harzburgitic mantle at the base ( $\sim 50 \mathrm{~km}$ paleo depths), a thick ( $20 \mathrm{~km})$ section of ultramafic to mafic cumulates in the lower crust, an upper crust characterized by $\sim 25 \mathrm{~km}$ of evolved granitoids, and a thin $(\sim 5 \mathrm{~km})$ volcano-sedimentary cover (Burg, 2011). The formation of the evolved igneous upper crust through fractional crystallization of a primitive, hydrous arc basalt has been quantitatively modeled using average cumulate compositions characteristic of the middle to lower crust (Jagoutz 2010). Crystallizing lithologies include dunite, wehrlite, websterite, hornblendite, garnet- and hornblende-bearing gabbro, diorite, and minor tonalite. Mineral modal abundances of these cumulate lithologies are given in (Jagoutz and Schmidt, 2013). Temperatures of crystallization likely varied between $1100-1200^{\circ} \mathrm{C}$ from the parental melt liquidus to $<700^{\circ} \mathrm{C}$ for near solidus granitic melts in the upper crust and fractionation occurred dominantly in the mid- to lower crust (0.8 to $1.5 \mathrm{GPa}$ ) (Jagoutz 2014).

\subsubsection{Bushveld Complex, South Africa - 1 wt. $\% \mathrm{H}_{2} \mathrm{O}$ basalt, $0.2 \mathrm{GPa}$}

The Rustenberg Layered Suite (RLS) of the Bushveld Complex, South Africa constitutes a complete, approximately $8 \mathrm{~km}$ thick stratigraphic section of progressively more evolved cumulate lithologies, from harzburgite near the base to fayalite and apatite-bearing diorite at the top (Gruenewaldt, 1973; Molyneux, 1974; Cameron, 1978; Cameron, 1980). The RLS was emplaced in four main pulses of magma, roughly corresponding to the start of the Lower Zone, Critical Zone, Main Zone, and Upper Zone. The last major pulse of magma into the RLS occurred just below the level of the Pyroxenite Marker (Cawthorn et al., 1991; VanTongeren and Mathez, 2013). At this level a major reversal in major and trace element composition occurs coincidently with a break in ${ }^{87} \mathrm{Sr} /{ }^{86} \mathrm{Sr}$ values (Sharpe, 1985; Kruger et al., 
1987) (Fig. 2b). Above the Pyroxenite Marker, the observed cumulate phase assemblage indicates a crystallization sequence of pyroxene $(\mathrm{pyx})+$ plagioclase $(\mathrm{plg}) \rightarrow \mathrm{pyx}+\mathrm{plg}+$ magnetite $(\mathrm{mgt}) \rightarrow \mathrm{pyx}+$ $\mathrm{plg}+\mathrm{mgt}+$ fayalite (fay) $\rightarrow$ pyx + plg $+\mathrm{mt}+$ fay + apatite. Fe-Mg silicate minerals become less magnesian and plagioclase more albite-rich towards the roof of the Upper Zone with no major reversals (Molyneux, 1974; Tegner et al., 2006; VanTongeren et al., 2010), suggesting no volumetrically significant additional input of magma or assimilation during crystallization. On the basis of this geochemical distinction, VanTongeren et al. (2010) interpreted the stratigraphic interval above the Pyroxenite Marker as a single tholeiitic fractionation sequence and termed it the combined Upper and Upper Main Zone (UUMZ). The initial parental melt likely had $1 \mathrm{wt} \% \mathrm{H}_{2} \mathrm{O}$ and crystallized over a temperature range of $1200-940^{\circ} \mathrm{C}$ at $0.2 \mathrm{GPa}$ near the quartz-fayalite-magnetite buffer (VanTongeren et al. 2010). The volcanic rocks of the Rooiberg Group, the intrusive Rashoop Granophyre Suite (e.g. Stavoren Granophyre), and the Lebowa and Nebo Granites overlie the RLS. VanTongeren et al. (2010) and Mathez et al. (2013) suggested that some portions of the felsic volcanic rocks of the Rooiberg Group and/or the Rashoop Granophyre are cogenetic with the RLS and represent the residual liquids from the prolonged fractionation of the UUMZ parental magma. In particular, Mathez et al. (2013) suggest that the highly ferroan, metaluminous Stavoren Granophyre is the best candidate for the escaped residual liquid after fractional crystallization of the UUMZ cumulate lithologies. Evidence supporting this hypothesis includes 1) their $\varepsilon_{\mathrm{Nd}}$ values (Twist and Harmer, 1987; Buchanan et al., 2004), oxygen isotope compositions (Fourie and Harris, 2011), and ages (e.g. Scoates et al., 2012) are similar to those of the RLS; and 2) quantitative geochemical modeling and mass balance calculations demonstrate that they are an appropriate melt counterpart to cumulates of the UUMZ (VanTongeren et al., 2010; VanTongeren and Mathez, 2012).

Several previous studies have investigated the oxygen isotope composition of mineral separates from the RLS. Plagioclase and pyroxene $\delta^{18} \mathrm{O}$ values vary between $6.0-8.3 \%$ and $5.8-6.7 \%$, respectively (Schiffries and Rye, 1989; Harris and Chaumba, 2001; Harris et al., 2005). These mineral values correspond to $\delta^{18} \mathrm{O}$ values of $6.8 \%$ and $7.3 \%$ for the parental melts in the Main/Critical and Upper Zones, respectively, suggesting that the parental magmas of the Bushveld Complex were enriched in ${ }^{18} \mathrm{O}$ compared to typical mantle-derived melts and required at least $10 \%$ of its oxygen to be derived from elevated ${ }^{18} \mathrm{O} /{ }^{16} \mathrm{O}$ crustal material (assuming an assimilant $\delta^{18} \mathrm{O}$ value of $15 \%$ ) (Schiffries and Rye, 1989). Analysis of quartz and zircon $\delta^{18} \mathrm{O}$ values from the overlying granites and granophyres of the Bushveld Complex yield estimates of 6.6-6.9\% for the original silicic magmas (Fourie and Harris, 2011), similar to the range of the mafic cumulates. Although multiple studies have demonstrated that the $\delta^{18} \mathrm{O}$ values of the RLS parent magmas are $\sim 1-1.5 \%$ higher than that of the typical value of mantle-derived melts $(\sim 5.7 \%$ o) (Schiffries and Rye, 1989; Reid et al., 1993; Harris and Chaumba, 2001), they conclude that the elevated $\delta^{18} \mathrm{O}$ values of the parent magmas were acquired prior to emplacement within the RLS magma chamber and is not due to progressive crustal assimilation within the RLS itself. 


\subsubsection{Dariv Igneous Complex, Mongolia - High-K, hydrous basalt, 0.3-0.5 GPa}

The Dariv Range of western Mongolia exposes the contact between the Proterozoic high-grade metamorphic rocks of the Altai Allochthon and the Lake Terrane, an Ediacaran to Early Paleozoic island arc system comprised of ophiolites and arc-related plutonic and volcano-sedimentary rocks (Badarch and Cunningham, 2002; Khain, 2003; Dijkstra et al., 2006). The km-scale, middle Cambrian Dariv Igneous Complex belongs to the latter and is comprised of a suite of high-K plutonic rocks, including phlogopitebearing cumulative wehrlites and clinopyroxenites, mafic monzogabbro and monzodiorites, and (quartz)monzonites that are cross-cut by late-stage high- $\mathrm{SiO}_{2}$ and lamprophyre dikes (see Bucholz et al., 2014a,b for detailed field and petrographic descriptions). The observed lithological variability, petrographic observations, mineral and whole rock geochemistry suggest that the plutonic rocks can be ascribed to a common fractionation sequence defined by a progression of crystallizing major mineralogy in the order of olivine + clinopyroxene $(\mathrm{cpx})+$ phlogopite $(\mathrm{phl}) \rightarrow \mathrm{cpx}+\mathrm{phl}+$ apatite $\rightarrow \mathrm{cpx}+$ biotite $(\mathrm{bt})+\mathrm{K}$-feldspar $(\mathrm{kfsp})+$ plagioclase $(\mathrm{plg}) \rightarrow \mathrm{cpx}+\mathrm{bt}+\mathrm{kfsp}+\mathrm{plg}+$ amphibole + quartz. Several primitive high-K basaltic dikes have compositions appropriate to be parental to the observed cumulate lithologies and the LLD of their average composition has been quantitatively modeled (Bucholz et al. 2014a). The parental melts to this sequence likely had $\sim 2.5 \mathrm{wt} . \% \mathrm{H}_{2} \mathrm{O}$ and crystallized over a temperature range of $1150-700^{\circ} \mathrm{C}$ and 0.3-0.5 GPa (Bucholz et al., 2014a). Although feldspar-bearing plutonic lithologies can range from cumulative to liquid-like in character, most quartz-monzonites and all of the aplite dikes have major and trace element compositions appropriate for liquid-dominated plutonics representative of late-stage differentiated melts in the fractionation sequence. Although, the lithologic and chemical variability can be explained through a simple closed-system fractional crystallization model, Bucholz et al., 2014b could not eliminate the possibility of assimilation. No previous oxygen isotope data has been reported for Dariv Igneous Complex.

\section{CLOSED SYSTEM FRACTIONAL CRYSTALLIZATION MODELING}

The aim of the closed system modeling is twofold. First, closed system modeling of various experimental and natural sequences with an array of starting major element compositions, water contents, crystallizing phases, and pressure-temperature conditions allows us to constrain the permissible range of changes in melt $\delta^{18} \mathrm{O}$ values during fractional crystallization. Second, the modeling provides a theoretical basis to compare with the mineral data obtained for the UUMZ of the Bushveld Complex and the Dariv Igneous Complex (see Sections $4 \& 5$ ), which allows us to better quantify the relative roles of assimilation and magmatic differentiation in producing mineral or melt $\delta^{18} \mathrm{O}$ values. A derivation and description of the model, as well as a complete example model in an Excel spreadsheet are provided in the Appendix, however we discuss the main features of the model here.

\subsection{Model Setup}


We used melt compositions from six experimentally and naturally constrained LLDs (see Section 2 and Table 1), which start with a parental basalt and evolve towards granitic compositions at low melt fractions. Modal percentages of crystallizing minerals were constrained from modal abundances from studied samples across the sequences, MELTS thermodynamic modeling (for the relatively dry parental melt of Bushveld Complex), or the experimental datasets and then converted to mass percentages for modeling purposes. Melt temperatures across the LLDs are either from the values reported for the experimental LLDs or estimated using mineral geothermometers (Sun et al., 2013; Liang et al., 2013; Bucholz et al., 2014a), and verified against temperature paths of experimentally determined LLDs with similar parental melts (i.e., Whitaker et al., 2008 and Righter \& Carmichael, 1996) for the natural LLDs. From an initially defined parental melt $\delta^{18} \mathrm{O}$ value, we subtract bulk cumulate $\delta^{18} \mathrm{O}$ values in a stepwise fashion from the crystallizing melt. (See Appendix for discussion of use of $\delta^{18} \mathrm{O}$ versus ${ }^{18} \mathrm{O} /{ }^{16} \mathrm{O}$ in model calculations.) It is important to note that the relative magnitude of the $\delta^{18} \mathrm{O}$ trajectory of the crystallizing melt is independent of the chosen initial melt value. Bulk cumulate-melt fractionations are calculated knowing the modal percentage (converted to mass percent) of the crystallized minerals at each fractionation step and calculated mineral-melt fractionation factors. Using estimated melt temperatures, treating the melt as a mixture of CIPW normative minerals, and using experimentally determined $\Delta^{18} \mathrm{O}_{\min }$ min, we calculated the temperature and melt composition-dependent mineral-melt fractionations $\left(\Delta_{n}^{i+1}(T)\right)$ at each fractionation step $i+1$ and for each crystallization mineral $n$. Bulk cumulate-melt per mil fractionations can then be calculated as:

$$
\Delta^{i+1}=\delta^{18} O_{\text {cumulate }}^{i+1}-\delta^{18} O_{\text {melt }}^{i+1}=\sum\left(M_{n}^{i+1} \times \Delta_{n}^{i+1}(T)\right)
$$

where $M_{n}^{i+1}$ is the fraction of total cumulate oxygen contained in crystallizing mineral $n$ at fractionation step $i+1$. The anorthite composition of plagioclase and its effect on $\Delta_{\text {plag-melt }}(T)$ was explicitly considered in the model. Using mass balance constraints and making the simplification that the melt and bulk cumulate compositions have approximately equal mass percentages of oxygen (in general, 40-50 wt.\% O):

$$
\delta^{18} O_{\text {melt }}^{i}=\left(\delta^{18} O_{\text {melt }}^{i+1}\right)\left(X^{i+1}\right)+\left(\delta^{18} O_{\text {cumulate }}^{i+1}\right)\left(1-X^{i+1}\right)
$$

where $X^{i+1}$ is the fraction of melt remaining at step $i+1$ and accounts for decreasing melt mass during fractionation and is defined as $X^{i+1}=F^{i+1} / F^{i}$. Combining Eqs. (3) and (4), $\delta^{18} \mathrm{O}_{\text {melt }}$ at the next fractionation step $i+1$ can then be calculated as:

$$
\delta^{18} O_{m e l t}^{i+1}=\delta^{18} O_{m e l t}^{i}-\Delta^{i+1}\left(1-X^{i+1}\right)
$$




\subsection{Uncertainties Associated with Model}

There are several sources of uncertainties associated with the model that must be considered before interpreting its results. Melt composition, crystallizing mineralogy, and temperatures for the experimentally determined LLDs are better constrained than for the natural LLDs. For natural LLDs these parameters must be determined through indirect methods. The composition of the natural crystallizing melts has been previously constrained either through mass balance modeling for Kohistan Arc and the Dariv Igneous Complex (Jagoutz, 2010; Bucholz et al, 2014b) or MELTS thermodynamic modeling for the UUMZ of the Bushveld Complex (VanTongeren et al., 2010), both of which have inherent uncertainties. Uncertainties associated with mass balance modeling have been previously discussed (Jagoutz, 2010) and primarily arise from assuming an average composition for each cumulate lithology and an initial parental melt composition. A second uncertainty with the natural modeled LLDs are the magmatic temperatures used. We attempted to limit such uncertainties through implementing temperature constraints from mineral thermometers (e.g., from Bucholz et al., 2014a and Sun et al., 2013) and comparison to temperature paths of experimentally determined LLDs with similar parental melts. MELTS thermodynamic modeling is dependent on the accuracy and consistency of the mineral thermodynamic properties data set used. For relatively anhydrous systems (such as the UUMZ), where amphibole and biotite are not major crystallizing phases, MELTS generally reproduces experimentally observed melt compositions and crystallization sequences.

Due to poor constraints on oxygen isotope fractionations involving silicate melts and minerals, our model approximates the melt as a mixture of CIPW normative minerals, as proposed by Eiler et al., (2001). A general similarity between isotope fractionations for experimental melt compositions and chemically similar minerals suggest that this is the best available approach to estimate mineral-melt fractionations for melt compositions that have not been examined experimentally (Matthews et al., 1994; Palin et al., 1996; Eiler, 2001; Appora et al., 2003). However, the CIPW normative calculations do not consider the water content of the melt. As no study of isotopic fractionations involving significantly hydrous silicate melts exist, it is unclear how dissolved water would affect mineral-melt fractionations. Minerals and melts with high ratios of network-forming cations (e.g., Si and Al) to network-modifying cations (e.g., $\mathrm{Na}, \mathrm{Ca}$, and $\mathrm{Mg}$ ) preferentially favor ${ }^{18} \mathrm{O}$ (Appora et al., 2003). As interaction of dissolved $\mathrm{H}_{2} \mathrm{O}$ with bridging oxygen in the melt framework produces $\mathrm{OH}^{-}$groups and a less polymerized melt (Mysen et al., 1980), it is possible that increased water contents would limit the partitioning of ${ }^{18} \mathrm{O}$ into the melt. Further experimental work on hydrous melts must be done to rigorously quantify the effects of dissolved $\mathrm{H}_{2} \mathrm{O}$ on oxygen isotope fractionations between melts and minerals.

\section{SAMPLE SELECTION AND ANALYTICAL METHODS}

Of the studied LLDs, we selected plutonic samples from the UUMZ of the Bushveld Igneous Complex and the Dariv Igneous Complex to obtain natural mineral oxygen isotope data in order to compare to our 
model. These were selected as they represent the products of fractional crystallization of significantly different parental melt compositions crystallizing under distinct conditions. We first present the analytical methods and a discussion of the natural data. We then discuss the model results and compare them to the natural data.

\subsection{Sample Selection}

Nine samples from the UUMZ of the Eastern Limb of the Bushveld Complex were selected for analysis. These samples include gabbronorites to olivine-magnetite gabbros with whole rock $\mathrm{Mg \#} \mathrm{(molar}$ $\left.\mathrm{Mg} /\left(\mathrm{Mg}+\mathrm{Fe}_{\text {total }}\right) * 100\right)$ varying from 74.7 to 9.2. Whole rock and mineral geochemistry for these samples are reported in VanTongeren et al. (2010). Stratigraphic height (in meters) is relative to the Pyroxenite Marker. Seventeen samples from the Dariv Igneous Complex were chosen from ultramafic phlogopite wehrlites to evolved quartz monzonites and felsic dikes (Table 3). Whole rock Mg\#'s range from 90.7 in the most primitive wehrlite to 32.2 in a felsic dike.

\subsection{Infrared Laser Fluorination Analyses}

Mineral separates and a whole rock powder were analyzed for $\delta^{18} \mathrm{O}$ values by infrared laser fluorination technique (ILFT) using $\mathrm{BrF}_{5}$ with a $\mathrm{CO}_{2}$ laser at Yale University. This method has been previously described by Eiler et al. (1996) and Wang et al. (2011), and is based on methods developed by Sharp (1990) and Valley et al. (1995). Whole rock samples were crushed either by hand using a mortar and pestle or by disc mill to a grain size of $<500 \mu \mathrm{m}$ and sieved to obtain grain sizes between $150-500 \mu \mathrm{m}$. Samples were then ultrasonically cleaned in distilled water, separated using a Franz magnetic separator, and handpicked under a binocular microscope. Crystals with visible inclusions and/or alteration were discarded. For one sample of the host lithology of the Dariv Igneous Complex (MO-11-2, serpentinized harzburgite), a whole rock powder was prepared in an agate mill and pressed into a pellet for analysis. The total number of analyzed minerals and whole rock powders from the Dariv Igneous Complex are as follows: 6 olivine, 10 clinopyroxene, 12 phlogopite/biotite, 2 quartz, and 1 whole rock powder. For the UUMZ of the Bushveld Complex, 3 clinopyroxene, 3 orthopyroxene, 9 plagioclase, 3 fayalitic olivine, and 2 magnetite were analyzed. At least two aliquots of each mineral were analyzed at least to ensure reproducibility. Measurement of both garnet (UWG-2, Gore Mountain Garnet from New York) and olivine (KHX-1, Kilbourne Hole olivine from New Mexico) standards were interspersed between every four unknown measurements. Long term reproducibility of the standards are UWG-2 $=5.84 \pm 0.10 \%$, KHX-1 $=5.27 \pm 0.08 \%$ o $(1 \sigma)$, which compare favorably with the accepted values (UWG-2 $=5.80 \%$, (Valley et al., 1995), KHX-1 = 5.23\%, (Sharp, 1990), (see Table A.2 for full results of these standards). All oxygen isotope measurements of unknowns were corrected by the difference between the measured and accepted values for the standards bracketing their analysis. Average analytical precision of the mass spectrometer measurements was $(\sim 0.01 \%, 1 \sigma)$. For the Dariv Igneous Complex mineral separates, 
average $1 \sigma$ per mil reproducibility is as follows for various minerals: olivine (0.03), clinopyroxene (0.04), and biotite (0.06). For the Bushveld Complex, the range of $1 \sigma$ per mil reproducibility is $0.04-0.20$ for olivine, 0.02-0.12 for clinopyroxene, 0.01-0.07 for orthopyroxene, and 0.01-0.11 for feldspar. The average yields for reported analyses during the course of this work were olivine $97 \%$, clinopyroxene $100 \%$, orthopyroxene $96 \%$, biotite $100 \%$, plagioclase $96 \%$, quartz $92 \%$, and pressed powder pellet $100 \%$. Two reported average analyses had low yields and are not included in the average yields above nor in averages reported in Tables 2 and 3, including olivine from MO-11-8 (yield: 83\%) and plagioclase from B07-041 (yield: 85\%).

\subsection{SIMS Analyses}

Zircons from six samples from the Dariv Igneous Complex were analyzed for in situ oxygen isotope ratios using the CAMECA IMS-1280 ion microprobe at the WiscSIMS Laboratory, University of Wisconsin-Madison. Zircons were separated through mechanical crushing using a disc mill, Frantz magnetic separation, and heavy liquid techniques. Hand-picked zircons were then mounted with zircon standard KIM-5 $\left(\delta^{18} \mathrm{O}_{\text {VSMOW }}=5.09 \%\right.$; Valley, 2003) in in the center of a 1" epoxy mount and polished to expose centers of zircons. All grains were imaged by transmitted and reflected light on a petrographic microscope, and cathodoluminescence (CL) on the JEOL-JXA-733 electron microprobe at MIT to identify internal structures, exposed inclusions, and physical defects prior to selecting locations for SIMS analyses. The mount was sonicated in distilled water and ethanol prior to gold coating. Analytical procedures are described briefly below and in more detail elsewhere (e.g., Kita et al., 2009; Valley and Kita, 2009).

${ }^{16} \mathrm{O},{ }^{18} \mathrm{O}$, and ${ }^{16} \mathrm{O}{ }^{1} \mathrm{H}$ were analyzed simultaneously on different Faraday cups. $\mathrm{A}^{133} \mathrm{Cs}^{+}$primary ion beam (20 keV total impact voltage, $1.84-2.07 \mathrm{nA}$ ) was focused to an oval area of $\sim 10 \mu \mathrm{m}^{2}$. A single measurement consisted of $10 \mathrm{~s}$ of pre-sputtering, $120 \mathrm{~s}$ of automatic tuning of the secondary beam, and 80 $\mathrm{s}$ of analysis, for a total of 3.5 minutes. Every 10-14 sample analyses were bracketed by 8 standard analyses to calibrate for instrumental fractionations and drift. As internal precision for a single spot (commonly $<0.2 \%$ ) is not a good indicator of analytical quality of stable isotope ratios measure by SIMS (Kita et al., 2009; Valley and Kita, 2009), precision of individual $\delta^{18} \mathrm{O}$ analyses is estimated to be the two standard deviations $(2 \sigma)$ of the reproducibility of bracket zircon standards. The average $2 \sigma_{\text {SD }}$ precision for groups of 8 bracketing standard analyses is $0.3 \%$. Full details of both standard and sample analyses are given in Table A.3. Following oxygen isotope analysis, each pit was inspected using an optical microscope at high magnification. Any analyses that intersected cracks or defects in the zircons were considered unreliable due to possible contamination and discarded. All CL images of analyzed grains and locations of spot analyses are given in the Figure A.4.

\subsection{Rb-Sr and Sm-Nd Isotope Analyses of Clinopyroxenes}


Hand-picked clinopyroxene separates for 6 samples from the Dariv Igneous Complex were analyzed for $\mathrm{Rb}, \mathrm{Sr}, \mathrm{Sm}$, and $\mathrm{Nd}$ isotopes. Crushed whole rock samples were carefully handpicked under a binocular microscope to ensure that the separates were $100 \%$ clinopyroxene and free of inclusions and alteration products. Picked crystals were then sonicated in acetone and DI water. For each sample, 20-50 $\mathrm{mg}$ of clinopyroxene was digested in a mixture of $\sim 3 \mathrm{ml}$ of $6 \mathrm{~N} \mathrm{HNO}_{3}$ and $1 \mathrm{ml}$ of HF in a capped Teflon vial at $120-150^{\circ} \mathrm{C}$. After digestion, the sample was dried down and then re-dissolved in $\sim 3 \mathrm{ml}$ of $6 \mathrm{~N}$ $\mathrm{HNO}_{3}$. The process of drying down and re-dissolution was subsequently repeated with solutions of $7.3 \mathrm{~N}$ $\mathrm{HCl}, 2.3 \mathrm{~N} \mathrm{HCl}$, and $1.5 \mathrm{~N} \mathrm{HCl}$. The $1.5 \mathrm{~N} \mathrm{HCl}$ solution was split for concentration and isotopic analysis.

$\mathrm{Sr}$ and $\mathrm{Nd}$ were separated using standard ion exchange techniques. Sr isotopes were measured on an IsotopX Isoprobe T Multi-Collecter thermal ionization mass spectrometer at Rutgers University. Standard NBS987 ${ }^{86} \mathrm{Sr} /{ }^{87} \mathrm{Sr}$ ratio was measured during the run as $0.710245{ }^{86} \mathrm{Sr} /{ }^{87} \mathrm{Sr}(2$ analyses, $2 \sigma= \pm$ 0.000004). Nd isotopes were measured on a Finnigan Neptune Muti-Collector ICP-MS at Rutgers University. Standard JNdi- $1{ }^{143} \mathrm{Nd} /{ }^{144} \mathrm{Nd}$ ratio was measured throughout the run at 0.512042 (4 analyses, $2 \sigma= \pm 0.000016)$. Laboratory procedural blanks are $<200 \mathrm{pg}$.

Dried concentration splits were re-dissolved and diluted in $2 \%$ ultrapure $\mathrm{HNO}_{3}$, and subsequently analyzed by inductively coupled plasma mass spectrometry (ICP-MS) on a Thermo iCapQc ${ }^{\mathrm{TM}}$ mass spectrometer at Rutgers University. Three standards (BCR-2, BIR-1a, BHVO-2) were used to calibrate the instrument with calibration regressions yielding $\mathrm{r}^{2}$ values of $1.000(\mathrm{Rb}), 0.996(\mathrm{Sr}), 0.996(\mathrm{Nd})$ and $0.998(\mathrm{Sm})$. Each sample consisted of 10 main runs, with each run containing 15 sweeps of the desired mass range. An acid blank, drift sample, and standards RGM-2 and GSP-2 (run as unknowns) were analyzed to ensure instrument calibration. Decay constants for Rb of $1.42 \times 10^{-11}$ year $^{-1}$ (Steiger and Jäeger, 1977) and Sm of $6.54 \times 10^{-12}$ year $^{-1}$ (Lugmair and Marti, 1978) were used to calculate initial isotopic compositions. A crystallization age of 502 Ma was used (Bucholz et al., 2017).

\section{ANALYTICAL RESULTS}

Results from ILFT and SIMS oxygen isotope analyses are reported in Tables $2 \& 3$. In addition, whole rock $\mathrm{Mg} \# \& \mathrm{SiO}_{2}$, mineral $\mathrm{Mg} \#$ for constituent ferromagnesian silicate minerals, and anorthite contents of plagioclase are given where available. $\mathrm{Rb}-\mathrm{Sr}$ and $\mathrm{Sm}-\mathrm{Nd}$ isotope analyses of clinopyroxenes from the Dariv Igneous Complex are reported in Table 4.

\section{1. $\delta^{18}$ O Values of the UUMZ of the RLS of the Bushveld Complex}

In the UUMZ, $\delta^{18} \mathrm{O}_{\text {plag }}$ remains fairly constant with increasing stratigraphic height and decreasing $\mathrm{Mg} \#$ with only a slight increase from 6.67-6.77\% in the two stratigraphically lowest samples (122 \& 572 $\left.\mathrm{m}, \mathrm{Mg}_{\mathrm{WR}} 74.7 \& 67.1\right)$ to $6.81-7.26 \%$ in the higher samples (Mg\# $\left.{ }_{\mathrm{WR}} 41.8-9.2\right)$ (Fig. 2a,3a). Pyroxene values also show little variation with increasing stratigraphic height with $\delta^{18} \mathrm{O}_{\mathrm{opx}}$ varying between 6.08$6.18 \%$ and $\delta^{18} \mathrm{O}_{\text {cpx }}$ ranging from 5.76-5.96\%. $\delta^{18} \mathrm{O}_{\text {fay }}$ decreases slightly with increasing stratigraphic 
height from 5.42\%o $\left(\mathrm{Fo}_{46.1}\right)$ at $1312 \mathrm{~m}$ to $5.21 \%$ o $\left(\mathrm{Fo}_{10.3}\right)$ at $2327 \mathrm{~m}$. Magnetite was analyzed from two samples (B07-057 and B07-038) yielding average values of $1.74 \pm 0.37 \%$ and $4.69 \pm 0.33 \%$, respectively. The large uncertainties associated with these averages results from the fact that individual analyses were non-reproducible likely due to fluorination reaction products masking the grains being lazed, which makes it difficult to ensure complete reaction. As such, we do not discuss the magnetite data further.

\section{2. $\delta^{18} O$ Values of the Dariv Igneous Complex}

Across the fractionation sequence there is a general increase in mineral $\delta^{18} \mathrm{O}$ with decreasing whole rock and mineral $\mathrm{Mg \#} \mathrm{(Fig.} \mathrm{3b).} \delta^{18} \mathrm{O}_{\mathrm{ol}}$ in the (phlogopite-)wehrlites increases from 6.51 to $7.53 \%$ o as olivine $\mathrm{Mg \#}$ decreases from 90 to 69 from the most to least primitive samples. Across the same set of ultramafic samples, clinopyroxene increases from 6.64 to $8.16 \%$. Clinopyroxene $\delta^{18} \mathrm{O}$ continues to increase in the mafic cumulates, reaching 9.15\% in monzogabbro sample MO-11-12. Biotite shows no systematic trends across the sequence with values between $6.98-9.44 \%$. The two analyzed quartz separates from (quartz-) monzonites have high $\delta^{18} \mathrm{O}$ values (13.43 and $14.61 \%$ ). The $\delta^{18} \mathrm{O}$ value of a bulk serpentinite sample, which is the host lithology of the Dariv Igneous Complex, is $3.87 \pm 0.04 \%$.

$\delta^{18} \mathrm{O}_{\mathrm{zcn}}$ values were analyzed from a primitive lamprophyre dike $(\mathrm{Mg} \#=67)$, a monzogabbro cumulate (MO-11-12), monzodiorites to (quartz-)monzonites (MO-11-14, MO-11-23, \& MO-11-26), and a felsic dike (MO-11-16). The average $\delta^{18} \mathrm{O}_{\mathrm{zcn}}$ value from the lamprophyre dike is $7.9 \pm 0.1 \%$ o $\left(1 \sigma_{\mathrm{SD}}, \mathrm{n}=\right.$ 14) (Fig. 3b). In the mafic plutonic lithologies, $\delta^{18} \mathrm{O}_{\mathrm{zcn}}$ values are $8.4 \pm 0.1 \%$ o $(n=15)$ in the monzodiorite and $9.4 \pm 0.2 \% 0(n=16)$ in a cumulative monzogabbro. The average $\delta^{18} \mathrm{O}_{\mathrm{zcn}}$ values from the two (quartz)monzonites are indistinguishable at $9.1 \pm 0.1 \%(n=16)$ and $9.1 \pm 0.2 \%(n=17)$. The zircons from the felsic dike cluster in three populations of $\delta^{18} \mathrm{O}_{\mathrm{zcn}}$ values from relatively low values of dark cores $(8.5 \pm$ $0.1 \%, \mathrm{n}=9)$ to higher values of sector zoned zircons $(8.9 \pm 0.1 \%, \mathrm{n}=5)$ and oscillatory zoned rims $(9.3$ $\pm 0.1 \%$, $\mathrm{n}=6$ ). Other than the felsic dike, no other samples demonstrate intra-grain zoning of $\delta^{18} \mathrm{O}_{\mathrm{zrc}}$ values.

\subsection{Clinopyroxene Sr and Nd Isotopes of the Dariv Igneous Complex}

$\mathrm{Rb} / \mathrm{Sr}$ ratios are low in the clinopyroxenes (0.001 to 0.014), making measured $\mathrm{Sr}$ isotope ratios relatively insensitive to radiogenic ingrowth of ${ }^{87} \mathrm{Sr}$. Initial ${ }^{87} \mathrm{Sr} /{ }^{86} \mathrm{Sr}$ values for most clinopyroxene separates are relatively uniform, varying between 0.7050 and 0.7056 , except for sample MO-10-392 with a higher value of 0.7061 (Fig. 4). These ${ }^{87} \mathrm{Sr} /{ }^{86} \mathrm{Sr}$ values are slightly "enriched" compared to the value of the Bulk Earth at $502 \mathrm{Ma}\left(0.7039\right.$, using present day chondritic ${ }^{87} \mathrm{Sr} /{ }^{86} \mathrm{Sr}$ value of 0.7045 , DePaolo and Wasserburg, 1976). Initial ${ }^{143} \mathrm{Nd} /{ }^{144} \mathrm{Nd}$ values vary between 0.51173 to 0.51201 , corresponding to initial $\varepsilon_{\mathrm{Nd}}$ values of 0.5 to -5.1 , which are similar to or less depleted compared to CHUR (Fig. 4a). Again, MO10-392 is distinct from other samples with the least radiogenic clinopyroxene initial $\varepsilon_{\mathrm{Nd}}$ value of -5.1 
Notably, sample MO-10-392 also contains the highest analyzed $\delta^{18} \mathrm{O}$ mineral values for ultramafic cumulates from the Dariv Igneous Complex (Fig. 3b, 4b).

\section{ANALYSIS OF NATURAL DATA}

\subsection{Preservation of Magmatic $\delta^{18} \mathrm{O}$ Values}

When minerals preserve their magmatic $\delta^{18} \mathrm{O}$ values their oxygen isotope compositions are better indicators of the $\delta^{18} \mathrm{O}$ value of the coexisting melt than whole rock $\delta^{18} \mathrm{O}$ values. For example, the $\delta^{18} \mathrm{O}$ value of the whole rock sample could deviate from that of melt if the rock sample either 1) represents accumulated minerals or 2) has experienced secondary alteration by surface waters, a metasomatic melt, or a supercritical fluid. We believe the effects of secondary alteration are minimal due to the unaltered nature of the samples chosen, careful petrographic inspection to exclude altered or inclusion-bearing minerals, cleaning procedures in an ultrasonic bath and pre-fluorination of grains before extraction of oxygen (see Day et al., 2012) and the lack of steep positively-sloped non-equilibrium arrays on mineralpair $\delta{ }^{18}$ O plots indicative of exchange with an external fluid (Gregory et al., 1989) (Fig. 5). However, previous studies show that even if secondary alteration is minimal, sub-solidus re-equilibration of oxygen isotopes among constituent minerals can occur in slowly cooled plutonic rocks through diffusive exchange (Giletti, 1986; Eiler et al., 1992; Eiler et al., 1993; Valley, 2001). The ability of a mineral to preserve its magmatic $\delta^{18} \mathrm{O}$ value depends on the cooling rate, the self-diffusivity of oxygen in the mineral, the grain size and shape of the mineral, and the mineral modal abundance. In general, refractory minerals such as olivine, zircon, and garnet with low oxygen self-diffusivities are more likely to preserve magmatic $\delta^{18} \mathrm{O}$ values than minerals such as $\mathrm{K}$-feldspar, plagioclase, and biotite in which oxygen diffuses more rapidly (Bindeman, 2008). For example, unaltered forsteritic olivine and zircon are characterized by low oxygen diffusivities (e.g., $3.3 \times 10^{-20} \mathrm{~m}^{2} / \mathrm{s}$ (Dohmen et al., 2002) and $1.9 \times 10^{-19} \mathrm{~m}^{2} / \mathrm{s}$ (Watson and Cherniak, 1997) at $1200^{\circ} \mathrm{C}$, respectively). Clinopyroxene has slightly higher oxygen self-diffusivities than olivine at a given temperature $\left(6.6 \times 10^{-20}\right.$ and $\mathrm{m}^{2} / \mathrm{s}$ at $1200^{\circ} \mathrm{C}$, Ingrin et al., 2001), whereas feldspar, quartz, and biotite have much higher oxygen self-diffusivities $\left(10^{-16}\right.$ to $10^{-18} \mathrm{~m}^{2} / \mathrm{s}$ at 500 to $900^{\circ} \mathrm{C}$ ) (Giletti et al., 1978; Giletti and Yund, 1984; Fortier and Giletti, 1991). Orthopyroxene oxygen self-diffusivities have not been thoroughly investigated.

Dodson's concept of a closure or blocking temperature below which diffusive exchange effectively ceases may be applied to oxygen isotopes (Dodson, 1973; Giletti, 1986). Although, this concept was established based on significantly simplified assumptions and more sophisticated Fast Grain Boundary models have been developed (Eiler et al., 1992), closure temperatures can place first order constraints on isotopic equilibration potential among different minerals. Closure temperatures will be higher for minerals with smaller oxygen diffusivities and larger grain sizes that experience rapid cooling. Using the diffusivities cited in the previous paragraphs, calculated closure temperatures for olivine and clinopyroxene grains of $0.1-0.5 \mathrm{~mm}$ in radius, typical of that observed in the studied sequences, at 
relatively slow cooling rates for upper crustal intrusions of $10-100^{\circ} \mathrm{C}$ per million years are $\sim 1060-1340{ }^{\circ} \mathrm{C}$ for olivine and $\sim 970-1310^{\circ} \mathrm{C}$ for clinopyroxene. Similarly, for a zircon approximated as a $50 \mu \mathrm{m}$ thick slab, calculated closure temperatures are $1190-1290^{\circ} \mathrm{C}$ at the same range of cooling rates. Conversely, similarly sized grains of quartz, biotite, and albite cooled at the same rates have much lower closure temperatures of $\sim 340-640^{\circ} \mathrm{C}$. Therefore, in the analyzed ultramafic samples from the Dariv Igneous Complex, olivine was the first mineral to close to isotopic exchange, then clinopyroxene, and lastly biotite. In the more evolved lithologies, zircon is the most robust recorder of magmatic $\delta^{18} \mathrm{O}$ values.

Likely none of the measured per mil differences in $\delta^{18} \mathrm{O}$ between minerals from Dariv and Bushveld record crystallization temperatures, as all the minerals (with the exception of potentially olivine and zircon) formed above their closure temperatures. Indeed, temperatures calculated from mineralmineral per mil differences are generally not in agreement between different mineral pairs from the same sample, suggesting subsolidus equilibration of more susceptible minerals. However, preserved mineralmineral per mil differences broadly preserve magmatic temperatures (Fig. 5), suggesting that mineral values did not experience significant isotopic re-equilibration. For the Bushveld analyses, three opx-cpx and three plag-ol mineral pairs yield an average of $+0.32 \pm 0.11 \%$ and $+1.75 \pm 0.15 \%$ o $(1 \sigma)$, corresponding to temperatures of $1010 \pm 230^{\circ} \mathrm{C}$ and $860 \pm 40^{\circ} \mathrm{C}$, respectively, using the mineral-mineral fractionations of Chiba et al., (1989) and Rosenbaum et al., (1994). $\Delta_{\text {opx-cpx }}$ values are within the range calculated for mantle xenolith opx-cpx pairs $(0.11 \pm 0.31 \%$ o $(1 \sigma)$; Mattey et al., 1994), but on the higher side, consistent with lower equilibration temperatures. $\Delta_{\text {plag-ol }}$ values are elevated above those observed in previous studies from basalts (e.g., $0.65 \pm 0.14 \%$, Eiler et al., 2000), but larger fractionations are reasonable during late stage crystallization of fayalitic olivine from more evolved, low temperature melts. Six clinopyroxeneolivine and ten clinopyroxene-biotite per mil differences were determined for the Dariv Igneous Complex. MO-12-21, MO-10-394, MO-10-392, and MO-11-8 preserve positive $\Delta_{\text {cpx-ol }}$ values $(0.22,0.27,0.79$, $0.63 \%$, respectively), which are similar to those determined for mantle xenoliths $(0.40 \pm 0.17 \%$ o $(1 \sigma)$; Mattey et al., 1994) and phenocrysts pairs from arc volcanics (e.g., Thirwall et al., 1996; Vroon et al., 2001; Baker et al., 2000). For two samples (MO-10-396 and MO-10-323) $\Delta_{\text {cpx-ol }}$ values are negative, suggesting re-equilibration of one or both phases. $\Delta_{\text {cpx-bt }}$ are generally more consistent (-0.12 to $0.54 \%$ ). There is little comparator oxygen isotope data for clinopyroxene-biotite pairs from other natural samples, however, phlogopite-clinopyroxene pairs from hydrated mantle peridotites yield $\Delta_{\text {cpx-bt }}$ values of - 0.5 to +0.1 (Ionov et al., 1994; Chazot et al., 1997), which are similar to the values observed in the Dariv Igneous Complex. Thus, it appears that mineral-mineral magmatic fractionations were broadly preserved with limited closed-system re-equilibration for some samples.

An important step in this study to assess which minerals are the most likely to preserve magmatic oxygen isotope values in order to reconstruct the oxygen isotope evolution of their equilibrium melts. Due to variability in $\mathrm{O}$ diffusivities and thus closure temperatures, the reliability of $\delta^{18} \mathrm{O}$ values of minerals to reflect that of coexisting melt is in the order of zircon $\cong$ olivine > clinopyroxene/orthopyroxene > quartz > 
feldspar > biotite. This is perhaps best reflected in the particularly high $\delta^{18} \mathrm{O}_{\mathrm{qtz}}$ values from the Dariv Igneous Complex, which likely preserve increases in $\delta^{18} \mathrm{O}$ due to subsolidus reequilibration due to rapid $\mathrm{O}$ self diffusion in quartz (Giletti and Yund, 1984). In contrast, preservation of magmatic $\delta^{18} \mathrm{O}$ values in olivine and pyroxene would have been enhanced by their relatively large crystal size $(0.5-1 \mathrm{~mm}$ in diameter). Zircon has been shown to preserve a reliable record for magmatic oxygen isotope ratios if radiation damage is limited (Valley, 2003; Wang et al., 2014; Gao et al., 2014). Un-published in-situ U$\mathrm{Pb}$ LA-ICPMS analyzes for zircons from the Dariv Igneous Complex yield predominantly concordant ages (>95\% of analyses), suggesting limited loss of $\mathrm{Pb}$ due to radiation damage. Further, SIMS analyses were focused on domains of bright oscillatory magmatic zoning observed in CL imagery and darker regions characteristic of radiation damage were avoided. Analyses with elevated ${ }^{16} \mathrm{OH} /{ }^{16} \mathrm{O}$ ratios, potentially indicative of radiation-damaged domains in zircons (Wang et al., 2014), were discarded and

not included in averages. We therefore place greatest confidence in the $\delta^{18} \mathrm{O}_{\mathrm{ol}}$ and $\delta^{18} \mathrm{O}_{\mathrm{pyx}}$ values in the mafic and ultramafic rocks and $\delta^{18} \mathrm{O}_{\mathrm{zrc}}$ values in the more evolved lithologies as being indicative of magmatic values.

\section{2. $\delta^{18} \mathrm{O}$ Values of Equilibrium Melt}

A few of the more evolved samples from the Dariv Igneous Complex were suggested to be solidified melts based on trace element systematics suggesting a lack of feldspar accumulation (Bucholz et al., 2014b). Therefore, their whole rock compositions can be considered as representative of equilibrium melt compositions. However, for minerals analyzed from cumulate samples, we used an indirect method to calculate the equilibrium melt major element composition and $\delta^{18} \mathrm{O}$. For the UUMZ of the Bushveld Complex we used a previously modeled LLD using the MELTS software (VanTongeren et al. 2010; Ghiorso and Sack 1995) that is correlated with stratigraphic height above the Pyroxenite Marker. This model yields equilibrium major element composition of the melt, as well as, magmatic temperatures for samples throughout UUMZ. For the Dariv Igneous Complex, we based our major element concentrations and temperatures on experimentally determined melt compositions for crystallizing hydrous high-K basalts (Esperanca \& Holloway 1987; Righter \& Carmichael 1996) similar to those parental to the Dariv Igneous Complex. This was done to ensure appropriate temperatures and $\mathrm{SiO}_{2}$ contents of the equilibrium melt. To obtain an equilibrium melt composition, we first implemented mineral-melt Fe/Mg exchange coefficients of 0.3 for olivine (Roeder and Emslie, 1970) and 0.23 for clinopyroxene (Sisson and Grove, 1993), to estimate an equilibrium melt Mg\# for each analyzed cumulate sample. For example, sample MO-12-21 from the Dariv Igneous Complex has $\mathrm{Mg \#}_{\mathrm{cpx}}$ of 91.4, corresponding to an equilibrium melt composition with an $\mathrm{Mg \#} \mathrm{of} \sim 71$. Using calculated melt Mg\#, we then linearly extrapolated the experimental glass compositions (from Righter \& Carmichael, 1996 and Esperanca and Holloway, 1987) to match the calculated $\mathrm{Mg} \#$ and to obtain equilibrium melt compositions and temperatures (see Figure A.5). For liquid-like samples we estimated temperatures from experimental 
glasses with similar $\mathrm{SiO}_{2}$ concentrations. As temperature and $\mathrm{SiO}_{2}$ content are the most important magmatic variables in calculating mineral-melt fractionation factors, the other major element variations in the equilibrium glasses will not affect the calculations significantly.

Following the suggestion of previous workers (e.g. Eiler, 2001), we then treated the melt composition as a mixture of CIPW normative minerals to calculate $\Delta^{18} \mathrm{O}_{\text {min-melt }}$ Temperature-dependent quartz-mineral fractionation factors used in these calculations are given in Appendix Table A.4. The majority of fractionation factors are based on experimentally determined mineral-mineral fractionations (Clayton et al., 1972; Chiba et al., 1989; Fortier and Lüttge, 1995; Chacko et al., 1996) and summarized in Chacko et al. (2001) or Valley (2003). The notable exceptions are quartz fractionations with zircon and garnet, which were empirically calibrated by Valley et al., (2003), and K-feldspar, nepheline, amphiboles, enstatite, spinel, and ilmenite which are based on theoretical considerations (Zheng, 1991; Zheng, 1993a; Zheng, 1993b) due to the lack of experimental data for these phases. Although this is not ideal, until more detailed studies on mineral-mineral fractionation factors are experimentally determined, we are implementing what we believe are the best available values.

Calculated mineral-melt fractionations used for each sample are given in Table 5. These values are similar to those from direct experimental constraints on mineral-melt fractionation factors (Stolper and Epstein, 1991; Palin et al., 1996; Appora et al., 2003) and observed in coexisting glasses and phenocrysts in natural samples (Eiler et al., 1995; 2000). For example, the calculated $\Delta_{\text {ol-melt }}$ vary from 0.6 to $-1.0 \%$ at temperatures of $1090-1200^{\circ} \mathrm{C}$. These values are in good agreement with the experimentally predicted fractionations for olivine-basalt (-0.4\%o) and olivine-Na-rich melilite (-0.8\%o) at magmatic temperatures (see Fig. 5b of Appora et al. 2003). They also fall within the range of naturally determined olivine-basaltic glass fractionations. For example, Eiler et al., (2000) found an average olivine-glass fractionation of $-0.36 \pm 0.22 \%$ for oceanic arc lavas, whereas -0.8 to $-1.0 \%$ olivine-glass fractionation were observed in lavas from the Lau Basin and Kermadec island arcs (Macpherson and Mattey, 1998; Macpherson et al., 1998). Calculated $\Delta_{\text {ol-melt }}$ values only decrease significantly below $1 \%$ when the equilibrium melt $\mathrm{SiO}_{2}$ contents increase above $\sim 60 \mathrm{wt} . \%$.

Using the calculated equilibrium melt $\Delta^{18} \mathrm{O}_{\text {min-melt }}$ and the analyzed $\delta^{18} \mathrm{O}_{\text {min }}$, we calculate an equilibrium $\delta^{18} \mathrm{O}_{\text {melt }}$. The results of our calculations indicate that equilibrium $\delta^{18} \mathrm{O}_{\text {melt }}$ values increase by 1$1.5 \%$ and $\sim 2-3 \%$ with increasing $\mathrm{SiO}_{2}$ content of the melt from 50 to $\sim 70 \mathrm{wt} . \%$ for the Bushveld Complex and Dariv Igneous Complex, respectively (Fig. 6b\&d). For the Bushveld Complex, there is an initially flat trajectory in $\delta^{18} \mathrm{O}_{\text {melt }}$ as the melt $\mathrm{Mg \#} \mathrm{decreases} \mathrm{from} 40$ to $\sim 25$, in agreement with crystallization of phases with $\delta^{18} \mathrm{O}$ values similar to that of the equilibrium melt (plagioclase $(\mathrm{An}=\sim 50$ $70)$ and pyroxenes). At lower $\mathrm{Mg \#}(<25)$ the slope of the $\delta^{18} \mathrm{O}_{\text {melt }}$ trajectory begins to increase, due to both the crystallization of low- $\delta{ }^{18} \mathrm{O}$ phases, such as fayalite and magnetite, and the higher $\mathrm{SiO}_{2}$ contents in the melt, which results in larger mineral-melt fractionations. For the Dariv Igneous Complex modeled melt 
composition an abrupt increase in the calculated $\delta^{18} \mathrm{O}_{\text {melt }}$ of $1-2 \%$ is observed at a melt $\mathrm{Mg} \#$ of 50-55 (Fig. 6d), which coincides with an increase in $\mathrm{SiO}_{2}$ content of the melt from $\sim 55$ to 60 wt. $\%$.

\subsection{Parental melt $\delta^{18} \mathrm{O}$ values}

We estimate a range of $\delta^{18} \mathrm{O}$ values of the initial parental melts to be in equilibrium with $\delta^{18} \mathrm{O}_{\text {min }}$ in the least evolved cumulates from the two sequences. For the Bushveld UUMZ, the gabbronorite B06062 is the most primitive cumulate sample $\left(\mathrm{Mg} \#_{\mathrm{WR}}=74.7, \mathrm{Mg}_{\mathrm{cpx}}=80\right)$. Using B06-062 average orthopyroxene, clinopyroxene, and plagioclase $\delta^{18} \mathrm{O}$ values $(6.18 \pm 0.15 \%$, $5.76 \pm 0.23 \%$, and $6.77 \pm 0.01 \%$ o $(2 \sigma)$, respectively), we calculated an equilibrium melt composition of 6.1-6.6\%, using $\Delta_{\text {opx-melt }}=-0.2 \%$, $\Delta_{\text {cpx-melt }}=-0.3 \%$, and $\Delta_{\text {plag-melt }}=+0.2 \%$. For the Dariv Igneous Complex the most primitive cumulate sample is the phlogopite wehrlite MO-12-21 $\left(\mathrm{Mg} \#_{\mathrm{WR}}=91.5, \mathrm{Mg} \#_{\mathrm{ol}}=87\right)$. The $\delta^{18} \mathrm{O}_{\mathrm{ol}}$ and $\delta^{18} \mathrm{O}_{\mathrm{cpx}}$ values for MO-12-21 are $6.51 \pm 0.01 \%$ and $6.73 \pm 0.01 \%$ ( $2 \sigma)$, respectively, which correspond to melt values of 7.1-7.4\%o using $\Delta_{\text {ol-melt }}=-0.6 \%$ and $\Delta_{\text {cpx-melt }}=-0.2 \%$. In addition, $\delta^{18} \mathrm{O}_{\mathrm{zrc}}$ values from a near-primitive

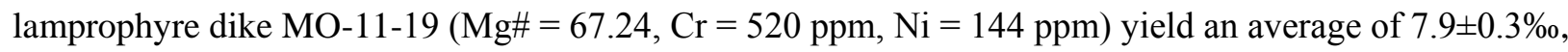
suggesting derivation from a source region with elevated $\delta^{18} \mathrm{O}$ values.

Therefore, parental melt $\delta^{18} \mathrm{O}$ values of 6.1-6.6\% and 7.1-7.4\%o appear to be reasonable values for the UUMZ of the Bushveld Complex and the Dariv Igneous Complex, respectively. These mineral and calculated melt values are above values from mid-ocean ridge basalts and other uncontaminated mantle sources. In general, studies of mid-ocean ridges and peridotite xenoliths from intracontinental and ocean island lavas portray an upper mantle that demonstrates local variability of small (0.1-0.2\%o) degrees, but on average has mineral values of the following: $5.2 \pm 0.3 \%$ for olivine, $5.6 \pm 0.5 \%$ o for clinopyroxene, and 5.3 $\pm 0.6 \%$ for zircon (Mattey et al., 1994; Ionov et al., 1994; Chazot et al., 1997; Valley et al., 1998; Eiler et al., 2000; Cavosie et al., 2009; Grimes et al., 2011) (Fig. 7). These average mineral $\delta^{18} \mathrm{O}$ values are in magmatic equilibrium with basaltic melts of 5.6-5.7\% at mantle temperatures, in agreement with $\delta^{18} \mathrm{O}$ values obtained for basaltic glasses from mid-ocean ridges $\left(5.35-6.05 \%\right.$, Ito et al., 1987). The $\delta^{18} \mathrm{O}$ values for parental melts of the Bushveld Complex calculated here are similar to, but slightly lower than those inferred from previous studies for the Main and Upper Zones of the Bushveld Complex (6.8-7.5\%; Schiffries and Rye, 1989; Harris and Chaumba, 2001; Harris et al., 2005; see Appendix for more detailed discussion).

The calculated $\delta^{18} \mathrm{O}$ values for the parental melts of the Dariv Igneous Complex are significantly elevated from that of "normal" mantle-derived melts. In fact, the $\delta^{18} \mathrm{O}_{\mathrm{ol}}$ values are some of the highest ever documented for igneous olivines (Fig. 7). Although we cannot rule out crustal contamination of the parental melts after extraction from the mantle, but before crystallization of the cumulate sequence, assimilation must have been minimal as the most primitive cumulates have $\mathrm{Mg}_{\mathrm{ol}}$ values close to mantle values, as well as, high $\mathrm{Ni}$ and $\mathrm{Cr}$ contents in olivine and clinopyroxene. Therefore, the elevated $\delta^{18} \mathrm{O}_{\mathrm{ol}}$ and inferred $\delta^{18} \mathrm{O}_{\text {melt }}$ values are likely to be at least partially due to a large contribution of subducted 
crustal material to the mantle wedge from which the parental melts were generated (Bucholz et al., 2014a,b).

\section{Model Results and Comparison to Natural Data}

\subsection{Model Results for the UUMZ, Bushveld Complex and Dariv Igneous Complex}

Beginning with a parental $\delta^{18} \mathrm{O}_{\text {melt }}$ value of 6.0-6.4\%, the closed-system fractional crystallization model reproduces the $\sim 1.0 \%$ increase in $\delta^{18} \mathrm{O}_{\text {melt }}$ inferred from minerals for the UUMZ (Fig. 6b). The consistency between our model of closed-system fractionation and the mineral data suggests that the UUMZ of the Bushveld Complex did not experience significant input of material with distinctive $\delta^{18} \mathrm{O}$ values from the crystallizing melt, consistent with previous Sr isotopic studies of the complex (Sharpe 1985; Kruger et al. 1987) (Fig. 2b).

For the Dariv Igneous Complex, the closed-system fractional crystallization model is not able to reproduce the $\sim 2-3 \%$ increase observed for the calculated $\delta^{18} \mathrm{O}_{\text {melt }}$ as its silica content increases from $\sim 50$ to $70 \mathrm{wt} . \%$ (Fig. 8d). This indicates that either (1) olivine, clinopyroxene, and zircon data in the more evolved lithologies were preferentially affected by subsolidus equilibration or alteration resulting in higher $\delta^{18} \mathrm{O}$ values or (2) that the crystallizing melt assimilated high $\delta^{18} \mathrm{O}$ material during the later stages of its fractionation. Although we cannot rule out option 1, significant subsolidus equilibration is unlikely due to the refractory nature of the minerals and their high closure temperatures (see section 6.1). To assess possibility 2, we examine the oxygen and $\mathrm{Sr}-\mathrm{Nd}$ isotope data in clinopyroxenes for a correlation, which is compelling evidence for crustal contamination (e.g., Taylor, 1980; James, 1981). Initial ${ }^{87} \mathrm{Sr} /{ }^{86} \mathrm{Sr}$ ratios in analyzed clinopyroxenes from the more primitive cumulates are generally uniform $(0.7050$ 0.7056) with corresponding $\delta^{18} \mathrm{O}$ values of 6.7-7.7\%o. Sample MO-10-392, however, has distinctly higher clinopyroxene $\delta^{18} \mathrm{O}$ and initial ${ }^{87} \mathrm{Sr} /{ }^{86} \mathrm{Sr}$ ratio values (8.6\% and 0.7061 , respectively) and lower $\varepsilon \mathrm{Nd}(\mathrm{t})$, suggesting incorporation of "crustal", high $\delta^{18} \mathrm{O}$ material before or concomitantly during crystallization of this sample (Fig. 4).

Thus, assimilation of high $\delta^{18} \mathrm{O}$, crustal material appears to have occurred in the Dariv Igneous Complex. We do not attempt to take into account the effect of assimilation on the modeled major element LLD and calculated $\delta^{18} \mathrm{O}$ melt trajectory. Assimilation will have little effect on the major element LLD in that it promotes the formation of cumulus minerals already crystallizing (Taylor, 1980). Further, major element trends are controlled by the positions of multi-component eutectics and cotectics on applicable phase diagrams. Thus, although assimilation may speed up differentiation through induced cooling of the magma and increase the proportions of late differentiated melts, major element concentrations in these melts will not be strongly affected (Bowen, 1928; Taylor, 1980). Based on the geology of the area and field relationships there are no obvious candidates for the high $\delta^{18} \mathrm{O}$, high ${ }^{87} \mathrm{Sr} /{ }^{86} \mathrm{Sr}$, and low $\varepsilon_{\mathrm{Nd}}$ assimilated material (Bucholz et al., 2014a). In particular, the exposed Dariv Igneous Complex intrudes serpentinized harzburgite-dunite with low $\mathrm{SiO}_{2}$ and a bulk rock $\delta^{18} \mathrm{O}$ of $3.87 \%$, which would produce 
decreasing $\delta^{18} \mathrm{O}$ and $\mathrm{SiO}_{2}$ trends. One possibility is that late stage recharge by a high- $\delta^{18} \mathrm{O}$, crustallycontaminated melt is responsible for the observed increase in $\delta^{18} \mathrm{O}$, but the field and whole rock geochemical evidence for it is cryptic. As such, we do not quantitatively model AFC processes due to the lack of end member constraints.

\subsection{Model Results for all Studied LLDs}

Model results for the fractionation model presented in Section 3 are shown in Figures 8 and 9. The hydrous calc-alkaline to high-K LLDs generally display steeper trajectories than anhydrous to waterpoor tholeiitic LLDs at higher melt fractions. For example, the hydrous sequences increase by $0.5-0.6 \%$ over $\mathrm{F}=1.0$ to 0.4 , whereas the anhydrous ones increase by $<0.3 \%$ over this same interval (Fig. $8 \mathrm{~b}, 9)$. At $\mathrm{F}<0.4$, the slopes of the hydrous sequence trajectories increase appreciably with average values of $0.4 \%$ increases per tenth of melt fraction crystallized. Notably this coincides with a sharp increase in $\mathrm{melt}^{\mathrm{SiO}} \mathrm{O}_{2}$ concentrations (Fig 8a,9). Overall increases for the hydrous LLDs are 1.2-1.5\%o from $F=1$ to 0.1 . Conversely, the slopes of the water-poor and anhydrous melt trajectories do not significantly increase until $\mathrm{F}<0.2$, at which point they vary between 0.2 to $1 \%$ increase per tenth of melt fraction crystallized (Fig. 8b,9). Again this sharp increase occurs simultaneously with an enrichment in $\mathrm{SiO}_{2}$ in the melt (Fig. $8 \mathrm{a}, 9)$. Total increases across the modeled crystallization intervals $(\mathrm{F}=1$ to 0.1$)$ vary between $0.5-1.0 \%$. No systematic trends are observed in the melt trajectory slopes with pressure or oxygen fugacity of the studied systems, however due to the multivariate nature of these studied systems, it is difficult to assess the independent controls of these specific variables.

\section{CONTROLS ON TRAJECTORY OF $\delta^{18}$ O VALUES OF CRYSTALLIZING MELTS}

The modeled closed system crystallizing melt trajectories for the six experimental and natural LLDs determined here allows us to assess controls on $\delta^{18} \mathrm{O}$ variations during fractional crystallization of different parental melts. Our results indicate that $\delta^{18} \mathrm{O}_{\text {melt }}$ values may increase significantly by $\sim 1.0-1.5 \%$ as melt $\mathrm{SiO}_{2}$ changes from $\sim 50$ to $70 \mathrm{wt} . \% \mathrm{SiO}_{2}$ (or $\mathrm{F}=1$ to 0.1 ) due to closed-system fractional crystallization alone (Fig. 8). The specific $\delta^{18} \mathrm{O}$ trajectory of a crystallizing melt will depend on (1) the temperature of crystallization, (2) the composition of the evolving melt (and thus the degree of differentiation), and (3) the crystallizing phase assemblage.

(1) The temperature of crystallization is critically important as mineral-melt fractionations increase in absolute magnitude with decreasing temperature. Liquidus and solidus temperatures for melts vary greatly depending on the major element composition of the melt, but also critically the water content. For example, an addition of $3 \mathrm{wt} . \% \mathrm{H}_{2} \mathrm{O}$ to a basaltic melt will reduce the liquidus temperature by $\sim 100^{\circ} \mathrm{C}$ (Médard and Grove, 2007). Similarly the solidus of a eutectic granite may vary from $\sim 900^{\circ} \mathrm{C}$ for an anhydrous granite to $\sim 650^{\circ} \mathrm{C}$ for a water-saturated one (Ebadi and Johannes, 1991; Holtz and Johannes, 1994). The modeled experimental systems in this study have liquidus temperatures that vary from $1330^{\circ} \mathrm{C}$ 
(anhydrous basalt at $1 \mathrm{GPa}$, Villiger et al., 2004) to $1170^{\circ} \mathrm{C}$ (hydrous basalt at $0.7 \mathrm{GPa}$, Nandedkhar et al., 2014). At later stages of differentiation and more evolved melt composition (65 wt.\% $\left.\mathrm{SiO}_{2}\right)$ the anhydrous melt is at $1070^{\circ} \mathrm{C}$, whereas the hydrous one is at $800^{\circ} \mathrm{C}$. In general, mineral-melt fractionations will be larger at lower temperatures. Consequently, if bulk mineral-melt fractionations are negative, crystallizing wet, cooler melts will result in larger increases in $\delta^{18} \mathrm{O}$ per degree of crystallization than for dry, hot melts. This prediction is observed in the closed-system model results. The modeled hydrous, relatively cool crystallizing system has a steeper trajectory in $\delta^{18} \mathrm{O}_{\text {melt }}-\mathrm{F}$ space than anhydrous, hot melts, particularly at lower melt fractions (Figs. 8b, 9).

(2) The trajectory of $\delta^{18} \mathrm{O}_{\text {melt }} \mathrm{v}$. melt fraction will depend on the composition of the remaining melt and, in particular, when enrichment in its silica content occurs. Increases in melt $\mathrm{SiO}_{2}$ content will result in preferential enrichment of ${ }^{18} \mathrm{O}$ in the melt relative to crystallized minerals. In dry "tholeiitic" systems silica-enrichment generally happens late in the fractionation process $(\mathrm{F} \leq 0.20)$, whereas for the hydrous melts silica-enrichment occurs earlier (Miyashiro, 1974) (Figs. 8a, 9). Relatively early silica enrichment during fractional crystallization is driven by the crystallization of silica-poor minerals such as hornblende, garnet, An-rich plagioclase, and oxides for the calc-alkaline series (Sisson and Grove, 1993; Müntener et al., 2001; Sisson et al., 2005; Alonso-Perez et al., 2009; Jagoutz, 2010; Nandedkar et al., 2014; Melekhova et al., 2015) or biotite, apatite, and oxides from high-K hydrous melts (Esperança and Holloway, 1987; Righter and Carmichael, 1996; Bucholz et al. 2014b). Often silica enrichment occurs rather rapidly upon multiple saturation of these low-Si minerals with other crystallized phases (e.g., plagioclase or pyroxenes) (Melekhova et al., 2013; Blatter et al., 2013; Nandedkar et al., 2014). The effect of an early increase in silica content is observed in the increase of modeled $\delta^{18} \mathrm{O}$ in the hydrous experimental melt at higher $\mathrm{F}$ due to saturation of amphibole and magnetite (Fig. 9). Conversely, the dry/water-poor systems experience large crystallization periods of plagioclase and pyroxenes, resulting in limited $\mathrm{SiO}_{2}$ enrichment. This is observed in the modeled anhydrous systems where significant $\delta^{18} \mathrm{O}_{\text {melt }}$ increases occur only in the late stages of crystallization $(\mathrm{F} \leq 0.20)$ when melt $\mathrm{SiO}_{2}$ increases above 60 wt.\%.

(3) A number of factors including melt composition and water content, as well as the temperature, pressure, and oxidation state of crystallization will affect the crystallized mineral assemblage, which in turn affects the magnitude of $\delta^{18} \mathrm{O}$ increase. Higher water contents generally increase the thermal stability of low $\delta^{18} \mathrm{O}$ minerals, such as olivine, Fe-Ti oxides, garnet, and hornblende, whereas the stability of relatively high $\delta^{18} \mathrm{O}$ plagioclase decreases (Nicholls and Ringwood, 1973; Sisson and Grove, 1993; Müntener et al., 2001; Alonso-Perez et al., 2009). In addition, high water contents lead to the crystallization of anorthitic plagioclase (Sisson and Grove, 1993), which will have lower $\delta^{18} \mathrm{O}$ values than coexisting albitic plagioclase. Elevated crystallization pressures will stabilize garnet while suppressing plagioclase and olivine crystallization, thereby having variable effects on the magnitude of fractionation between cumulate minerals and the crystallizing melt (Sisson and Grove, 1993; Müntener et al., 2001; 
Alonso-Perez et al., 2009). The oxidation state of a crystallizing melt will also variably affect the thermal stability of ${ }^{18} \mathrm{O}$-depleted minerals as higher oxygen fugacities reduce the stabilities of olivine and Fe-rich amphibole, but increase that of magnetite (Nitsan, 1974; Toplis and Carroll, 1995; Sisson et al., 2005). Notably, fayalitic olivine crystallizes at relatively low temperatures and melt fractions in the UUMZ of the Bushveld Complex and in experiments on relatively dry tholeiitic basalts (Whitaker et al., 2008). Low temperature crystallization of olivine from melts having relatively high $\mathrm{SiO}_{2}$ contents causes pronounced increases in $\delta^{18} \mathrm{O}_{\text {melt }}$ at low melt fractions in these systems (Figs. 8b, 9).

In summary, first order differences in the trajectory of $\delta^{18} \mathrm{O}$ increases during differentiation can be deduced for hydrous versus dry melts due to differences in $\mathrm{T}-\mathrm{SiO}_{2}-\mathrm{F}$ relationships. Hydrous melts, typical of subduction zone magmatism, will generally show large, earlier (i.e., at higher F) increases in $\delta^{18} \mathrm{O}$ during fractional crystallization due to enhanced high temperature stability of low $\delta^{18} \mathrm{O}$ phases, lower magmatic temperatures, and early silica-enrichment as compared to dry melts. Dry tholeiitic sequences only experience large increases in $\delta^{18} \mathrm{O}$ during the late stages of crystallization.

\section{IMPLICATIONS FOR INTERPRETATION OF $\delta^{18}$ O VALUES OF THE ROCK RECORD}

\subsection{Range of $\delta^{18} O$ values permissible through fractional crystallization of mantle derived melts}

Using our modeled melt $\delta^{18} \mathrm{O}$ trajectories, we can calculate the range of $\delta^{18} \mathrm{O}_{\text {melt }}$ values admissible through fractional crystallization of mantle-derived melts and compare this to $\delta^{18} \mathrm{O}$ values observed in upper crustal granitoids. In order to apply our model to the natural rock record, we must first choose an appropriate range in $\delta^{18} \mathrm{O}$ values of mantle-derived melts. Many detailed studies of mantle peridotites, zircons from kimberlites, and mid-ocean ridge basalts and plagiogranites portray an upper mantle in midocean ridge and certain cratonal settings that is locally variable, but on average has mineral $\delta^{18} \mathrm{O}$ values of the following: $5.2 \pm 0.3 \%$ for olivine, $5.6 \pm 0.5 \%$ for clinopyroxene, and $5.3 \pm 0.6 \%$ for zircon

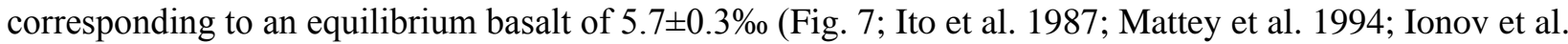
1994; Chazot et al. 1997; Valley et al., 1998; Eiler, 2001; Eiler et al. 2000b; Cavosie et al 2009; Grimes et al. 2011). These values are considered, "pristine" mantle values, with minimal influence of subducted or otherwise recycled crustal material. Assuming that most mid-ocean ridge basalts follow a relatively anhydrous and hot crystallization path, an increase of $\sim 1 \%$ would be expected during the course of fractional crystallization resulting in highly fractionated plagiogranite melts with maximum $\delta^{18} \mathrm{O}_{\text {melt }}$ values of $\sim 6.7 \%$ o (Fig. 10a).

However, to understand what range in $\delta^{18} \mathrm{O}$ values may be appropriate for parental melts to granitic intrusions in arc settings, we must examine the range of permissible mantle-derived values in subduction zones, which may be influenced by high $\delta^{18} \mathrm{O}$ subducted material. Early studies of oceanic arc lavas found that $80 \%$ of mineral $\delta^{18} \mathrm{O}$ analyses fell within $0.2 \%$ of the averages constrained for peridotites and MORBs (Eiler et al., 2000). Elevated $\delta^{18} \mathrm{O}_{\text {olivine }}$ values of up to $5.8 \%$ were ascribed to a flux of additional high $\delta^{18} \mathrm{O}$ aqueous fluid to their subarc source region. More recent studies of continental arcs, 
however, have demonstrated a much larger range in $\delta^{18} \mathrm{O}$ values of olivines from primitive arc basalts (Portynyagin et al 2007; Auer et al., 2009; Eiler et al., 2005; Johnson et al., 2009; Martin et al., 2011; Ruscitto et al., 2010; 2011). For example, olivine phenocrysts from high-Mg lavas ( $\mathrm{MgO}>9$ wt.\%) from Klyuchevskoy Volcano and other volcanic rocks from the Central Kamchatka Depression have $\delta^{18} \mathrm{O}$ values ranging from $\sim 5.6-7.6 \%$ corresponding to an equilibrium melt composition of 6.3-8.0\% (Auer et al., 2009; Dorendorf et al., 2000, Portnyagin et al., 2007). Although Auer et al., (2009) recognized that many of the analyzed olivines were recycled xenocrysts, they concluded based on major and trace element considerations of the olivines that their high $\delta^{18} \mathrm{O}$ values were derived from a subductioninfluenced peridotitic source region, not lower crustal assimilation. Lavas of central Mexico are also characterized by high $\delta^{18} \mathrm{O}_{\text {olivines }}$ values (Johnson et al., 2009; Straub et al., 2015) of up to 6.5\%o. Straub et al. (2015) demonstrated that olivine with high $\delta^{18} \mathrm{O}$ values also had high Ni contents and mantle-like ${ }^{3} \mathrm{He} /{ }^{4} \mathrm{He}$ values, suggesting that their host magma were near-primitive melts from a mantle modified by slab-derived crustal components. Similarly, elevated $\delta^{18} \mathrm{O}_{\text {olivine }}$ values of up to $6.1 \%$ have been reported for high-Mg lavas from the South Cascades (Martin et al., 2011), Central Oregon (Ruscitto et al., 2011; 2010), Mexico (Johnson et al., 2009), and Central America (Eiler et al., 2005). Due to the near primitive nature of these lavas or melts, significant elevation of $\delta^{18} \mathrm{O}$ values through intra-crustal contamination (i.e., within the crustal column) is not likely. As such, these are primary features of the lavas with a high $\delta^{18} \mathrm{O}$ contribution from subducted crustal material introduced to the mantle wedge.

Therefore, the assumption that unmodified mantle-derived melts must fall in the range of $5.7 \pm$ $0.2 \%$ and that minerals in equilibrium with these melts must have specific values (e.g. olivine $\sim 5.3 \%$ and zircon $\sim 5.2 \%$ ) must be broadened to include a wider range of values for primitive arc melts. If a relatively conservative range of $\delta^{18} \mathrm{O}$ values for primitive arc melts of 5.7 to $7.0 \%$ exists and increases in $\delta^{18} \mathrm{O}$ of $1.0-1.5 \%$ during fractional crystallization can occur, high silica melts with $\delta^{18} \mathrm{O}$ values of 6.7 to $8.5 \%$ can be produced through closed-system fractional crystallization alone (Fig. 8a). In addition, the hydrous, relatively cool nature of arc basalts would produce favor larger increases in $\delta^{18} \mathrm{O}$, similar to the trends calculated for Nandedkhar et al., 2014 or the Kohistan Arc in this study. This range in $\delta^{18} \mathrm{O}$ covers the majority of values from analyzed "I-type" granites, which are generally <10\%o (Harris et al., 1997; Taylor, 1978). Although issues exist with secondary alteration when interpreting plutonic whole rock $\delta^{18} \mathrm{O}$ data, the Sierra Crest Intrusive Suites (e.g. Tuolumne, John Muir) provide a nice example of increasing $\delta^{18} \mathrm{O}_{\mathrm{WR}}$ values with $\mathrm{SiO}_{2}$, which is consistent with the calc-alkaline fractionation trends calculated for a basalt with initial $\delta^{18} \mathrm{O}$ values 5.7-7.0\%o (Fig. 10b, Lackey et al. 2008). Zircons from these suites, which are more resilient to post-magmatic alteration, corroborate these trends demonstrating relatively subdued $\mathrm{d}^{18} \mathrm{O}$ values $\left(<6.5 \%\right.$ ) across a wide range in $\mathrm{SiO}_{2}$ whole rock values. These observations are consistent with studies proposing that significant proportion of the Cretaceous SNB were generated from melting of enriched lithospheric mantle beneath the eastern Sierra with limited involvement of metavolcanic or metasedimentary rocks (Coleman et al., 1992; Coleman and Glazner, 
1997; Lackey et al., 2008). Higher $\delta^{18} \mathrm{O}$ values than this would demand intra-crustal assimilation of high$\delta^{18} \mathrm{O}$ material, such as (meta-)sediments, that originally precipitated from or equilibrated with water at surface temperatures. This finding is in agreement with the elevated $\delta^{18} \mathrm{O}$ values $(10-13 \%)$ generally observed in peraluminous "S-type" granites, which are widely assumed to be largely derived from intracrustal melting of sedimentary rocks (Fig. 10b; Taylor, 1968; Harris et al., 1997; Lackey et al., 2006; O'Neil et al., 1977). Of course, any study investigating $\delta^{18} \mathrm{O}$ variations in the plutonic record would need to complement their oxygen isotope observations with radiogenic isotope data $(\mathrm{Sr}, \mathrm{Nd}, \mathrm{Pb})$ to unravel the history of assimilation. Here, we are simply discussing the hypothetical range that could be produced through closed-system fractional crystallization of mantle-derived melts from subduction zones.

\subsection{Implications for calculating melt $\delta^{18} O$ values from zircon $\delta^{18} O$ values}

Zircon is often selected to study oxygen isotope compositions of igneous rocks as it is highly retentive of magmatic $\delta^{18} \mathrm{O}$, offering an alternative approach to analyzing whole rock samples which may be affected by low temperature alteration (Valley, 2003; Page et al., 2007; Bindeman, 2008). In addition, although $\delta^{18} \mathrm{O}_{\text {melt }}$ will increase with progressive fractionation, $\delta^{18} \mathrm{O}_{\text {zircon }}$ will stay relatively constant due to the increase in $\Delta^{18} \mathrm{O}_{\text {melt-zrc }}$ as melt temperature decreases and its $\mathrm{SiO}_{2}$ content increases. For example, in the Tuolumne Suite of the Sierra Nevada $\delta^{18} \mathrm{O}_{\text {zrc }}$ values remain relatively constant at ( 6.1-6.3\%) while $\delta^{18} \mathrm{O}_{\mathrm{WR}}$ values vary from $\sim 7$ to $9 \%$ from $57-76 \mathrm{wt} . \% \mathrm{SiO}_{2}$ (Lackey et al., 2008). In order to use zircon as a proxy to estimate the original $\delta^{18} \mathrm{O}$ of the bulk magma (or whole rock), $\Delta^{18} \mathrm{O}_{\mathrm{WR}-\text { rrc }}$ must be known at various magmatic temperatures and melt compositions. Lackey et al., (2008) present an empirical equation relating $\Delta^{18} \mathrm{O}_{\mathrm{WR}-\text { zrc }}$ to bulk rock $\mathrm{SiO}_{2}$ wt.\% based on 297 rocks from the Sierra Nevada Batholith for which mineral modes, $\mathrm{SiO}_{2}$ content, and $\delta^{18} \mathrm{O}_{\mathrm{zrc}}$ were constrained. Knowing the abundances and equilibrium fractionation factors for the constituent minerals they calculated $\Delta^{18} \mathrm{O}_{\mathrm{WR}-\mathrm{zrc}}$ using a linearly extrapolated relationship between solidus temperature and $\mathrm{SiO}_{2}$ content. Importantly, they assumed that solidus temperatures decreased linearly from $900^{\circ} \mathrm{C}$ at 45 wt. $\% \mathrm{SiO}_{2}$ to $650^{\circ} \mathrm{C}$ at 78 wt. $\% \mathrm{SiO}_{2}(\mathrm{Fig} .10 \mathrm{a})$.

Although this was a useful first order approach to address $\Delta^{18} \mathrm{O}_{\text {WR-zircon }}$ variations for different melt compositions and temperatures, calculating $\Delta^{18} \mathrm{O}_{\text {WR-zircon }}$ in natural systems is certainly more nuanced. First, a linear correlation between $\mathrm{SiO}_{2}$ content and melt temperature is not observed from experimental studies, rather melt $\mathrm{T}-\mathrm{SiO}_{2}$ relationships are generally non-linear and are variable between melts of different compositions and crystallization conditions (Fig. 11a). Due to the assumed linearity between melt $\mathrm{SiO}_{2}$ and temperature and the proportionality of mineral-melt fractionation factors to $1 / \mathrm{T}^{2}$, it is not surprising that the Lackey et al., (2008) model produces a strong positive correlation between $\Delta^{18} \mathrm{O}_{\mathrm{WR}-\text { zircon }}$ and $\mathrm{SiO}_{2}$ content $\left(\mathrm{r}^{2}=0.98\right)$. Secondly, the solidus temperatures chosen for a low-silica gabbro $\left(900^{\circ} \mathrm{C}\right)$ versus a granite $\left(650^{\circ} \mathrm{C}\right)$ are in reality highly variable depending on pressure and water contents. For example, granite solidi can vary from $650-900^{\circ} \mathrm{C}$ depending on the water content of the granitic melt (Holtz and Johannes, 1994). 
In Figure $11 \mathrm{~b}$, we show the $\Delta^{18} \mathrm{O}_{\mathrm{WR}-\text { zircon }}$ relationship derived by Lackey et al., (2008) compared to those calculated using the model presented in this study. Notably, using the correlation proposed by Lackey et al., (2008) generally predicts larger $\Delta^{18} \mathrm{O}_{\text {WR-zircon }}$ values than those using our model. This is primarily due to the significantly lower temperature at a given $\mathrm{SiO}_{2}$ content used by Lackey et al., (2008), which arises from their use of solidus temperatures rather than liquidus temperatures for melt compositions along a LLD, as used in this study (Fig. 10a). In natural systems zircon crystallization will occur somewhere between the liquidus and solidus temperatures depending on the melt composition and $\mathrm{Zr}$ content (Watson and Harrison, 1983). Implementing experimentally constrained $\mathrm{T}-\mathrm{SiO}_{2}$ relationships, we calculate $\Delta^{18} \mathrm{O}_{\text {melt-zrc }}$ values of $0.8 \%$ and $1.5 \%$ for hot, dry and "cool", water-saturated granodioritic melts $\left(\sim 67 \mathrm{wt} \% \mathrm{SiO}_{2}\right)$, respectively.

In order to calculate appropriate temperatures for mineral-melt fractionations, estimates of crystallization temperature can be obtained from geothermometry, including Ti-in-zircon thermometry (Watson et al., 2006; Ferry and Watson, 2007; Fu et al., 2008), or estimates through zircon saturation temperatures (Watson and Harrison, 1983; Hanchar and Watson, 2003). Water contents of granitic melts may also be determined using experimentally determined plagioclase-liquid hygrometers (Lange et al., 2009) which can then help to constrain magmatic temperatures when used in conjunction with the $\mathrm{T}-\mathrm{H}_{2} \mathrm{O}$ relationships for granitic melts (Ebadi and Johannes, 1991; Holtz and Johannes, 1994).

Once constituent mineralogy or bulk composition and magmatic temperatures are known for a magmatic rock, $\Delta^{18} \mathrm{O}_{\text {melt-zrc }}$ may be calculated in a relatively straightforward manner. The bulk rock composition may be assumed to be the melt composition and be treated as a mixture of CIPW minerals. This assumption is valid as long as the rock is not cumulative in nature nor does it contain abundant phenocrysts. For high silica rocks, the primary CIPW normative mineralogy will be albite, anorthite, orthoclase, and quartz with lesser hypersthene, corundum, or oxides. Using experimentally or empirically determined coefficients between CIPW normative minerals and zircon $\left(A_{M i n-Z r C}\right)$ to calculate mineralzircon fractionations $\left(\Delta_{\min -z r c}\right)$, bulk melt-zircon fractionation may be calculated as:

$$
\Delta_{m e l t-z r c} \approx \sum\left(A_{i-z r c} * X_{i}\right) *\left(\frac{10^{6}}{T^{2}}\right)
$$

where $X_{i}$ indicates the CIPW normative mass percent of mineral $i$ and $\mathrm{T}$ (in $\mathrm{K}$ ) indicates the temperature of zircon crystallization. Consider a water-saturated and a dry granite, both with $X_{q t z}=0.31, X_{\mathrm{Ab}}=0.32$, $X_{A n}=0.11, X_{O r}=0.19, X_{H y p}=0.07, X_{I l m}=0.006$, but with eutectic or minimum temperatures of 650 and $900^{\circ} \mathrm{C}$, respectively (see the Appendix for a spreadsheet with an example calculation). The differing crystallization temperatures of these two granites will result in markedly different $\Delta_{\text {melt-zrc }}$ values varying from $2.04 \%$ for the wet granite to $1.13 \%$ for the dry granite.

The rhyolite record corroborates such a dichotomy in temperatures based on oxygen isotope thermometry in different minerals, with hot-dry rhyolites (e.g. Yellowstone-Snake River Plain and Iceland) and "cool"-wet rhyolites (e.g. Bishop Tuff, Fish Canyon), preserving high and low temperature 
mineral-mineral fractionations, respectively (see Loewen and Bindeman, 2016 for discussion and compilation of mineral-mineral fractionations). Using zircon and calculated melt $\delta^{18} \mathrm{O}$ values calculated from various rhyolitic provinces, the empirical $\Delta_{\text {melt-zrc }}$ values generally follow the calculated model trends for hot-dry and "cool"-wet systems (Fig. 11b). For example, the relatively "cool” Bishop Tuff records $\Delta_{m e l t-z r c}$ of 1.8-2.2\%o, whereas the Timber Mountain/Oasis Valley Caldera Complex and Yellowstone Rhyolites, preserve lower $\Delta_{\text {melt }-z r c}$ of $0.9-1.7 \%$, at melt $\mathrm{SiO}_{2} \sim 75 \mathrm{wt} \%$. Notably, the naturally determined $\Delta_{\text {melt-zrc }}$ fractionations fall somewhere between that of the Lackey et al., 2008 model based on solidus temperatures for a hydrous melt and our model results calculated at liquidus temperatures for anhydrous hot systems (Fig. 11b), suggesting that $\Delta_{\text {melt-zrc }}$ values may actually preserve a continuum of temperatures between the zircon saturation and the solidus.

\section{CONCLUSIONS}

When interpreting the oxygen isotope record, it is important to consider not only how the source region or assimilated materials contribute to the $\delta^{18} \mathrm{O}$ values of igneous rocks and minerals, but also how processes such as fractional crystallization may affect the $\delta^{18} \mathrm{O}$ values of melts. We have constrained the $\delta^{18} \mathrm{O}$ trajectory of fractionally crystallizing melts through combining detailed mass balance modeling of six different liquid lines of descent and analysis of oxygen isotope compositions of minerals from two end-member fractionation sequences. Oxygen isotope trajectories of crystallizing melts will strongly depend on the specific melt fraction-temperature- $\mathrm{SiO}_{2}$ relationships and crystallizing mineralogy. This dependence allows for a distinction between the $\delta^{18} \mathrm{O}$ paths of crystallizing hydrous, calc-alkaline versus dry, tholeiitic melts. Hydrous melts undergo overall greater increases in $\delta^{18} \mathrm{O}$ compared to dry melts due to their lower temperatures, higher $\mathrm{SiO}_{2}$ contents, and greater abundance of low $\delta^{18} \mathrm{O}$ crystallizing minerals. Absolute increases in $\delta^{18} \mathrm{O}$ as a melt crystallizes over a $\mathrm{SiO}_{2}$ interval of $\sim 50$ to $70 \mathrm{wt} . \%$ may vary between $1.0-1.5 \%$. The modeled increases suggest that for hydrous arc-related basalts with initial $\delta^{18} \mathrm{O}$ of $5.7-7.0 \%$, evolved melts (i.e. granites) with $\delta^{18} \mathrm{O}$ values of 7.2-8.5\% can be produced through closed-system fractional crystallization alone. Our modeling results also demonstrate that it is critical to consider specific $\mathrm{T}-\mathrm{SiO}_{2}$ relationships for crystallizing melts when using zircon $\delta^{18} \mathrm{O}$ values to calculate bulk melt $\delta^{18} \mathrm{O}$ due to the strong dependence of zircon-melt fractionations on these two variables. Accordingly, wet, "cool" granitic melts will have larger zircon-melt fractionations than hot, "dry" granites.

\section{Acknowledgements}

This study was supported by the National Science Foundation, (EAR-1322032). We thank Thomas P. Winger and Brad Erkkila for technical assistance during ILFT oxygen isotope analyses and John Valley, Kouki Kitajima, Noriko Kita, and Jim Kern for assistance with analyses at the WiscSIMS facility. WiscSIMS is partly supported by NSF (EAR03-19230, EAR10-53466, EAR13-55590). We thank Mark Feigenson and Linda Godfrey for their assistance with $\mathrm{Sr}$ and $\mathrm{Nd}$ isotope analyses at Rutgers University. 
Kari Cooper generously provided us with supplemental details about the MELTS calculations from Cooper et al., 2004. Ilya Bindeman, Colin MacPherson, and three other anonymous reviewers provided comments that greatly improved this manuscript.

(Eiler et al., 1996)

\section{REFERENCES}

Alonso-Perez R., Muntener O. and Ulmer P. (2009) Igneous garnet and amphibole fractionation in the roots of island arcs: experimental constraints on andesitic liquids. Contributions to Mineralogy and Petrology 157, 541-558.

Anderson A. T. Jr, Clayton R. N. and Mayeda T. K. (1971) Oxygen isotope thermometry of mafic igneous rocks. The Journal of Geology 79:6, 715-729.

Appora I., Eiler J. M., Matthews A. and Stolper E. M. (2003) Experimental determination of oxygen isotope fractionations between $\mathrm{CO}_{2}$ vapor and soda-melilite melt. Geochimica et Cosmochimica Acta 67, 459-471.

Auer S., Bindeman I., Wallace P., Ponomareva V. and Portnyagin M. (2009) The origin of hydrous, high$\delta^{18} \mathrm{O}$ voluminous volcanism: diverse oxygen isotope values and high magmatic water contents within the volcanic record of Klyuchevskoy volcano, Kamchatka, Russia. Contrib Mineral Petrol 157, 209 230 .

Badarch G. and Cunningham W. D. (2002) A new terrane subdivision for Mongolia: implications for the Phanerozoic crustal growth of Central Asia. Journal of Asian Earth Sciences 21, 87-110.

Baker J. A., Macpherson C. G., Menzies M. A., Thirlwall M. F., Al-Kadasi M. and Mattey D. P. (2000) Resolving Crustal and Mantle Contributions to Continental Flood Volcanism, Yemen; Constraints from Mineral Oxygen Isotope Data. Journal of Petrology 41, 1805-1820.

Bindeman I. (2008) Oxygen Isotopes in Mantle and Crustal Magmas as Revealed by Single Crystal Analysis. Reviews in Mineralogy and Geochemistry 69, 445-478.

Blatter D. L., Sisson T. W. and Hankins W. B. (2013) Crystallization of oxidized, moderately hydrous arc basalt at mid- to lower-crustal pressures: implications for andesite genesis. Contrib Mineral Petrol 166, 861-886.

Bucholz C. E., Jagoutz O., Schmidt M. W. and Sambuu O. (2014a) Phlogopite-and clinopyroxenedominated fractional crystallization of an alkaline primitive melt: petrology and mineral chemistry of the Dariv Igneous Complex, Western Mongolia. Contrib Mineral Petrol 167, 994.

Bucholz C. E., Jagoutz O., Schmidt M. W. and Sambuu O. (2014b) Fractional crystallization of high-K arc magmas: biotite- versus amphibole-dominated fractionation series in the Dariv Igneous Complex, Western Mongolia. Contrib Mineral Petrol 168, 1072.

Bucholz C. E., Eddy M. P., Jagoutz O., Bowring S. A., Schmidt M. W. and Sambuu O. (2017)

Constraining the Timescales of Magmatic Differentiation with U-Pb Zircon Geochronology. Geology $45,11-14$.

Burg J. P. (2011) The Asia-Kohistan-India Collision: Review and Discussion. In Arc-Continent Collision Frontiers in Earth Sciences. Springer Berlin Heidelberg, Berlin, Heidelberg. pp. 279-309. 
Cameron E. N. (1980) Evolution of the Lower Critical Zone, central sector, eastern Bushveld Complex, and its chromite deposits. Economic Geology 75, 845-871.

Cameron E. N. (1978) The Lower Zone of the Eastern Bushveld Complex in the Olifants River Trough. Journal of Petrology 19, 437-462.

Cavosie A. J., Kita N. T. and Valley J. W. (2009) Primitive oxygen-isotope ratio recorded in magmatic zircon from the Mid-Atlantic Ridge. American Mineralogist 94, 926-934.

Cawthorn R. G., Meyer P. S. and Kruger F. J. (1991) Major Addition of Magma at the Pyroxenite Marker in the Western Bushveld Complex, South Africa. Journal of Petrology 32, 739-763.

Chacko T., Hu X., Mayeda T. K. and Clayton R. N. (1996) Oxygen isotope fractionations in muscovite, phlogopite, and rutile. Geochemica et Cosmoschimica Acta 60, 2595-2608.

Chazot G., Lowry D., Menzies M. and Mattey D. (1997) Oxygen isotopic composition of hydrous and anhydrous mantle peridotites. Geochimica et Cosmochimica Acta 61, 161-169.

Chiba H., Chacko T., Clayton R. N. and Goldsmith J. R. (1989) Oxygen isotope fractionations involving diopside, forsterite, magnetite, and calcite: Application to geothermometry. Geochimica et Cosmochimica Acta 53, 2985-2995.

Clayton R. N., O'Neil J. R. and Mayeda T. K. (1972) Oxygen isotope exchange between quartz and water. Journal of Geophysical Research: Solid Earth (1978-2012) 77, 3057-3067.

Coleman, D.S., Frost, T.P. and Glazner, A.F., 1992. Evidence from the Lamarck Granodiorite for rapid Late Cretaceous crust formation in California. Science, 258:5090, 1924-1927.

Coleman, D.S. and Glazner, A.F., 1997. The Sierra Crest magmatic event: Rapid formation of juvenile crust during the Late Cretaceous in California. International Geology Review, 39:9, 768-787.

Day J. M. D., Macpherson C. G., Lowry D. and Pearson D. G. (2012) Oxygen isotope heterogeneity of the mantle beneath the Canary Islands: a discussion of the paper of Gurenko et al. Contrib Mineral Petrol 164, 177-183.

DePaolo D. J. and Wasserburg G. J. (1976) Inferences About Magma Sources and Mantle Structure from Variations of ${ }^{143} \mathrm{Nd} /{ }^{144} \mathrm{Nd}$. Geophys. Res. Lett. 3, 743-746.

Dijkstra A. H., Brouwer F. M., Cunningham W. D., Buchan C., Badarch G. and Mason P. R. D. (2006) Late Neoproterozoic proto-arc ocean crust in the Dariv Range, Western Mongolia: a suprasubduction zone end-member ophiolite. Journal of the Geological Society 163, 363-373.

Dodson M. H. (1973) Closure temperature in cooling geochronological and petrological systems. Contrib Mineral Petrol 40, 259-274.

Dorendorf, F., Wiechert, U. and Wörner, G., 2000. Hydrated sub-arc mantle: a source for the Kluchevskoy volcano, Kamchatka/Russia. Earth and Planetary Science Letters, 175:1, 69-86.

Ebadi A. and Johannes W. (1991) Beginning of melting and composition of first melts in the system QzAb-Or- $\mathrm{H}_{2} \mathrm{O}-\mathrm{CO}_{2}$. Contrib Mineral Petrol 106, 286-295.

Eiler J. M. (2001) Oxygen Isotope Variations of Basaltic Lavas and Upper Mantle Rocks. Reviews in Mineralogy and Geochemistry 43, 319-364. 
Eiler J. M., Baumgartner L. P. and Valley J. W. (1992) Intercrystalline stable isotope diffusion: a fast grain boundary model. Contrib Mineral Petrol 112, 543-557.

Eiler J. M., Crawford A., Elliott T., Farley K. A., Valley J. W. and Stolper E. M. (2000) Oxygen Isotope Geochemistry of Oceanic-Arc Lavas. Journal of Petrology 41, 229-256.

Eiler J. M., Carr M. J., Reagan M., and Stolper, E M. (2005) Oxygen isotope constraints on the sources of Central American arc lavas. Geochemistry, Geophysics, Geosystems 6, Q07007.

Eiler J. M., Valley J. W. and Baumgartner L. P. (1993) A new look at stable isotope thermometry. Geochimica et Cosmochimica Acta 57, 2571-2583.

Eiler J. M., Valley J. W. and Stolper E. M. (1996) Oxygen isotope ratios in olivine from the Hawaii Scientific Drilling Project. Journal of Geophysical Research: Solid Earth (1978-2012) 101, 1180711813.

Esperança S. and Holloway J. R. (1987) On the origin of some mica-lamprophyres: experimental evidence from a mafic minette. Contrib Mineral Petrol 95, 207-216.

Ferry J. M. and Watson E. B. (2007) New thermodynamic models and revised calibrations for the Ti-inzircon and Zr-in-rutile thermometers. Contrib Mineral Petrol 154, 429-437.

Fortier S. M. and Giletti B. J. (1991) Volume self-diffusion of oxygen in biotite, muscovite, and phlogopite micas. Geochimica et Cosmochimica Acta 55, 1319-1330.

Fortier S. M. and Lüttge A. (1995) An experimental calibration of the temperature dependence of oxygen isotope fractionation between apatite and calcite at high temperatures $\left(350-800^{\circ} \mathrm{C}\right)$. Chemical Geology 125, 281-290.

Fourie D. S. and Harris C. (2011) O-isotope Study of the Bushveld Complex Granites and Granophyres: Constraints on Source Composition, and Assimilation. Journal of Petrology 52, 2221-2242.

Fu B., Page F. Z., Cavosie A. J., Fournelle J., Kita N. T., Lackey J. S., Wilde S. A. and Valley J. W. (2008) Ti-in-zircon thermometry: applications and limitations. Contrib Mineral Petrol 156, 197-215.

Giletti B. J. (1986) Diffusion effects on oxygen isotope temperatures of slowly cooled igneous and metamorphic rocks. Earth and Planetary Science Letters 77, 218-228.

Giletti B. J. and Yund R. A. (1984) Oxygen diffusion in quartz. Journal of Geophysical Research: Solid Earth (1978-2012) 89, 4039-4046.

Giletti B. J., Semet M. P. and Yund R. A. (1978) Studies in diffusion-III. Oxygen in feldspars: an ion microprobe determination. Geochimica et Cosmochimica Acta 42, 45-57.

Gregory R. T., Criss R. E. and Taylor H. P. Jr. (1989) Oxygen Isotope Exchange Kinetics of Mineral Pairs in Closed and Open Systems: Applications to Problems of Hydrothermal Alteration of Igneous Rocks and Precambrian Iron Formations. Chemical Geology 75, 1-42.

Grimes C. B., Ushikubo T., John B. E. and Valley J. W. (2011) Uniformly mantle-like $\delta 180$ in zircons from oceanic plagiogranites and gabbros. Contrib Mineral Petrol 161, 13-33.

Grove T. L., Kinzler R. J. and Bryan W. B. (1992) Fractionation of Mid-Ocean Ridge Basalt (MORB). In pp. 281-310.

Hanchar J. M. and Watson E. B. (2003) Zircon saturation thermometry. Reviews in Mineralogy and 
Geochemistry 53, 89-112.

Harmon R. S. and Hoefs J. (1995) Oxygen isotope heterogeneity of the mantle deduced from global 180 systematics of basalts from different geotectonic settings. Contrib Mineral Petrol 120, 95-114.

Harris, C., Faure, K., Diamond, R.E. and Scheepers, R., 1997. Oxygen and hydrogen isotope geochemistry of S-and I-type granitoids: the Cape Granite suite, South Africa. Chemical Geology, 143:1-2, 95-114.

Harris C. and Chaumba J. B. (2001) Crustal Contamination and Fluid-Rock Interaction during the Formation of the Platreef, Northern Limb of the Bushveld Complex, South Africa. Journal of Petrology 42, 1321-1347.

Harris C., Pronost J. and Ashwal L. D. (2005) Oxygen and hydrogen isotope stratigraphy of the Rustenburg Layered Suite, Bushveld Complex: constraints on crustal contamination. Journal of Petrology 46, 579-601.

Harris C., Smith H. S. and le Roex A. P. (2000) Oxygen isotope composition of phenocrysts from Tristan da Cunha and Gough Island lavas: variation with fractional crystallization and evidence for assimilation. Contrib Mineral Petrol 138, 164-175.

Holtz F. and Johannes W. (1994) Maximum and minimum water contents of granitic melts: implications for chemical and physical properties of ascending magmas. Lithos 32, 149-159.

Ingrin J., Pacaud L. and Jaoul O. (2001) Anisotropy of oxygen diffusion in diopside. Earth and Planetary Science Letters 192, 347-361.

Ionov D. A., Harmon R. S., France-Lanord C., Greenwood P. B. and Ashchepkov I. V. (1994) Oxygen isotope composition of garnet and spinel peridotites in the continental mantle: Evidence from the Vitim xenolith suite, southern Siberia. Geochimica et Cosmochimica Acta 58, 1463-1470.

Ito E., White W. M. and Göpel C. (1987) The O, Sr, Nd and Pb isotope geochemistry of MORB. Chemical Geology 62, 157-176.

Jagoutz O. and Schmidt M. W. (2013) The composition of the foundered complement to the continental crust and a re-evaluation of fluxes in arcs. Earth and Planetary Science Letters 371-372, 177-190.

Jagoutz O. E. (2010) Construction of the granitoid crust of an island arc. Part II: a quantitative petrogenetic model. Contrib Mineral Petrol 160, 359-381.

James D. E. (1981) The combined use of oxygen and radiogenic isotopes as indicators of crustal contamination. Annu. Rev. Earth Planet. Sci 9, 311-344.

Johnson E. R., Wallace P. J., Delgado Granados H., Manea V. C., Kent A. J. R., Bindeman I. N. and Donegan C. S. (2009) Subduction-related Volatile Recycling and Magma Generation beneath Central Mexico: Insights from Melt Inclusions, Oxygen Isotopes and Geodynamic Models. Journal of Petrology 50, 1729-1764.

Juster T. C., Grove T. L. and Perfit M. R. (1989) Experimental constraints on the generation of FeTi basalts, andesites, and rhyodacites at the Galapagos Spreading Center, $85 \mathrm{~W}$ and $95 \mathrm{~W}$. Journal of Geophysical Research: Solid Earth (1978-2012) 94, 9251-9274 .

Kalamarides R. I. (1984) Kiglapait Geochemistry VI: Oxygen Isotopes. Geochimica et Cosmochimica Acta 48, 1827-1836. 
Khain E. (2003) The Palaeo-Asian ocean in the Neoproterozoic and early Palaeozoic: new geochronologic data and palaeotectonic reconstructions. Precambrian Research 122, 329-358.

Kruger F. J., Cawthorn R. G. and Walsh K. L. (1987) Strontium isotopic evidence against magma addition in the Upper Zone of the Bushveld Complex. Earth and Planetary Science Letters 84, 51-58.

Lackey, J.S., Valley, J.W. and Hinke, H.J., 2006. Deciphering the source and contamination history of peraluminous magmas using $\delta^{18} \mathrm{O}$ of accessory minerals: examples from garnet-bearing plutons of the Sierra Nevada batholith. Contributions to Mineralogy and Petrology, 151:1, 20-44.

Lackey J. S., Valley J. W., Chen J. H. and Stockli D. F. (2008) Dynamic Magma Systems, Crustal Recycling, and Alteration in the Central Sierra Nevada Batholith: the Oxygen Isotope Record. Journal of Petrology 49, 1397-1426.

Lange R. A., Frey H. M. and Hector J. (2009) A thermodynamic model for the plagioclase-liquid hygrometer/thermometer. American Mineralogist 94, 494-506.

Liang Y., Sun C., Ashwal L. D. and VanTongeren J. A. (2013) Spatial variations in temperature across the Bushveld layered intrusion revealed by REE-in-plagioclase-pyroxene thermometers with implications for magma chamber processes. AGU Fall Meeting Abstracts. San Francisco, CA.

Loewen, M.W. and Bindeman, I.N., 2015. Oxygen isotope and trace element evidence for three-stage petrogenesis of the youngest episode (260-79 ka) of Yellowstone rhyolitic volcanism. Contributions to Mineralogy and Petrology, 170:4, 39.

Loewen, M.W. and Bindeman, I.N., 2016. Oxygen isotope thermometry reveals high magmatic temperatures and short residence times in Yellowstone and other hot-dry rhyolites compared to coldwet systems. American Mineralogist, 101:5, pp.1222-1227.

Lugmair, G.W and Marti, K. (1978). Lunar initial ${ }^{143} \mathrm{Nd} /{ }^{144} \mathrm{Nd}$ : differential evolution of the lunar crust and mantle. Earth and Planetary Science Letters 39, 349-357.

Macpherson C. G. and Mattey D. P. (1998) Oxygen isotope variations in Lau Basin lavas. Chemical Geology 144, 177-194.

Magartiz M., Whitford D. J. and James D. E. (1978) Oxygen Isotopes and the Origin of High- ${ }^{87} \mathrm{Sr} /{ }^{86} \mathrm{Sr}$ Andesites. Earth and Planetary Science Letters, 220-230.

Martin, E., Bindeman, I. and Grove, T.L., 2011. The origin of high-Mg magmas in Mt Shasta and Medicine Lake volcanoes, Cascade Arc (California): higher and lower than mantle oxygen isotope signatures attributed to current and past subduction. Contributions to Mineralogy and Petrology, 162:5, 945-960.

Matsuhisa Y. (1979) Oxygen isotopic compositions of volcanic rocks from the East Japan island arcs and their bearing on petrogenesis. Journal of Volcanology and Geothermal Research 5, 271-296.

Matsuhisa Y., Matsubaya O. and Sakai H. (1973) Oxygen isotope variations in magmatic differentiation processes of the volcanic rocks in Japan. Contrib Mineral Petrol 39, 277-288.

Mattey D., Lowry D. and Macpherson C. (1994) Oxygen isotope composition of mantle peridotite. Earth and Planetary Science Letters 128, 231-241.

Matthews A., Palin J. M., Epstein S. and Stolper E. M. (1994) Experimental study of ${ }^{18} \mathrm{O} /{ }^{16} \mathrm{O}$ partitioning between crystalline albite, albitic glass and $\mathrm{CO}_{2}$ gas. Geochemica et Cosmoschimica Acta, 58, 5255- 
5266.

Melekhova E., Annen C. and Blundy J. (2013) Compositional gaps in igneous rock suites controlled by magma system heat and water content. Nature Geosci 6, 1-5.

Melekhova E., Blundy J., Robertson R. and Humphreys M. C. S. (2015) Experimental Evidence for Polybaric Differentiation of Primitive Arc Basalt beneath St. Vincent, Lesser Antilles. Journal of Petrology 56, 161-192.

Médard E. and Grove T. L. (2007) The effect of $\mathrm{H}_{2} \mathrm{O}$ on the olivine liquidus of basaltic melts: experiments and thermodynamic models. Contrib Mineral Petrol 155, 417-432.

Miyashiro A. (1974) Volcanic rock series in island arcs and active continental margins. American Journal of Science 274, 321-355.

Molyneux T. G. (1974) A geological investigation of the Bushveld Complex in Sekhukhuneland and part of the Steelpoort valley, Transactions of the Geological Society of South Africa 77, 329-338.

Muehlenbachs K. and Byerly G. (1982) ${ }^{18} \mathrm{O}$-Enrichment of silicic magmas caused by crystal fractionation at the Galapagos Spreading Center. Contrib Mineral Petrol 79, 76-79.

Müntener O., Kelemen P. B. and Grove T. L. (2001) The role of H2O during crystallization of primitive arc magmas under uppermost mantle conditions and genesis of igneous pyroxenites: an experimental study. Contrib Mineral Petrol 141, 643-658.

Mysen B. O., Virgo D., Harrison W. J. and Scarfe C. M. (1980) Solubility mechanisms of $\mathrm{H}_{2} \mathrm{O}$ in silicate melts at high pressures and temperatures: a Raman spectroscopic study. American Mineralogist 65, 900-914.

Nandedkar R. H., Ulmer P. and Müntener O. (2014) Fractional crystallization of primitive, hydrous arc magmas: an experimental study at $0.7 \mathrm{GPa}$. Contrib Mineral Petrol 167, 1015.

Nicholls I. A. and Ringwood A. E. (1973) Effect of water on olivine stability in tholeiites and the production of silica-saturated magmas in the island-arc environment. The Journal of Geology $\mathbf{8 1}$, 285-300.

Nitsan U. (1974) Stability field of olivine with respect to oxidation and reduction. Journal of Geophysical Research: Solid Earth (1978-2012) 79, 706-711.

O'Neil, J.R., Shaw, S.E. and Flood, R.H., 1977. Oxygen and hydrogen isotope compositions as indicators of granite genesis in the New England Batholith, Australia. Contributions to Mineralogy and Petrology, 62:3, 313-328.

Page F. Z., Ushikubo T., Kita N. T. and Riciputi L. R. (2007) High-precision oxygen isotope analysis of picogram samples reveals $2 \mu \mathrm{m}$ gradients and slow diffusion in zircon. American Mineralogist 92, 1772-1775.

Palin J. M., Epstein S. and Stolper E. M. (1996) Oxygen isotope partitioning between rhyolitic glass/melt and $\mathrm{CO}_{2}$ : An experimental study at $550-950^{\circ} \mathrm{C}$ and 1 bar. Geochimica et Cosmochimica Acta $\mathbf{6 0}$, 1963-1973.

Portnyagin, M., Bindeman, I., Hoernle, K., \& Hauff, F. (2007). Geochemistry of primitive lavas of the Central Kamchatka Depression: magma generation at the edge of the Pacific Plate. Volcanism and subduction: The Kamchatka region, 199-239. 
Reid D. L., Cawthorn R. G., Kruger F. J. and Tredoux M. (1993) Isotope and trace-element patterns below the Merensky Reef, Bushveld Complex, South Africa: evidence for fluids? Chemical Geology 106, 171-186.

Righter K. and Carmichael I. S. E. (1996) Phase equilibria of phlogopite lamprophyres from western Mexico: biotite-liquid equilibria and P-T estimates for biotite-bearing igneous rocks. Contrib Mineral Petrol 123, 1-21.

Roeder P. L. and Emslie R. F. (1970) Olivine-liquid equilibrium. Contrib Mineral Petrol 29, 275-289.

Ruscitto D. M., Wallace P. J., Johnson E. R., Kent A. J. R. and Bindeman I. N. (2010) Volatile contents of mafic magmas from cinder cones in the Central Oregon High Cascades: Implications for magma formation and mantle conditions in a hot arc. Earth and Planetary Science Letters 298, 153-161.

Ruscitto D. M., Wallace P. J. and Kent A. J. R. (2011) Revisiting the compositions and volatile contents of olivine-hosted melt inclusions from the Mount Shasta region: implications for the formation of high-Mg andesites. Contrib Mineral Petrol 162, 109-132.

Schiffries C. M. and Rye D. M. (1989) Stable isotopic systematics of the Bushveld Complex; I, Constraints of magmatic processes in layered intrusions, American Journal of Science 289, 841-873.

Sharp Z. D. (1990) A laser-based microanalytical method for the in situ determination of oxygen isotope ratios of silicates and oxides. Geochimica et Cosmochimica Acta 54, 1353-1357.

Sharpe M. R. (1985) Strontium isotope evidence for preserved density stratification in the main zone of the Bushveld Complex, South Africa. Nature 316, 119-126.

Sisson T. W. and Grove T. L. (1993) Experimental investigations of the role of $\mathrm{H} 2 \mathrm{O}$ in calc-alkaline differentiation and subduction zone magmatism. Contrib Mineral Petrol 113, 143-166.

Sisson T. W., Ratajeski K., Hankins W. B. and Glazner A. F. (2005) Voluminous granitic magmas from common basaltic sources. Contrib Mineral Petrol 148, 635-661.

Steiger, R. H. \& Jäger, E. (1977) Subcommission on geochronology: convention on the use of decay constants in geo- and cosmochronology. Earth and Planetary Science Letters 36, 359-362.

Stolper E. (1980) A phase diagram for mid-ocean ridge basalts: Preliminary results and implications for petrogenesis. Contrib Mineral Petrol 74, 13-27.

Stolper E. and Epstein S. (1991) An experimental study of oxygen isotope partitioning between silica glass and $\mathrm{CO}_{2}$ vapor, Stable Isotope Geochemistry 35-51.

Straub, S.M., Gómez-Tuena, A., Bindeman, I.N., Bolge, L.L., Brandl, P.A., Espinasa-Perena, R., Solari, L., Stuart, F.M., Vannucchi, P. and Zellmer, G.F., 2015. Crustal recycling by subduction erosion in the central Mexican Volcanic Belt. Geochimica et Cosmochimica Acta, 166, $29-52$.

Sun C., Liang Y., Ashwal L. and VanTongeren J. (2013) Temperature Variations Along Stratigraphic Height Across the Bushveld Complex with Implications for Magma Chamber Processes in Layered Intrusions. In 2013 GSA Annual Meeting Denver, CO.

Taylor H. P. and Epstein S. (1963) $\mathrm{O}^{18} / \mathrm{O}^{16}$ ratios in rocks and coexisting minerals of the Skaergaard intrusion, east Greenland. Journal of Petrology 4, 51-74.

Taylor H. P. and Forester R. W. (1979) An oxygen and hydrogen isotope study of the Skaergaard 
intrusion and its country rocks: a description of a 55 my old fossil hydrothermal system. Journal of Petrology 20, 355-419.

Taylor H. P. Jr (1968) The oxygen isotope geochemistry of igneous rocks. Contrib Mineral Petrol 19, 171.

Taylor H. P. Jr. and Sheppard S. M. F. (1986) Igneous Rocks: 1. Processes of Isotopic Fractionation and Isotope Systematics. In Stable Isotopes in High Temperature Geological Processes (eds. J. W. Valley, H. P. J. Taylor, and J. R. O'Neil). Mineralogical Society of America. pp. 227-271.

Tegner C., Cawthorn R. G. and Kruger F. J. (2006) Cyclicity in the Main and Upper Zones of the Bushveld Complex, South Africa: Crystallization from a Zoned Magma Sheet. Journal of Petrology 47, 2257-2279.

Tollan P. M. E., Bindeman I. and Blundy J. D. (2012) Cumulate xenoliths from St. Vincent, Lesser Antilles Island Arc: a window into upper crustal differentiation of mantle-derived basalts. Contrib Mineral Petrol 163, 189-208.

Toplis M. J. and Carroll M. R. (1995) An Experimental Study of the Influence of Oxygen Fugacity on FeTi Oxide Stability, Phase Relations, and Mineral-Melt Equilibria in Ferro-Basaltic Systems. Journal of Petrology 36, 1137-1170.

Valley J. W. (2003) Oxygen isotopes in zircon. Reviews in Mineralogy and Geochemistry 53, 343-385.

Valley J. W. (2001) Stable Isotope Thermometry at High Temperatures. Reviews in Mineralogy and Geochemistry 43, 365-413.

Valley J. W., Kinny P. D. and Schulze D. J. (1998) Zircon megacrysts from kimberlite: oxygen isotope variability among mantle melts. Contributions to Mineralogy and Petrology 133, 1-11.

Valley J. W., Kitchen N., Kohn M. J. and Niendorf C. R. (1995) UWG-2, a garnet standard for oxygen isotope ratios: strategies for high precision and accuracy with laser heating. Geochemica et Cosmoschimica Acta 59, 5223-5231.

Valley J. W., Peck W. H., King E. M. and Wilde S. A. (2002) A cool early Earth. Geology 30, 351-354.

VanTongeren J. A. and Mathez E. A. (2013) Incoming Magma Composition and Style of Recharge below the Pyroxenite Marker, Eastern Bushveld Complex, South Africa. Journal of Petrology 54, 15851605.

VanTongeren J. A. and Mathez E. A. (2012) Large-scale liquid immiscibility at the top of the Bushveld Complex, South Africa. Geology 40, 491-494.

VanTongeren J. A., Mathez E. A. and Kelemen P. B. (2010) A Felsic End to Bushveld Differentiation. Journal of Petrology 51, 1891-1912.

Villiger S., Ulmer P., Müntener O. and Thompson A. B. (2004) The Liquid Line of Descent of Anhydrous, Mantle-Derived, Tholeiitic Liquids by Fractional and Equilibrium Crystallization - an Experimental Study at 1.0 GPa. Journal of Petrology 45, 2369-2388.

von Gruenewaldt G. (1973) The main and upper zones of the Bushveld Complex in the Roossenekal area, eastern Transvaal, Transactions of the Geological Society of South Africa 76, 207-227.

Walker D., Shibata T. and DeLong S. E. (1979) Abyssal Tholeiites From the Oceanographer Fracture Zone. II. Phase Equilibra and Mixing. Contributions to Mineralogy and Petrology 70, 111-125. 
Wang X.-L., Coble M. A., Valley J. W., Shu X.-J., Kitajima K., Spicuzza M. J. and Sun T. (2014) Influence of radiation damage on Late Jurassic zircon from southern China: Evidence from in situ measurements of oxygen isotopes, laser Raman, $\mathrm{U}-\mathrm{Pb}$ ages, and trace elements. Chemical Geology 389, 122-136.

Watson E. B. and Cherniak D. J. (1997) Oxygen diffusion in zircon. Earth and Planetary Science Letters 148, 527-544.

Watson E. B. and Harrison T. M. (1983) Zircon saturation revisited: temperature and composition effects in a variety of crustal magma types. Earth and Planetary Science Letters 64, 295-304.

Watson E. B., Wark D. A. and Thomas J. B. (2006) Crystallization thermometers for zircon and rutile. Contrib Mineral Petrol 151, 413-433.

Whitaker M. L., Nekvasil H., Lindsley D. H. and McCurry M. (2008) Can crystallization of olivine tholeiite give rise to potassic rhyolites? - an experimental investigation. Bull Volcanol 70, 417-434.

Woodhead J. D., Harmon R. S. and Fraser D. G. (1987) O, S, Sr, and Pb isotope variations in volcanic rocks from the Northern Mariana Islands: implications for crustal recycling in intra-oceanic arcs. Earth and Planetary Science Letters 83, 39-52.

Zheng Y.-F. (1991) Calculation of oxygen isotope fractionation in metal oxides. Geochimica et Cosmochimica Acta 55, 2299-2307.

Zheng Y. F. (1993a) Calculation of oxygen isotope fractionation in anhydrous silicate minerals. Geochimica et Cosmochimica Acta 57, 1079-1091.

Zheng Y. F. (1993b) Calculation of oxygen isotope fractionation in hydroxyl-bearing silicates. Earth and Planetary Science Letters 120, 247-263. 


\begin{tabular}{|c|c|c|c|c|c|c|c|c|c|c|c|c|c|c|c|c|c|c|c|c|c|c|}
\hline Reference & Study Type & $\begin{array}{c}\text { Locality or Source of } \\
\text { Starting Material } \\
\end{array}$ & Parental Melt & $\begin{array}{c}\begin{array}{c}\text { Initial } \mathbf{H}_{2} \mathbf{O} \\
(\text { wt. \%) }\end{array} \\
\end{array}$ & $\begin{array}{c}\text { Temperature } \\
\text { Range }\left({ }^{\circ} \mathrm{C}\right) \\
\end{array}$ & $\begin{array}{c}\text { Pressure } \\
(\text { GPa })\end{array}$ & $\begin{array}{l}\text { Crystallizing } \\
\text { Mineralogy* } \\
\end{array}$ & $\begin{array}{c}\text { Melt } \\
\text { Fraction } \\
\text { Range } \\
\end{array}$ & $\mathrm{SiO}_{2}$ & $\mathrm{TiO}_{2}$ & $\mathrm{Al}_{2} \mathrm{O}_{3}$ & $\mathrm{Cr}_{2} \mathrm{O}_{3}$ & $\mathrm{Fe}_{2} \mathrm{O}_{3}$ & $\mathrm{FeO}$ & $\mathrm{MnO}$ & MgO & $\mathrm{CaO}$ & $\mathrm{Na}_{2} \mathrm{O}$ & $\mathrm{K}_{2} \mathrm{O}$ & $\mathbf{P}_{2} \mathrm{O}_{5}$ & TOTAL & Mg\# \\
\hline $\begin{array}{l}\text { Villiger et al., } \\
\quad \text { (2004) }\end{array}$ & Experimental & $\begin{array}{l}\text { Partial Melting } \\
\text { Experiments of Hirose } \\
\text { \& Kushiro (1993) }\end{array}$ & $\begin{array}{c}\text { Synthetic Primitive } \\
\text { Tholeititic Basalt } \\
\text { (HK\#19) }\end{array}$ & 0 & $1330-1060$ & 1.0 & $\begin{array}{l}\text { Ol, Opx, Cpx, Sp, } \\
\text { Ilm, Plag, Qtz }\end{array}$ & $1.0-0.06$ & 49.43 & 0.68 & 15.03 & 0.35 & 0.00 & 6.68 & 0.16 & 12.99 & 12.68 & 1.94 & 0.07 & 0.00 & 100.00 & 77.6 \\
\hline $\begin{array}{l}\text { Whitaker et al., } \\
\quad(2008)\end{array}$ & Experimental & Snake River Plain, USA & $\begin{array}{l}\text { Primitve Olivine } \\
\text { Tholeiite (1260) }\end{array}$ & 0.4 & $1280-1160$ & 0.4 & $\begin{array}{l}\text { Ol, Cpx, Plag, } \\
\text { Ilm, Ap, Pig }\end{array}$ & $1.0-0.02$ & 48.13 & 1.45 & 15.22 & 0.00 & 1.78 & 9.06 & 0.16 & 10.59 & 10.70 & 2.21 & 0.43 & 0.26 & 100.00 & 63.9 \\
\hline $\begin{array}{l}\text { Nandekhar et al., } \\
\quad(2014)\end{array}$ & Experimental & $\begin{array}{l}\text { Adamello Batholith, } \\
\text { Italy }\end{array}$ & $\begin{array}{c}\text { Synthetic near- } \\
\text { primary olivine } \\
\text { tholeite (RDC156) }\end{array}$ & 3.6 & $1170-700$ & 0.7 & $\begin{array}{l}\text { Ol, Cpx, Opx, } \\
\text { Oxides (Mgt, Usp, } \\
\text { Sp), Amph, Plag, } \\
\text { Ap, Bt, Qtz }\end{array}$ & $1-0.14$ & 50.27 & 0.73 & 15.05 & 0.00 & 0.00 & 8.77 & 0.19 & 10.16 & 12.13 & 1.95 & 0.64 & 0.11 & 100.00 & 67.4 \\
\hline Jagoutz (2010) & Field Based & Kohistan, Pakistan & $\begin{array}{l}\text { Primitive Calc- } \\
\text { alkaline Basalt }\end{array}$ & $2-3$ & $1140-670$ & $0.8-1.5$ & $\begin{array}{c}\text { Ol, Cpx, Opx, Grt, } \\
\text { Amph, Mgt, Plag, } \\
\text { Qtz }\end{array}$ & $1.0-0.1$ & 50.72 & 0.80 & 15.67 & 0.06 & 0.00 & 8.60 & 0.17 & 10.87 & 9.88 & 2.43 & 0.61 & 0.19 & 100.00 & 69.3 \\
\hline $\begin{array}{l}\text { VanTongeren et al, } \\
\text { (2010) }\end{array}$ & Field Based & $\begin{array}{l}\text { Bushveld UUMZ, } \\
\text { South Africa }\end{array}$ & Tholeiitic Basalt & 1 & $1200-940$ & 0.2 & $\begin{array}{l}\text { Opx, Pig, Cpx, } \\
\text { Plag, Mgt, Ap, Bt, } \\
\text { Alkali Fsp }\end{array}$ & $1.0-0.18$ & 50.83 & 1.54 & 15.87 & 0.00 & 1.98 & 12.08 & 0.19 & 5.35 & 8.22 & 2.51 & 1.08 & 0.34 & 100.00 & 40.8 \\
\hline $\begin{array}{l}\text { Bucholz et al., } \\
\quad(2014 b)\end{array}$ & Field Based & $\begin{array}{l}\text { Dariv Igneous } \\
\text { Complex, Western } \\
\text { Mongolia }\end{array}$ & $\begin{array}{l}\text { Primitive High-K } \\
\text { Basalt }\end{array}$ & 2.5 & $1150-700$ & $0.3-0.5$ & $\begin{array}{l}\text { Ol, Cpx, Phl, Mgt, } \\
\text { Ap, Alkali Fsp, } \\
\text { Plag, Amph, Qtz }\end{array}$ & $1.0-0.07$ & 52.00 & 1.10 & 12.90 & 0.08 & 0.00 & 7.85 & 0.16 & 11.26 & 8.70 & 2.50 & 2.96 & 0.49 & 100.00 & 71.9 \\
\hline
\end{tabular}

*Mineral Abbreviations: Ol: olivine, Cpx: clinopyroxene, Opx: orthopyroxene, Pig: pigeonite, Ap: apatite, Plag: plagioclase, Ilm: ilmenite, Mgt: magnetite, Sp: spinel, Alkali Fsp: alkali feldspar, Bt: biotite, Amph: Amphibole, Qtz: Quartz. 
Table 2: Oxygen isotope composition of minerals from the Bushveld Igneous Complex, South Africa

\begin{tabular}{|c|c|c|c|c|c|c|c|c|c|c|c|c|c|c|}
\hline Sample & Rock Type & $\begin{array}{l}\text { Height above } \\
\text { PM (m) }\end{array}$ & $\begin{array}{l}\mathrm{SiO}_{2} \\
\text { (WR) }\end{array}$ & $\begin{array}{l}\mathrm{Mg \#} \\
\text { (WR) }\end{array}$ & Mineral (n) & $\begin{array}{c}\text { Olivine } \\
\text { Mg\# }\end{array}$ & Cpx Mg\# & Opx Mg\# & $\operatorname{Plg} X_{A n}$ & $\delta^{18} \mathrm{O}_{\mathrm{OI}}$ & $\delta^{18} \mathrm{O}_{\mathrm{Cpx}}$ & $\delta^{18} \mathrm{O}_{\mathrm{Opx}}$ & $\delta^{18} \mathrm{O}_{\mathrm{Plg}}$ & $\delta^{18} \mathrm{O}_{\mathrm{Mgt}}$ \\
\hline$\overline{\mathrm{B} 06-062}$ & Gabbronorite & 125 & $\overline{52.32}$ & 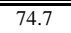 & Cpx(4), Opx(3), $\mathrm{Plg}(2)$ & & 80.30 & 73.73 & 72.71 & & $\begin{array}{l}5.76(0.12) \\
\end{array}$ & $\begin{array}{ll}6.17(0.09) \\
\end{array}$ & $\begin{array}{l}6.77(0.01) \\
\end{array}$ & \\
\hline B06-067 & Gabbronorite & 575 & 51.58 & 67.1 & $\mathrm{Cpx}(2), \mathrm{Opx}(2), \mathrm{Plg}(2)$ & & 73.38 & 63.85 & 62.66 & & $5.76(0.02)$ & $6.08(0.01)$ & $6.65(0.06)$ & \\
\hline B07-057 & Magnetite Gabbro & 922 & 46.81 & 36.4 & $\mathrm{Cpx}(2), \mathrm{Opx}(2), \mathrm{Plg}(2)$ & & 62.00 & & 59.5 & & $5.96(0.03)$ & $6.17(0.03)$ & $7.15(0.11)$ & $1.74(0.37)$ \\
\hline B06-024 & Troctolite & 1315 & 42.77 & 41.8 & $\mathrm{Ol}(2), \operatorname{Plg}(2)$ & 46.05 & 65.00 & 57.49 & 54.4 & $5.42(0.04)$ & & & $7.01(0.00)$ & \\
\hline B06-029 & Olivine-Magnetite Gabbro & 1883 & 39.14 & 29.2 & $\mathrm{Ol}(1), \mathrm{Plg}(2)$ & 34.59 & 58.11 & & 45.3 & $5.37(0.03)$ & & & 6.92 & \\
\hline B07-027 & Olivine-Magnetite Gabbro & 2032 & 40.69 & 27.1 & $\operatorname{Plg}(2)$ & 33.92 & 59.92 & & 47.1 & & & & $6.88(0.01)$ & \\
\hline B06-055 & Olivine-Magnetite Gabbro & 2155 & & & Plg(2) & 23.66 & & & 49.1 & & & & $6.81(0.03)$ & \\
\hline B07-038 & Olivine-Magnetite Gabbro & 2330 & 49.51 & 9.2 & $\mathrm{Ol}(1), \mathrm{Plg}(2)$ & 10.25 & 38.86 & 24.91 & 46.3 & 5.10 & & & $6.85(0.09)$ & $4.69(0.33)$ \\
\hline B07-041 & Olivine-Magnetite Gabbro & 2390 & 47.00 & 14.2 & $P \lg (2)$ & 8.8 & 29.43 & & 40.7 & & & & $6.85(0.03)$ & \\
\hline
\end{tabular}

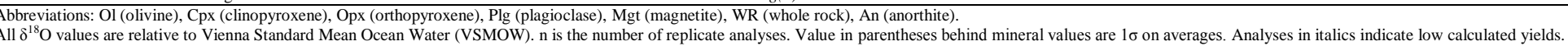

Whole rock and mile relative to Vienna Standard Mean Ocean Water (VSMOW

*We report magnetite data for the two samples we analyzed, however urge readers to treat it with caution as yields were low and values were not reproducible. 
Table 3: Oxygen isotope composition of minerals from the Dariv Igneous Complex

\begin{tabular}{|c|c|c|c|c|c|c|c|c|c|c|c|c|}
\hline Sample & Rock Type & $\begin{array}{l}\mathrm{SiO}_{2} \\
\text { (WR) } \\
\end{array}$ & $\begin{array}{l}\text { Mg\# } \\
\text { (WR) } \\
\end{array}$ & Mineral $(\mathrm{n})$ & $\begin{array}{c}\text { Olivine } \\
\mathrm{Mg} \# \\
\end{array}$ & $\begin{array}{l}\mathrm{Cpx} \\
\mathrm{Mg \#} \\
\end{array}$ & $\delta^{18} \mathrm{O}_{\mathrm{Ol}}$ & $\delta^{18} \mathrm{O}_{\mathrm{Cpx}}$ & $\delta^{18} \mathrm{O}_{\mathrm{Bt}}$ & $\delta^{18} \mathrm{O}_{\mathrm{Qtz}}$ & $\delta^{18} \mathrm{O}_{\mathrm{Zrc}}$ & $\delta^{18} \mathrm{O}_{\mathrm{WR}}$ \\
\hline MO-11-2 & Serpentinite & 44.14 & 91.5 & $\mathrm{WR}(2)$ & & & & & & & & $3.87(0.04)$ \\
\hline MO-12-21 & Wehrlite & 52.67 & 90.7 & $\mathrm{Ol}(2), \mathrm{Cpx}(2)$ & 87.0 & 91.4 & $6.51(0.01)$ & $6.73(0.01)$ & & & & \\
\hline MO-10-396 & $\begin{array}{c}\text { Phlogopite } \\
\text { Wehrlite }\end{array}$ & 51.86 & 89.1 & $\mathrm{Ol}(3), \mathrm{Cpx}(3), \mathrm{Bt}(2)$ & 86.3 & 90.6 & $6.73(0.02)$ & $6.67(0.08)$ & $7.06(0.05)$ & & & \\
\hline MO-10-394 & $\begin{array}{c}\text { Phlogopite } \\
\text { Wehrlite }\end{array}$ & 51.02 & 85.0 & $\mathrm{Ol}(2), \mathrm{Cpx}(2), \mathrm{Bt}(2)$ & 80.6 & 87.0 & $6.69(0.04)$ & $6.96(0.01)$ & $7.40(0.04)$ & & & \\
\hline MO-10-392 & $\begin{array}{c}\text { Phlogopite } \\
\text { Wehrlite }\end{array}$ & 46.69 & 78.1 & $\mathrm{Ol}$ (2), $\mathrm{Cpx}(2), \mathrm{Bt}(2)$ & 74.1 & 81.0 & $7.78(0.01)$ & $8.56(0.03)$ & $8.73(0.02)$ & & & \\
\hline MO-10-323 & $\begin{array}{c}\begin{array}{c}\text { Phlogopite } \\
\text { Wehrlite }\end{array} \\
\end{array}$ & 45.76 & 77.1 & $\mathrm{Ol}(2), \mathrm{Cpx}(4)$ & 71.7 & 82.4 & $7.20(0.06)$ & $6.84(0.06)$ & & & & \\
\hline MO-11-8 & $\begin{array}{l}\text { Phlogopite } \\
\text { Wehrlite }\end{array}$ & 48.43 & 76.3 & $\mathrm{Ol}(2), \mathrm{Cpx}(2), \mathrm{Bt}(4)$ & 68.7 & 82.4 & $7.53(0.04)$ & $8.16(0.04)$ & $8.04(0.01)$ & & & \\
\hline MO-10-325 & $\begin{array}{c}\text { Phlogopite } \\
\text { Clinopyroxenite }\end{array}$ & 50.36 & 80.1 & $\mathrm{Cpx}(2), \mathrm{Bt}(2)$ & & 84.0 & & $7.05(0.06)$ & $7.58(0.07)$ & & & \\
\hline MO-10-324 & $\begin{array}{c}\text { Phlogopite } \\
\text { Clinopyroxenite }\end{array}$ & 50.31 & 74.4 & $\mathrm{Cpx}(2), \mathrm{Bt}(4)$ & & 81.3 & & $7.73(0.01)$ & $7.65(0.06)$ & & & \\
\hline MO-11-10 & Phlogopitite & 42.71 & 73.1 & $\mathrm{Cpx}(2), \mathrm{Bt}(2)$ & & 80.4 & & $8.81(0.03)$ & $8.93(0.03)$ & & & \\
\hline MO-11-12 & Monzogabbro & 49.25 & 66.9 & $\mathrm{Cpx}(2), \mathrm{Bt}(2), \operatorname{Zrc}(16)$ & & 73.0 & & $9.15(0.04)$ & $9.44(0.05)$ & & $9.38(0.21)$ & \\
\hline MO-11-14 & Monzodiorite & 53.24 & 56.0 & $\mathrm{Bt}(2), \operatorname{Zrc}(15)$ & & & & & $8.72(0.07)$ & & $8.35(0.11)$ & \\
\hline MO-11-16 & Felsic Dike & 74.58 & 32.2 & $\operatorname{Zrc}(9,5,6)^{*}$ & & & & & & & $\begin{array}{c}8.48(0.09) ; 8.91 \\
(0.11), 9.33(0.07) \\
\end{array}$ & \\
\hline MO-11-19 & Lamprophyre & 48.69 & 67.2 & $\mathrm{Bt}(4), \operatorname{Zrc}(14)$ & & 75.3 & & & $6.98(0.07)$ & & $7.87(0.10)$ & \\
\hline MO-11-21 & Monzonite & 52.47 & 64.0 & $\mathrm{Bt}(2)$ & & 74.2 & & & $7.65(0.11)$ & $13.43(0.17)$ & & \\
\hline MO-11-23 & Monzonite & 57.80 & 51.2 & $\operatorname{Zrc}(16)$ & & & & & & & $9.09(0.12)$ & \\
\hline MO-11-26 & $\begin{array}{c}\text { Quartz } \\
\text { Monzonite }\end{array}$ & 59.75 & 50.8 & $\operatorname{Cpx}(2), \operatorname{Bt}(2), \operatorname{Zrc}(17)$ & & 64.7 & & & $8.39(0.13)$ & $14.61(0.05)$ & $9.12(0.15)$ & \\
\hline
\end{tabular}

Abbreviations: Ol (olivine), Cpx (clinopyroxene), Bt (biotite), Fsp (feldspar), Qtz (quartz), Zrc (zircon), WR (whole rock powder).

All $\delta$ " $\mathrm{O}$ values are relative to Vienna Standard Mean Ocean Water (VSMOW). $\mathrm{n}$ is the number of replicate analyses. Value in parentheses behind mineral values are $1 \sigma$ of averages. Analyses in italics indicate low calculated yields.

"Zircon analyses for MO-11-16 reported for cores, sectors zones, and oscillatory zoned rims, respectively. 
Table 4: Sr and Nd Isotope Compositions for Clinopyroxene Separates from the Dariv Igneous Complex

\begin{tabular}{|c|c|c|c|c|c|c|c|c|c|c|c|c|c|c|c|}
\hline Sample & $\begin{array}{c}\mathbf{R b} \\
(\mathbf{p p m}) \\
\end{array}$ & $2 \sigma_{\mathrm{SD}}$ & $\begin{array}{c}\mathrm{Sr} \\
(\mathbf{p p m})\end{array}$ & $2 \sigma_{\mathrm{SD}}$ & ${ }^{87} \mathrm{Rb} /{ }^{86} \mathrm{Sr}$ & $\begin{array}{c}{ }^{87} \mathrm{Sr} /{ }^{86} \mathrm{Sr} \\
\text { measured }^{\mathrm{a}}\end{array}$ & $\begin{array}{c}{ }^{87} \mathrm{Sr} /{ }^{86} \mathrm{Sr} \\
(\mathbf{t}){ }^{\mathbf{b}}\end{array}$ & $\begin{array}{c}\text { Sm } \\
(\mathbf{p p m}) \\
\end{array}$ & $2 \sigma_{S D}$ & $\begin{array}{c}\text { Nd } \\
(\mathbf{p p m})\end{array}$ & $2 \sigma_{\mathrm{SD}}$ & ${ }^{147} \mathrm{Sm} /{ }^{144} \mathrm{Nd}$ & $\begin{array}{l}{ }^{143} \mathrm{Nd} /{ }^{144} \mathrm{Nd} \\
\text { measured }^{\mathrm{a}}\end{array}$ & $\begin{array}{c}{ }^{143} \mathrm{Nd} / /^{144} \mathrm{Nd} \\
(\mathrm{t})^{\mathrm{b}}\end{array}$ & $\varepsilon_{\mathrm{Nd}}(t)^{\mathbf{b}}$ \\
\hline MO-12-21 & 0.126 & 0.007 & 134 & 3 & 0.003 & $0.705622(6)$ & 0.705603 & 1.26 & 0.07 & 4.45 & 0.14 & 0.1713 & $0.512395(30)$ & 0.511832 & -3.1 \\
\hline MO-10-394 & 0.258 & 0.010 & 120 & 3 & 0.006 & $0.705045(4)$ & 0.705000 & 2.35 & 0.08 & 8.29 & 0.15 & 0.1710 & $0.512535(22)$ & 0.511973 & -0.4 \\
\hline MO-10-323 & 0.335 & 0.014 & 114 & 4 & 0.008 & $0.705551(4)$ & 0.705490 & 4.52 & 0.25 & 15.0 & 0.4 & 0.1827 & $0.512489(13)$ & 0.511888 & -2.0 \\
\hline MO-10-392 & 0.389 & 0.015 & 89 & 3 & 0.013 & $0.706149(4)$ & 0.706059 & 4.90 & 0.15 & 15.7 & 0.5 & 0.1883 & $0.512352(16)$ & 0.511733 & -5.0 \\
\hline MO-10-324 & 2.28 & 0.06 & 182 & 4 & 0.036 & $0.705823(4)$ & 0.705564 & 7.36 & 0.21 & 26.2 & 0.8 & 0.1697 & $0.512574(12)$ & 0.512016 & 0.5 \\
\hline MO-10-325 & 2.36 & 0.04 & 170 & 3 & 0.040 & $0.70569(3)$ & 0.705403 & 6.02 & 0.16 & 20.3 & 0.5 & 0.1794 & $0.512576(13)$ & 0.511986 & -0.1 \\
\hline
\end{tabular}


Table 5: Calculated Mineral-Melt Fractionation Factors used to Calculate Equilibrium Melt

\begin{tabular}{|c|c|c|c|c|c|c|c|c|c|c|c|c|c|}
\hline \multirow[b]{2}{*}{ Sample } & \multicolumn{3}{|c|}{ Equilibrium Melt Values* } & \multicolumn{3}{|c|}{ Mineral-Melt Fractionations } & \multirow[b]{2}{*}{$\Delta_{\text {plag-melt }} * *$} & \multirow[b]{2}{*}{$\Delta_{\text {zcn-melt }}$} & \multicolumn{5}{|c|}{$\begin{array}{l}\text { Calculated Melt } \delta^{18} O(\%) \text { Values } \\
\text { from Different Minerals }\end{array}$} \\
\hline & $\mathrm{T}\left({ }^{\circ} \mathrm{C}\right)$ & $\mathrm{SiO}_{2}$ & Mg\# & $\Delta_{\text {ol-melt }}$ & $\Delta_{\text {cpx-melt }}$ & $\Delta_{\text {opx-melt }}$ & & & $\mathrm{Ol}$ & Cpx & Opx & Plag & Zcn \\
\hline B06-062 & 1184 & 50.21 & 36.6 & - & -0.31 & -0.18 & 0.18 & - & & 6.07 & 6.36 & 6.59 & \\
\hline B06-067 & 1141 & 50.27 & 29.6 & - & -0.34 & -0.22 & 0.23 & - & & 6.10 & 6.30 & 6.42 & \\
\hline B07-057 & 1114 & 52.44 & 27.5 & - & -0.43 & -0.32 & 0.20 & - & & 6.39 & 6.48 & 6.95 & \\
\hline B06-024 & 1065.0 & 55.75 & 24.4 & -1.09 & - & - & 0.11 & - & 6.51 & & & 6.90 & \\
\hline B06-029 & 1004.0 & 63.39 & 17.4 & -1.45 & - & - & -0.07 & - & 6.81 & & & 6.99 & \\
\hline B07-027 & 991.0 & 66.29 & 15.0 & - & - & - & -0.17 & - & & & & 7.04 & \\
\hline B06-055 & 974.0 & 68.92 & 12.9 & - & - & - & -0.27 & - & & & & 7.07 & \\
\hline В07-038 & 950.0 & 72.38 & 4.4 & -1.93 & - & - & -0.44 & - & 7.14 & & & 7.28 & \\
\hline B07-041 & 938.0 & 73.86 & 0.6 & - & - & - & -0.46 & - & & & & 7.31 & \\
\hline MO-12-21 & 1200 & 50.20 & 73.9 & -0.60 & -0.18 & - & - & - & 7.12 & 7.34 & & & \\
\hline MO-10-396 & 1200 & 50.20 & 73.0 & -0.60 & -0.18 & - & - & - & 7.34 & 7.25 & & & \\
\hline MO-10-394 & 1136 & 50.36 & 63.7 & -0.87 & -0.41 & - & - & - & 7.57 & 7.83 & & & \\
\hline MO-10-392 & 1019 & 60.64 & 50.1 & -1.45 & -0.90 & - & - & - & 9.22 & 10.01 & & & \\
\hline MO-10-323 & 1094 & 52.30 & 57.7 & -1.00 & -0.51 & - & - & - & 8.20 & 7.84 & & & \\
\hline MO-11-8 & 1102 & 51.18 & 58.6 & -0.95 & -0.46 & - & - & - & 8.48 & 9.11 & & & \\
\hline MO-10-325 & 1060 & 57.82 & 54.7 & - & -0.75 & - & - & - & & 8.31 & & & \\
\hline MO-10-324 & 1017 & 60.69 & 49.9 & - & -0.90 & - & - & - & & 9.18 & & & \\
\hline MO-11-10 & 1006 & 61.11 & 48.6 & - & -0.94 & - & - & - & & 10.31 & & & \\
\hline MO-11-12 & 950 & 61.81 & 41.1 & - & -1.07 & - & - & -1.0 & & 10.84 & & & 10.4 \\
\hline MO-11-14 & 1080 & 54.49 & 56.04 & - & - & - & - & -0.4 & & & & & 8.8 \\
\hline MO-11-16 & 760 & 75.01 & 32.21 & - & - & - & - & -1.8 & & & & & 11.1 \\
\hline MO-11-19 & 1200 & 49.83 & 67.24 & - & - & - & - & -0.2 & & & & & 8.1 \\
\hline MO-11-23 & 1055 & 58.78 & 51.24 & - & - & - & - & -0.7 & & & & & 9.8 \\
\hline MO-11-26 & 1025 & 60.61 & 51.63 & - & - & - & - & -0.7 & & & & & 9.8 \\
\hline
\end{tabular}

*Equilibrium melt temperatures and compositions for Bushveld Complex are based on MELTS modeling calculations and for Dariv Igneous Complex based on

comparison to experimental glasses of Righter \& Carmichael, 1996. **Bulk plagioclase fractionation taking into consideration albite-anorthite solid solution.

Italicized equilibrium melt values are for "liquid-like" samples in that $\mathrm{SiO}_{2}$ is the whole rock value. 
Table 6: Summary of Model Results (Melt $\delta^{18} \mathrm{O}$, Temperature, $\mathrm{SiO}_{2}$, and Mg\#)

\begin{tabular}{|c|c|c|c|c|c|c|c|c|c|c|c|c|}
\hline \multirow{2}{*}{$\frac{\text { LLD }}{\mathrm{F}}$} & \multicolumn{4}{|c|}{$\begin{array}{l}\text { Villiger et al. }(2004) \\
\text { Anhydrou tholeiite, } 1.0 \mathrm{GPa}\end{array}$} & \multicolumn{4}{|c|}{$\begin{array}{l}\text { Whitaker et al. (2008) } \\
0.4 \text { wt. } \% \mathrm{H}_{2} \mathrm{O} \text { olivine tholeiite, } 0.4 \mathrm{GPa}\end{array}$} & \multicolumn{4}{|c|}{$\begin{array}{l}\text { Nandekhar et al. (2014) } \\
\text { Hydrous tholeiite, } 0.7 \mathrm{GPa}\end{array}$} \\
\hline & $\begin{array}{l}\delta^{18} \mathrm{O} \% \text { } \\
\text { Increase }\end{array}$ & $\begin{array}{c}\mathrm{T} \\
\left({ }^{\circ} \mathrm{C}\right)\end{array}$ & $\begin{array}{c}\mathrm{SiO}_{2} \\
(\text { wt. \%) }\end{array}$ & Mg\# & $\begin{array}{c}\delta^{18} \mathrm{O} \% 0 \\
\text { Increase }\end{array}$ & $\mathrm{T}\left({ }^{\circ} \mathrm{C}\right)$ & $\begin{array}{l}\mathrm{SiO}_{2}^{*} \\
(\mathrm{wt} . \%)\end{array}$ & Mg\# & $\begin{array}{l}\delta^{18} \mathrm{O} \% 0 \\
\text { Increase }\end{array}$ & $\mathrm{T}\left({ }^{\circ} \mathrm{C}\right)$ & $\begin{array}{l}\mathrm{SiO}_{2}^{*} \\
(\mathrm{wt} . \%)\end{array}$ & Mg\# \\
\hline 1.0 & 0.000 & 1330 & 49.85 & 78.3 & 0.000 & 1283 & 47.53 & 67.6 & 0.000 & 1170 & 47.68 & 67.4 \\
\hline 0.9 & 0.050 & 1276 & 50.55 & 76.9 & 0.060 & 1198 & 47.71 & 61.1 & 0.040 & 1095 & 47.31 & 63.0 \\
\hline 0.8 & 0.099 & 1259 & 50.99 & 73.3 & 0.111 & 1187 & 47.91 & 58.7 & 0.078 & 1071 & 47.28 & 60.8 \\
\hline 0.7 & 0.140 & 1245 & 51.40 & 68.9 & 0.136 & 1176 & 47.87 & 56.2 & 0.132 & 1050 & 48.30 & 56.6 \\
\hline 0.6 & 0.173 & 1231 & 51.81 & 64.9 & 0.152 & 1163 & 47.29 & 53.6 & 0.215 & 1040 & 50.01 & 52.4 \\
\hline 0.5 & 0.209 & 1217 & 52.23 & 61.3 & 0.167 & 1149 & 46.75 & 51.2 & 0.324 & 1020 & 51.07 & 45.7 \\
\hline 0.4 & 0.256 & 1192 & 52.99 & 57.6 & 0.186 & 1132 & 46.77 & 48.4 & 0.456 & 974 & 55.30 & 51.5 \\
\hline 0.3 & 0.325 & 1152 & 56.53 & 42.0 & 0.223 & 1113 & 47.45 & 44.7 & 0.653 & 905 & 60.17 & 51.3 \\
\hline 0.2 & 0.459 & 1131 & 60.56 & 31.9 & 0.266 & 1100 & 47.72 & 41.1 & 1.044 & 743 & 67.16 & 52.4 \\
\hline 0.1 & 0.872 & 1082 & 65.56 & 18.6 & 0.444 & 1027 & 52.07 & 28.0 & - & - & - & - \\
\hline
\end{tabular}

\begin{tabular}{|c|c|c|c|c|c|c|c|c|c|c|c|c|}
\hline LLD & \multicolumn{3}{|c|}{$\begin{array}{l}\text { Jagoutz (2010)- Kohistan Arc } \\
\text { Hydrous, calc-alkaline basalt }\end{array}$} & & \multicolumn{4}{|c|}{$\begin{array}{l}\text { VanTongeren et al. (2011 UUMZ, Bushveld } \\
1 \text { wt. } \% \mathrm{H}_{2} \mathrm{O} \text { basalt, } 0.2 \mathrm{GPa}\end{array}$} & \multicolumn{4}{|c|}{$\begin{array}{l}\text { Bucholz et al., }(2014 b) \text { - Dariv Igneous Complex } \\
\text { High-K, hydrous basalt }\end{array}$} \\
\hline $\mathrm{F}$ & $\begin{array}{l}\delta^{18} \mathrm{O} \% 0 \\
\text { Increase }\end{array}$ & $\overline{\mathrm{T}\left({ }^{\circ} \mathrm{C}\right)}$ & $\begin{array}{c}\mathrm{SiO}_{2} \\
(\text { wt. } \%)\end{array}$ & Mg\# & $\begin{array}{l}\delta^{18} \mathrm{O} \% 0 \\
\text { Increase }\end{array}$ & $\mathrm{T}\left({ }^{\circ} \mathrm{C}\right)$ & $\begin{array}{l}\mathrm{SiO}_{2} \\
\text { (wt.\%) }\end{array}$ & Mg\# & $\begin{array}{l}\delta^{18} \mathrm{O} \% 0 \\
\text { Increase }\end{array}$ & $\overline{\mathrm{T}\left({ }^{\circ} \mathrm{C}\right)}$ & $\begin{array}{c}\mathrm{SiO}_{2} \\
\text { (wt.\%) }\end{array}$ & Mg\# \\
\hline 1.0 & 0.000 & 1137 & 50.72 & 69.3 & 0.000 & 1200 & 50.83 & 40.8 & 0.000 & 1150 & 52.00 & 71.9 \\
\hline 0.9 & 0.057 & 1080 & 51.44 & 61.6 & 0.006 & 1172 & 50.77 & 34.2 & 0.064 & 1095 & 52.56 & 66.9 \\
\hline 0.8 & 0.107 & 1041 & 51.62 & 54.4 & 0.010 & 1141 & 50.90 & 29.7 & 0.137 & 1062 & 53.28 & 63.5 \\
\hline 0.7 & 0.182 & 1023 & 52.94 & 51.0 & 0.020 & 1119 & 53.02 & 27.8 & 0.202 & 1020 & 54.47 & 59.9 \\
\hline 0.6 & 0.264 & 1006 & 54.20 & 50.7 & 0.041 & 1090 & 55.03 & 25.9 & 0.272 & 994 & 55.28 & 57.6 \\
\hline 0.5 & 0.368 & 987 & 55.87 & 50.2 & 0.097 & 1056 & 58.13 & 23.3 & 0.364 & 966 & 56.28 & 54.2 \\
\hline 0.4 & 0.471 & 962 & 57.07 & 49.6 & 0.211 & 1027 & 61.80 & 19.9 & 0.479 & 950 & 57.48 & 52.8 \\
\hline 0.3 & 0.613 & 931 & 58.53 & 48.6 & 0.408 & 995 & 67.63 & 15.6 & 0.635 & 933 & 58.98 & 52.0 \\
\hline 0.2 & 0.853 & 889 & 61.40 & 46.2 & 0.767 & 957 & 71.41 & 6.1 & 0.869 & 907 & 61.31 & 51.5 \\
\hline 0.1 & 1.529 & 670 & 69.73 & 25.6 & - & - & - & - & 1.463 & 787 & 68.08 & 47.8 \\
\hline
\end{tabular}

$\mathrm{SiO}_{2}$ values are normalized to an anhydrous total unless noted with a *. 


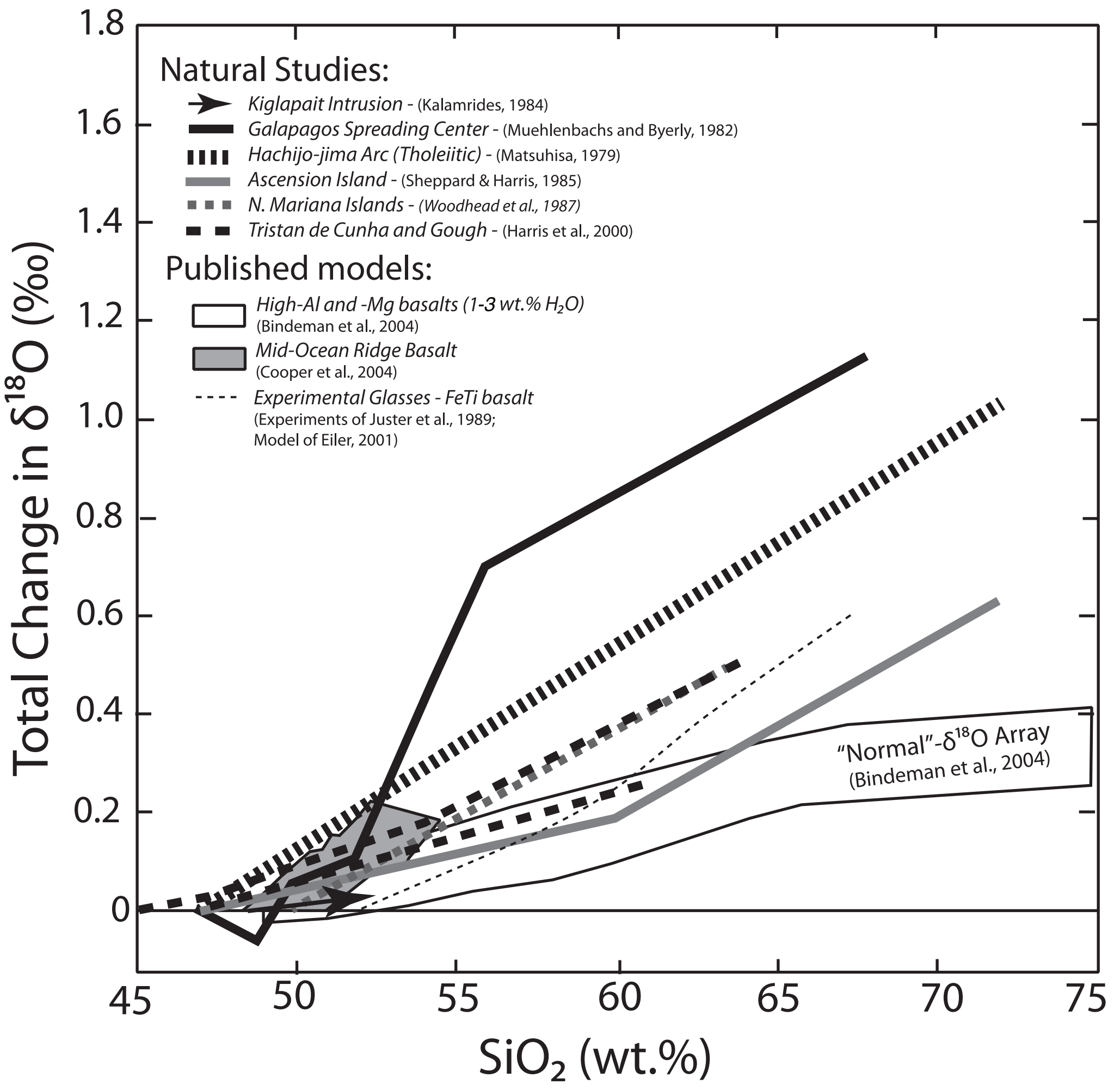




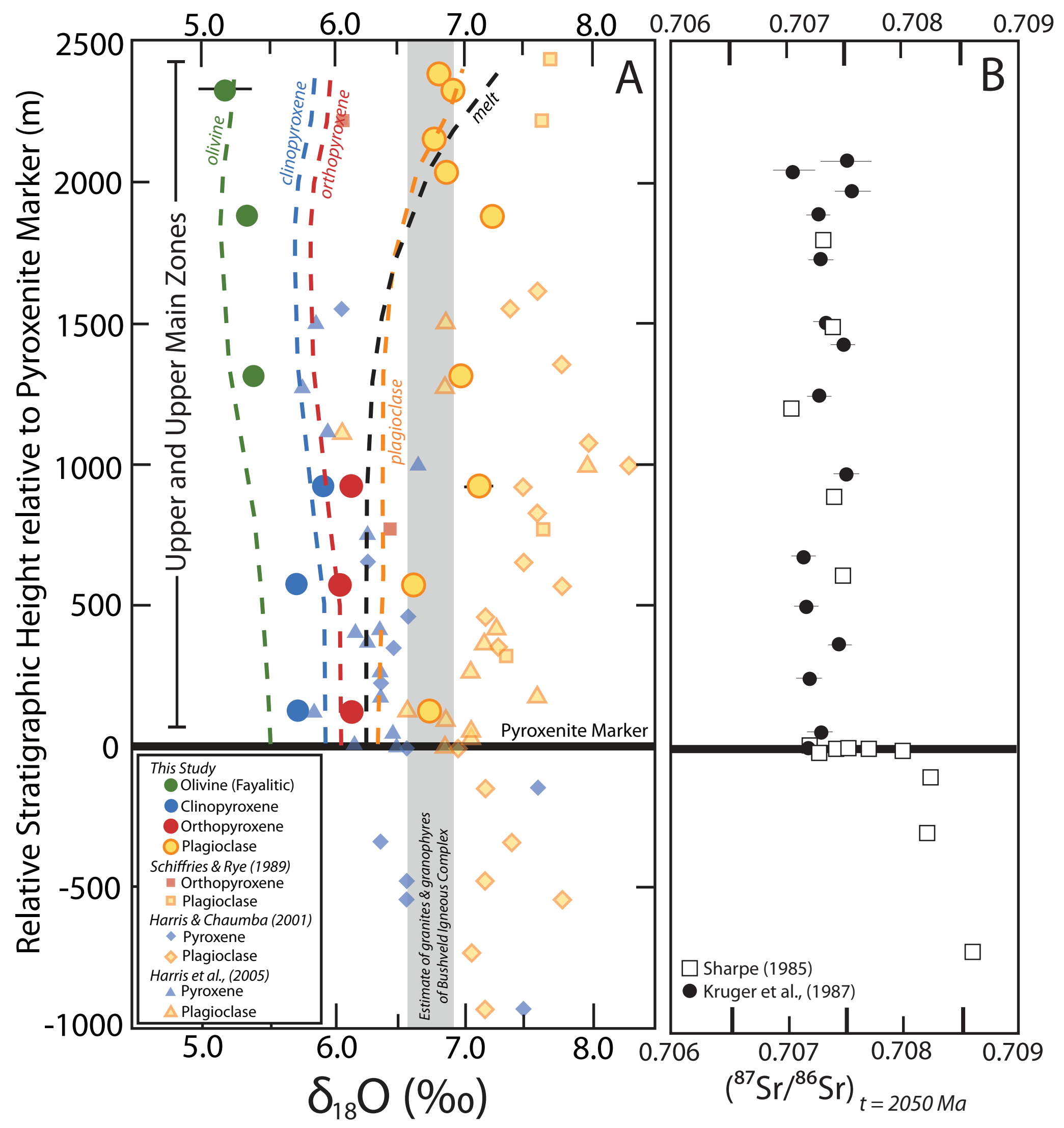


Figure 3

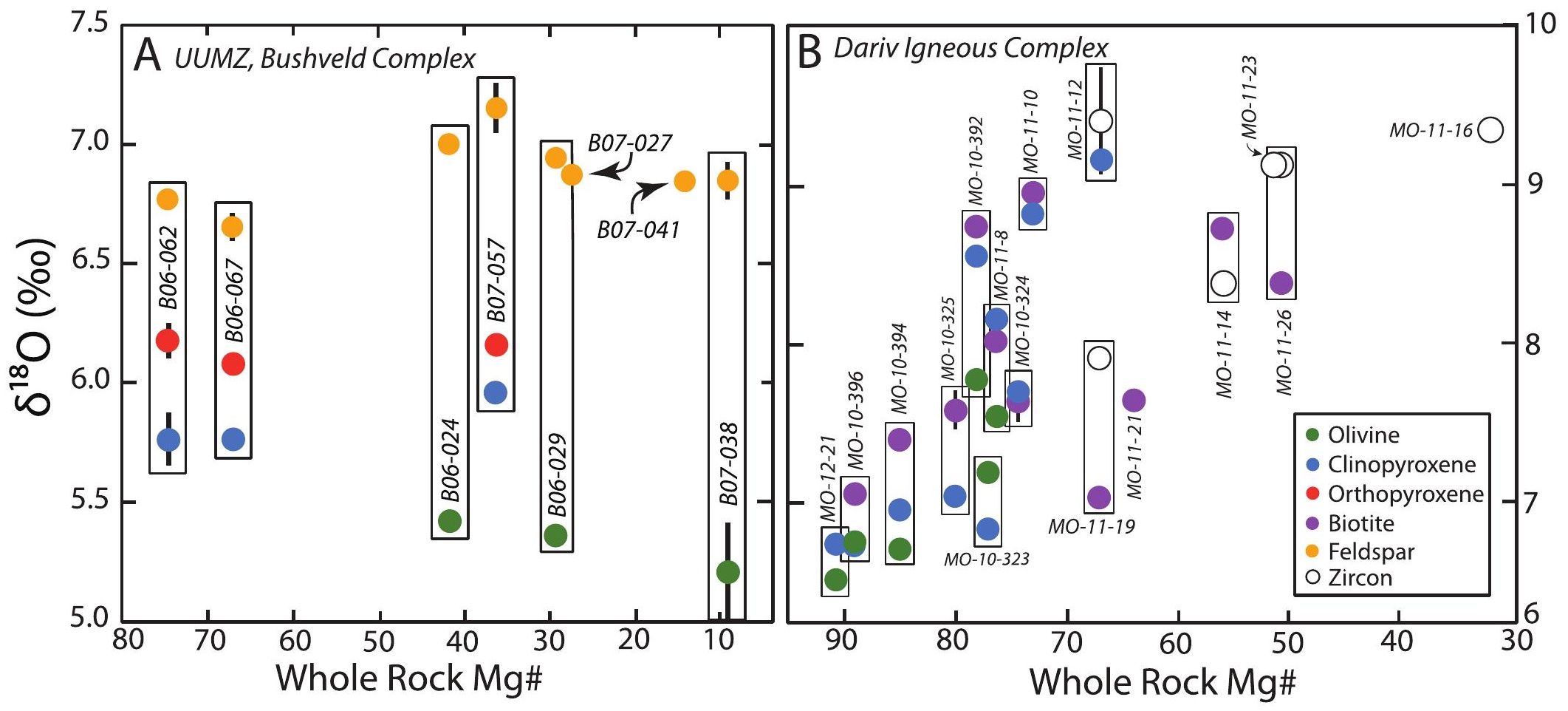


Figure 4

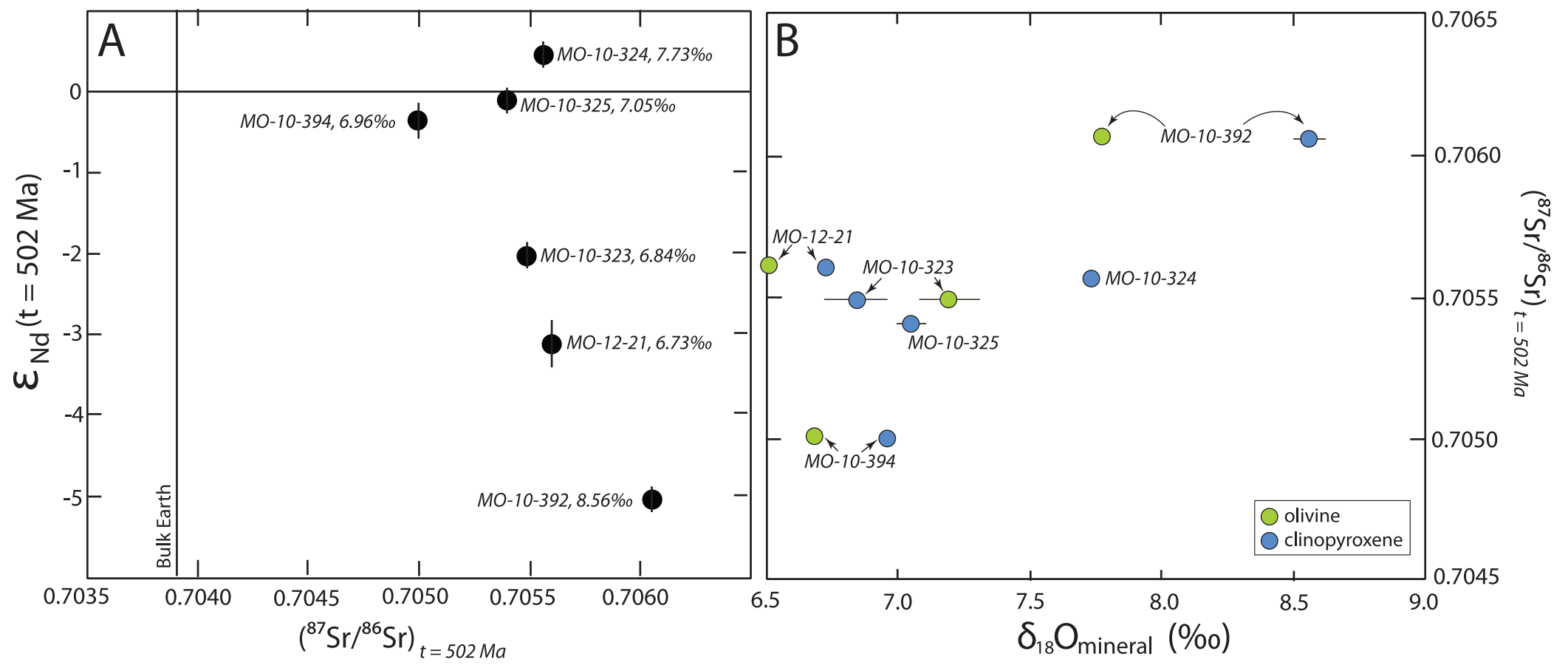



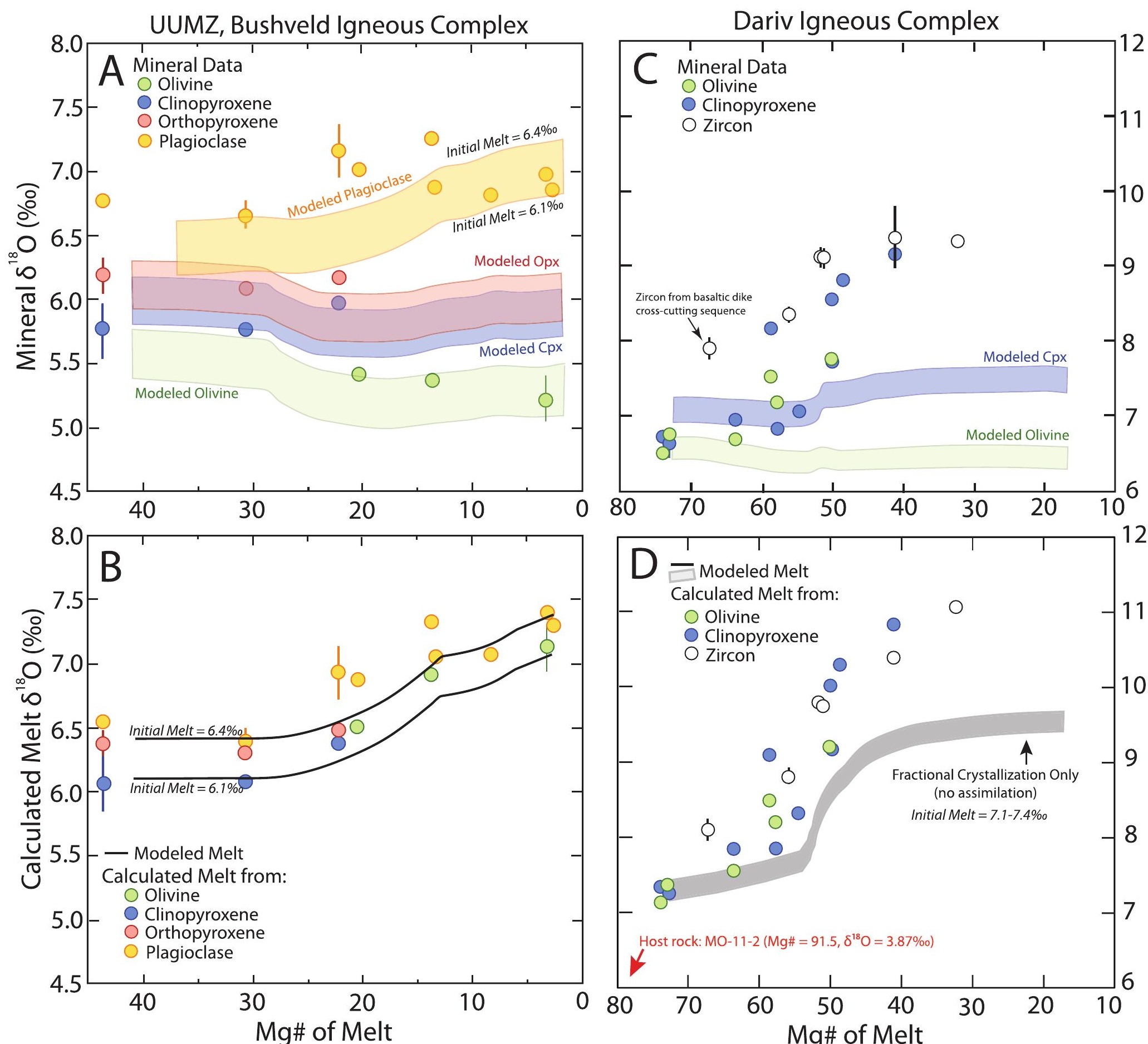
Figure 80
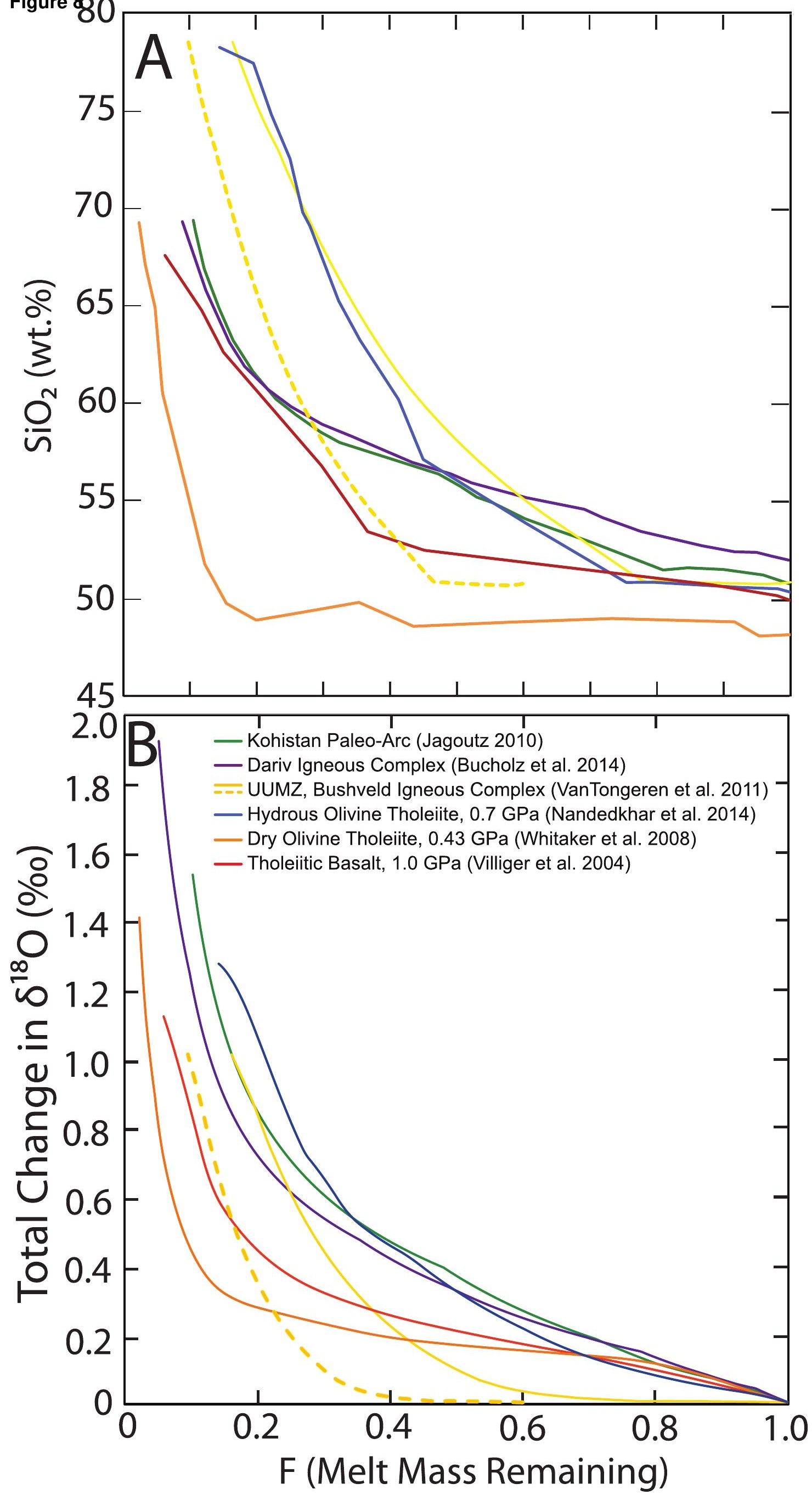


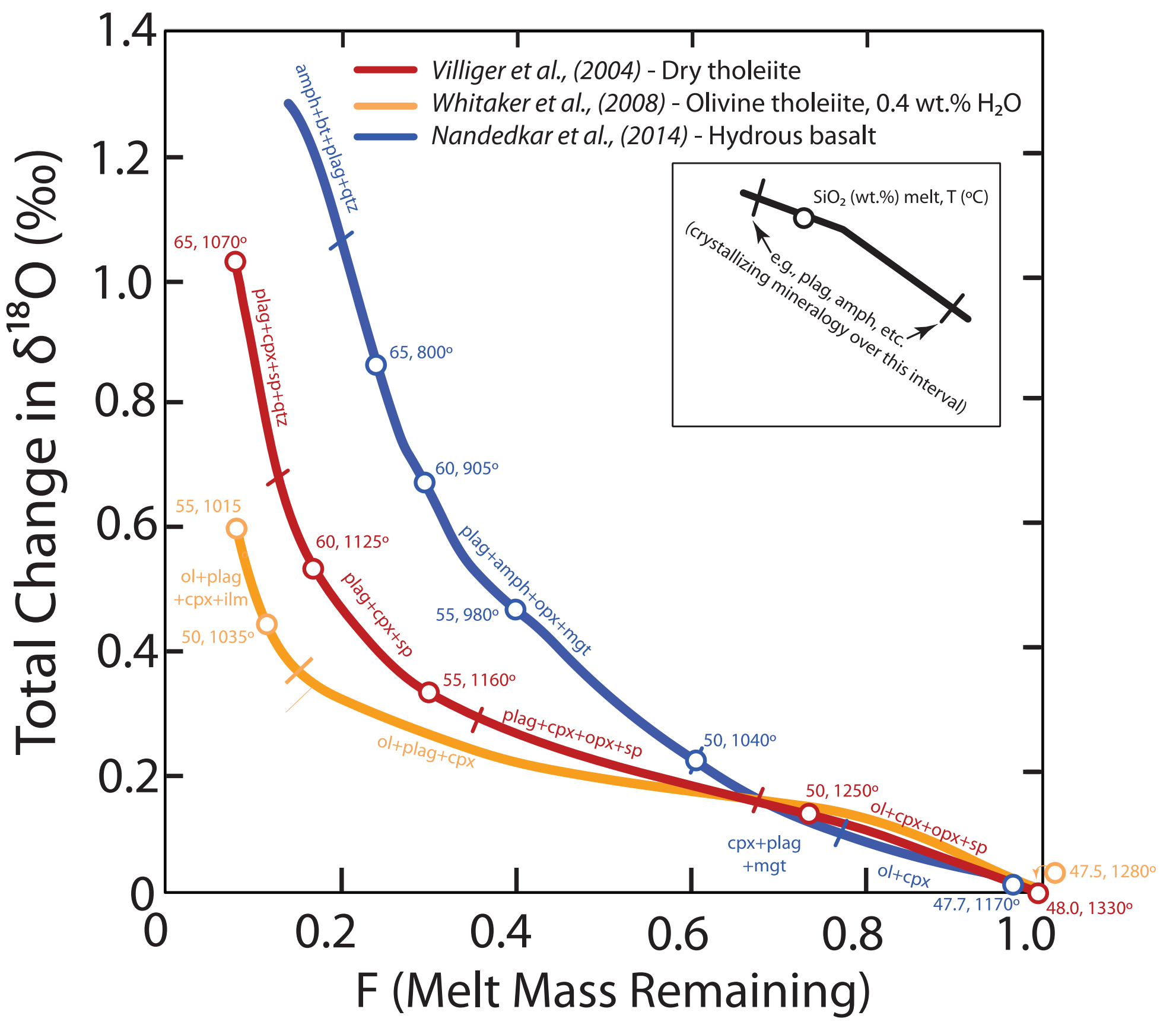



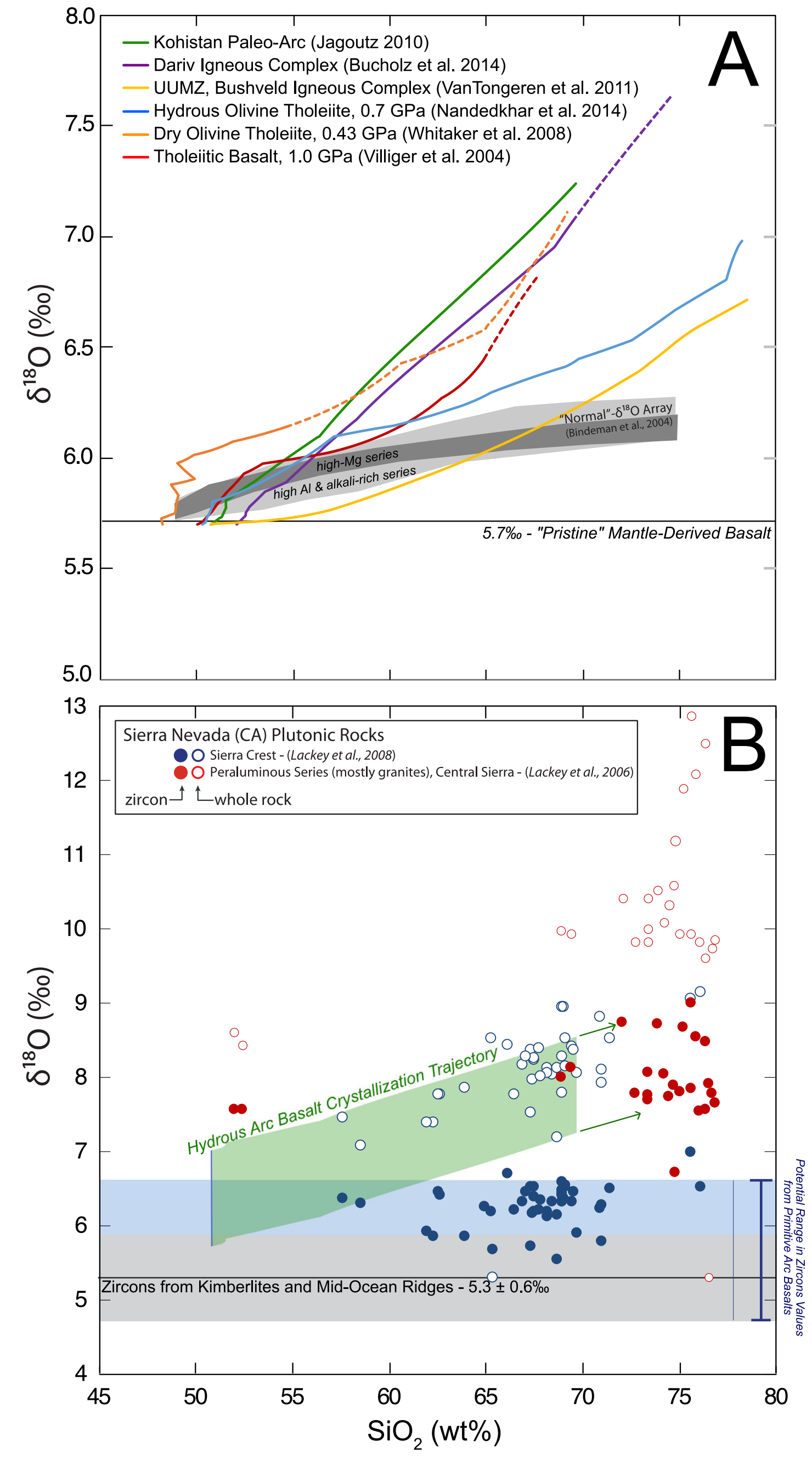

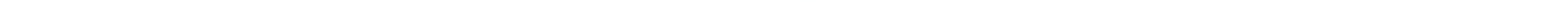